\title{
EFFECTS OF SUDANGRASS COVER CROP AND SOIL SOLARIZATION ON WEED AND PATHOGEN MANAGEMENT IN ORGANIC STRAWBERRY PRODUCTION
}

\author{
A Thesis \\ presented to \\ the Faculty of California Polytechnic State University, \\ San Luis Obispo
}

\begin{abstract}
In Partial Fulfillment
of the Requirements for the Degree

Master of Science in Agriculture with a Concentration in Plant Protection Science
\end{abstract}

by

Timothy Jacobs

August 2019 
(C) 2019

Timothy Jacobs

ALL RIGHTS RESERVED 


\title{
COMMITTEE MEMBERSHIP
}

\author{
TITLE: Effects of Sudangrass Cover Crop and Soil \\ Solarization on Weed and Pathogen Management in \\ Organic Strawberry Production
}

AUTHOR: Timothy Jacobs

DATE SUBMITTED: August 2019

COMMITTEE CHAIR: Ashraf Tubeileh, Ph.D.

Assistant Professor of Horticulture and Crop Science

COMMITTEE MEMBER: Scott Steinmaus, Ph.D.

Department Head of Horticulture and Crop Science

COMMITTEE MEMBER: Gerald Holmes, Ph.D.

Director, Strawberry Center 


\begin{abstract}
Effects of Sudangrass Cover Crop and Soil Solarization on Weed and Pathogen Management in Organic Strawberry Production
\end{abstract}

Timothy Jacobs

Field and lab experiments were conducted to determine the efficacy of sudangrass (Sorghum X drumondii (Nees ex Steud.) Millsp. \& Chase) cover crop management techniques and soil solarization on important agricultural weeds and pathogens in organic strawberry production in Central California. Lab experiments assessed the time needed to kill weed seeds at temperatures typically achieved during soil solarization $\left(40^{\circ} \mathrm{C}, 45^{\circ} \mathrm{C}\right.$, $50^{\circ} \mathrm{C}, 55^{\circ} \mathrm{C}$, and $60^{\circ} \mathrm{C}$ ) in California. Seeds tested included little mallow, redstem filaree, bristly oxtongue, annual sowthistle, common purslane, nettleleaf goosefoot, and redroot pigweed. Efficacy of simulated solarization temperatures differed between different species. Cool-season annuals annual sowthistle and bristly oxtongue were more susceptible to heat treatments than warm-season annuals common purslane, redroot pigweed and nettleleaf goosefoot. Hard seeded weed species little mallow and redstem filaree were the least susceptible to heat treatments. Annual sowthistle, bristly oxtongue and nettleleaf goosefoot were affected at all temperatures. Redroot pigweed and little mallow were not affected by temperatures below $40^{\circ} \mathrm{C}$. Common purslane was not affected by temperature below $45^{\circ} \mathrm{C}$ and redstem filaree was not affect by any temperatures tested. Hours of exposure and percent mortality of weed seeds were used to create thermal death models for weed seeds. Field experiments were conducted at the Cal Poly Organic Farm in San Luis Obispo, CA testing the effects of soil solarization and 
sudangrass residues on weeds, Verticillium dahliae populations, plant health, and yields in organic strawberry production. Using a split plot design, sudangrass was grown, mowed and then developed into two treatments: surface mulch or incorporated into the soil. The sudangrass treatments and a control were tested with and without soil solarization $(n=4)$. Maximum soil temperatures in solarized treatments were $53^{\circ} \mathrm{C}$ at a soil depth of $5 \mathrm{~cm}$ and $42^{\circ} \mathrm{C}$ at a soil depth of $15 \mathrm{~cm}$. Solarization reduced weed biomass between 49.8 and $95.2 \%$ during the first 3.5 months after tarp removal $(p=0.03)$, reduced Verticillium dahliae populations by $80.7 \%(p=0.01)$, reduced plant mortality by $54.9 \%$ $(<0.01)$, and roughly tripled yields compared to non-solarized treatments $(p<0.01)$. Sudangrass treatments did not affect $V$. dahliae populations $(p=0.33)$ or yields $(p=0.25)$. However, mulched treatments reduced weed biomass between 45.0 and $61.3 \%(p=0.03)$ compared to other sudangrass treatments. Results indicate solarization can be used in central coast organic strawberry production to reduce hand-weeding, disease incidence, and increase yields.

Keywords: Strawberries, weeds, pathogens, Verticillium dahliae, solarization, biosolarization, sudangrass, organic farming 


\section{ACKNOWLEDGMENTS}

Thank you to everyone who offered support, guidance and funding for my master's thesis. Special thanks to Dr. Ashraf Tubeileh, my major advisor, for his guidance and support throughout the entire project. From writing the initial grant proposal through the final edits of the thesis Dr. Tubeileh was instrumental in guiding this project and without his support this master's thesis would not have been possible.

Additionally, I would like to thank my committee members Dr. Scott Steinmaus and Dr. Gerald Holmes for their technical assistance with the thesis and insightful comment/edits to the thesis.

I would like to thank the Cal Poly Strawberry Center for providing plants, plastic, and other assistance with the field research. In addition to Dr. Holmes, I would like to thank Dr. Mojtaba Mansouripour for his help with pathogen identification and pathology techniques.

Also, special thanks to the staff of the Cal Poly Organic Farm for assistance with field preparation and space for conducting research, I would like to thank Gregg Cady and Dan Chesini for their help with the farm equipment operation.

I would also like to thank the undergraduate assistants who helped with this project, particularly Adam Tassinari and Jon Skrbina.

Furthermore, I would like to thank Jim and Dr. Wyatt Brown for allowing us to use the post-harvest lab and the lab equipment it contains. 
I would also like to acknowledge the Cal Poly Horticulture and Crop Science Department, Annie's Sustainable Agriculture Scholars program, and the Organic Farming Research Foundation for funding my research and studies.

Lastly, I would like to thank my friends and family for their support and encouragement throughout my master's program. Without your support pursuing this degree would not have been possible. Special thanks to Hana for helping me design and listening to all my presentations. 


\section{TABLE OF CONTENTS}

\section{Page}

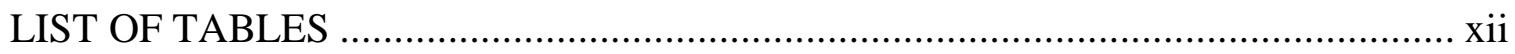

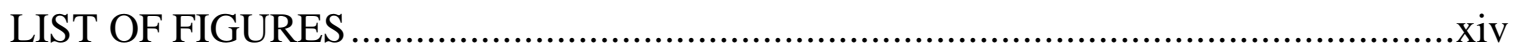

\section{CHAPTER}

\section{INTRODUCTION AND LITERATURE REVIEW ..............................................}

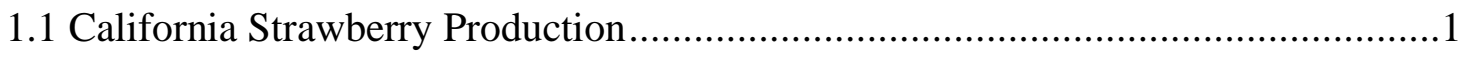

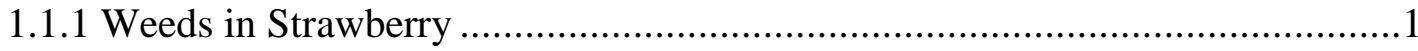

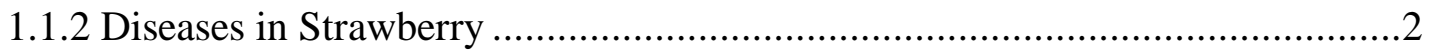

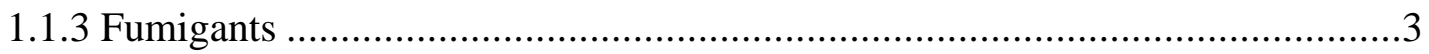

1.2 Alternatives to Soil Fumigation for Soil Disinfestation...................................

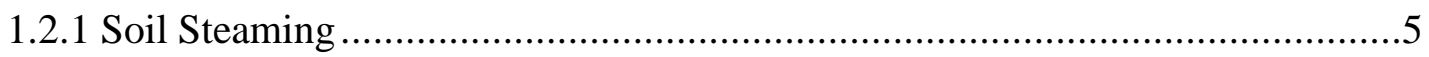

1.2.1.1 Steaming in Strawberry Production ................................................6

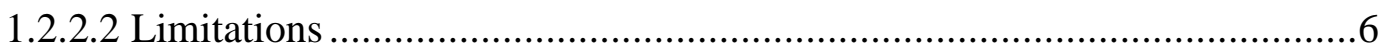

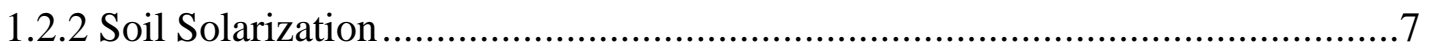

1.2.2.1 Weed Management ....................................................................

1.2.2.2 Pathogen Management..........................................................

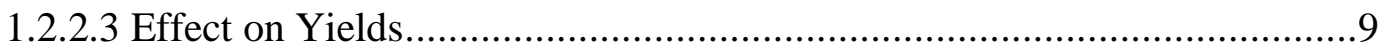

1.2.2.4Solarization in Strawberries ......................................................... 10

1.2.3 Biofumigants and Other Organic Amendments.................................... 11

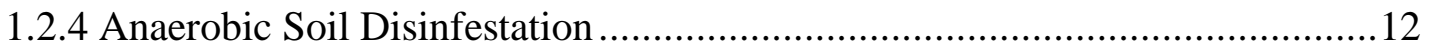

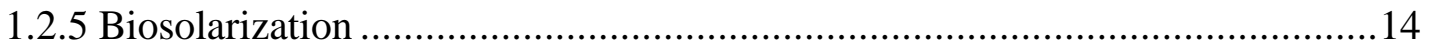

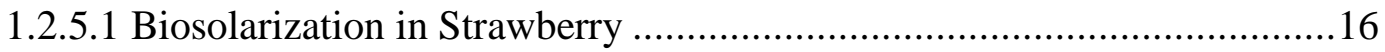


1.2.6 Biofumigation Potential of Sorghum spp. ...............................................17

1.2.6.1 Biosolarization of Sudangrass............................................................ 19

2. LOGISTIC REGRESSION MODELS OF IMPORTANT WEED SPECIES

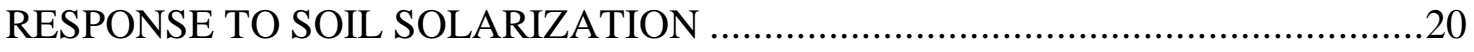

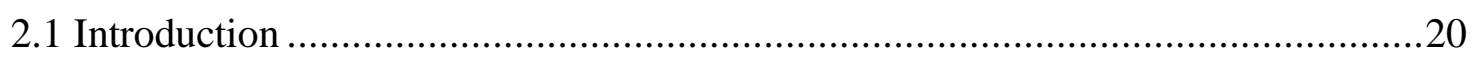

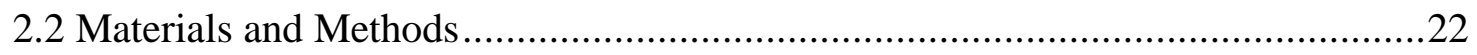

2.2.1 Seed Collection and Preparation .............................................................22

2.2.2 Thermal Treatments ………….............................................................23

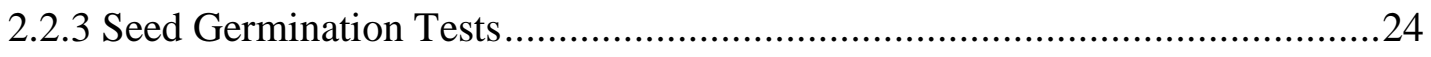

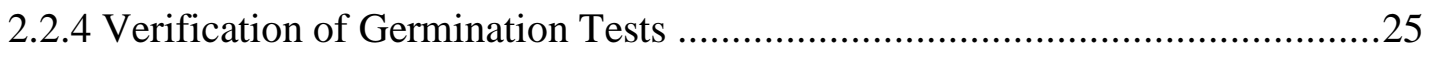

2.2.5 Statistical Analysis ..............................................................................26

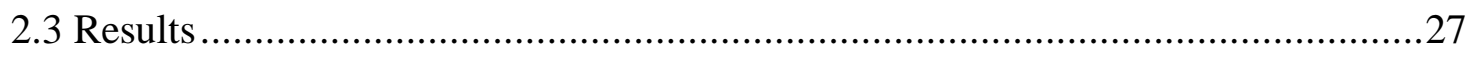

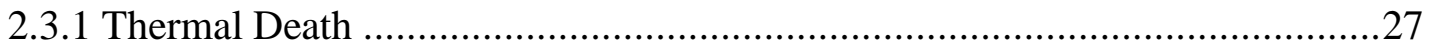

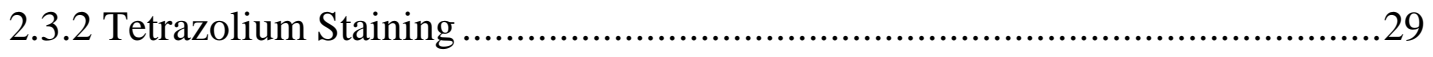

2.3.3 Logistic Regression Models........................................................................

2.4 Application to Field Conditions ……..............................................................

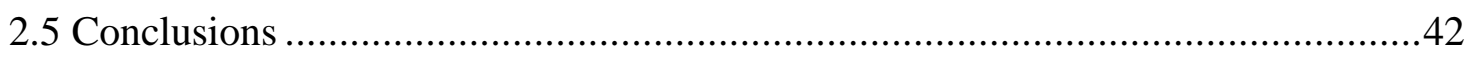

3. EFFECT OF SUDANGRASS COVER CROP RESIDUES AND SOIL SOLARIZATION ON WEED AND PATHOGEN POPULATIONS IN ORGANIC

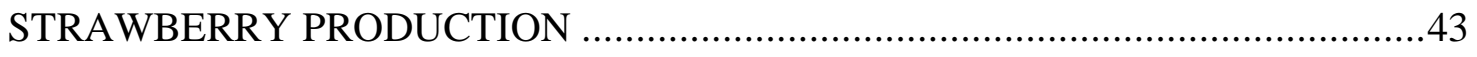

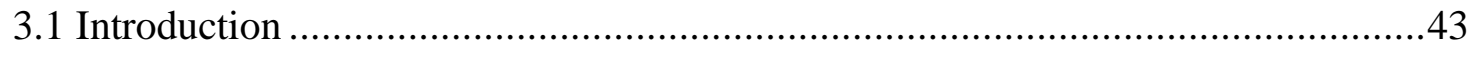

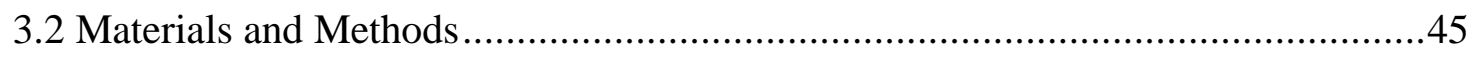

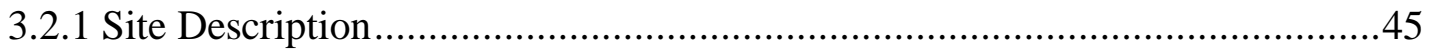




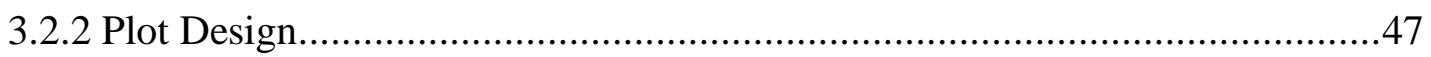

3.2.3 Cover Crop Planting ...............................................................................

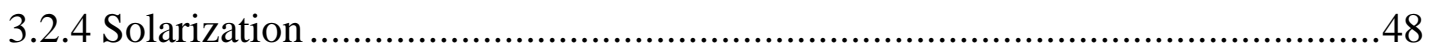

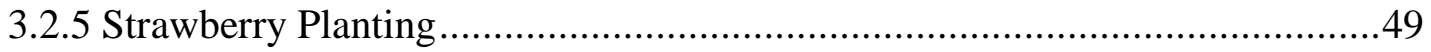

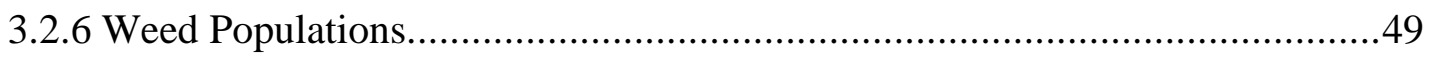

3.2.7 Verticillium dahliae Inoculum Density ........................................................50

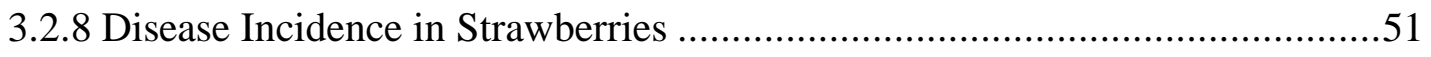

3.2.9 Strawberry Health and Yields ................................................................52

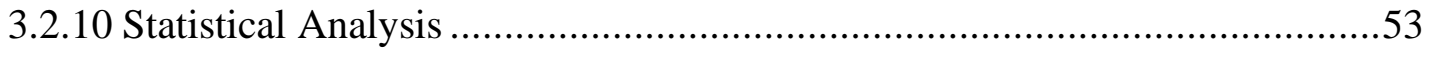

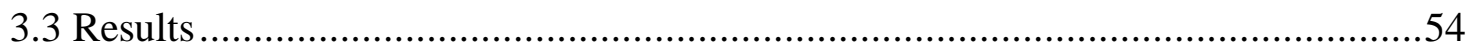

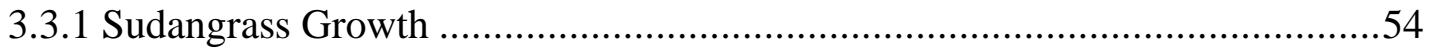

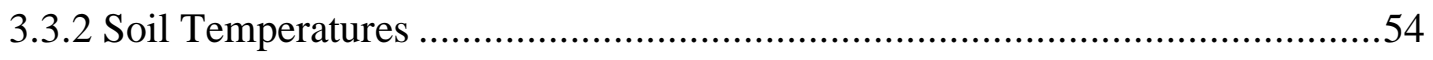

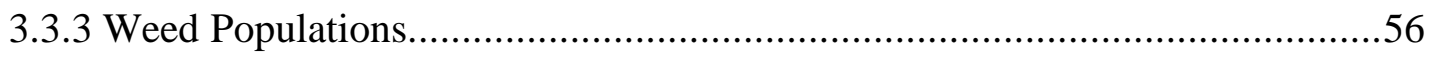

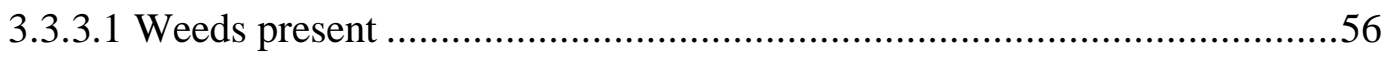

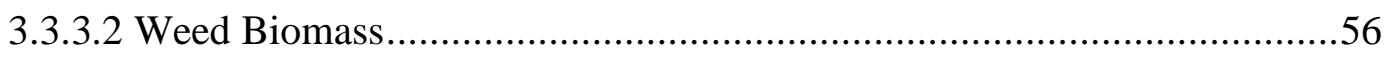

3.3.3.3 Relative Species Cover .....................................................................58

3.3.4 Verticillium dahliae Populations..................................................................6

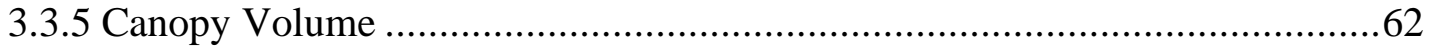

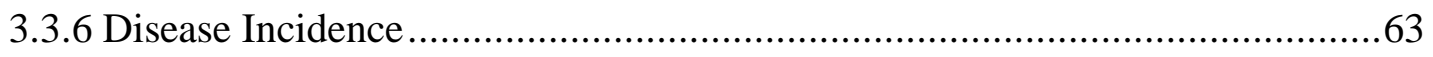

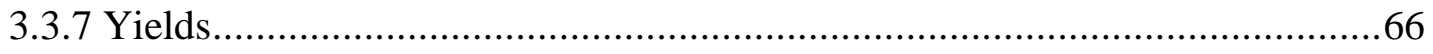

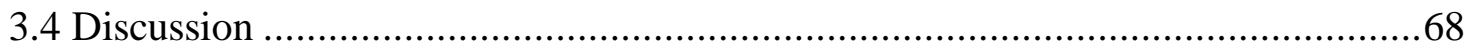

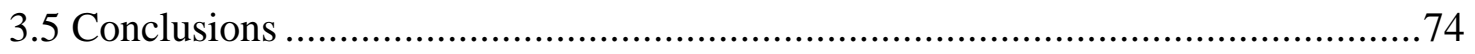

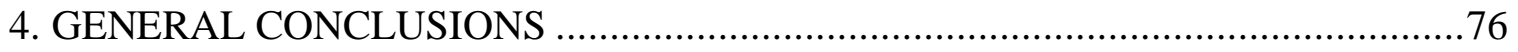


REFERENCES.

\section{APPENDICES}

A. Research design and field information.. 


\section{LIST OF TABLES}

Table

Page

1.1: Lethal Soil Temperatures and Durations for Management Of Soilborne Pests in Soil Steaming Applications Under Moist Conditions. 6

2.1: List of Weed Species Tested Divided Into Three Categories .....

2.2: Species and Temperatures Where a Significant Decrease in Germination Rate was Not Observed.

2.3: Number of Hours at All Temperatures Tested Required for 0\% Germination of Different Weed Seeds.

2.4: Percentage of Viable Seeds at Each Temperature Treatment After Undergoing Tetrazolium Staining. 30

2.5: Time (Hours) Required for 50\% Mortality (LD50) and 90\% Mortality (LD90) According to Logistic Regression Models. .38

3.1: Soil Properties and Cation Exchange Properties Taken on 21 May on the Cal

Poly Organic Farm.

3.2: Average Maximum Temperatures, Maximum Temperature Achieved (Not Averaged), and Average Number of Hours Where Temperature Was Above $40^{\circ} \mathrm{C}$ and $45^{\circ} \mathrm{C}$ at a Depth of $5 \mathrm{~cm}$ And $15 \mathrm{~cm}$. .55

3.3: Weed Biomass $\left(\mathrm{g} / \mathrm{m}^{2}\right)$ and Weed Density (Number/M $\mathrm{M}^{2}$ ) Measurements Taken 1.5 Months (Oct.), 2.5 Months (Nov.), and 3.5 Months (Dec.) After Tarp Removal.

3.4: Relative Ground Cover of Prominent Weed Species in Weedy Checks 1.5 Months After Tarp Removal (13 Oct), 2.5 Months After Tarp Removal (9 
Nov) and 3.5 Months After Tarp Removal (12 Dec) Between Solarized and Non-Solarized Treatments

3.5: Interaction Effect of Sudangrass and Solarization Treatments of Total Weed Cover (\%) in Weedy Checks Taken 1.5 Months, 2.5 Months, and 3.5 Months After Tarp Removal.

3.6: Disease Incidence (\% of Total Infected Plants) and Plant Mortality (\% of Dead Plants) Measurements Recorded at the End of Harvest (June $28^{\text {th }}$ ) for

Sudangrass and Solarization Treatments. .66

3.7: Marketable Yield per 30 Plants (g), ${ }^{\circ}$ Brix (\% Sugar Content), and Average

Weight of Marketable Fruit for Sudangrass and Solarization Treatments.

A.1:Weather Data from CIMIS Station 52 Located on Cal Poly San Luis Obispo

Campus from May 2018 to June 2019. 


\section{LIST OF FIGURES}

Figure

Page

1.1: Ratio (\%) of Yields on Solarized Fields Compared to Untreated/Control Fields in a Variety of Vegetable Crops and Berry Crops (Lettuce, Potato, Strawberry, Carrot, Eggplant, Artichoke, and Beans) And Their Respective Locations..

2.1: Examples of Two Nettleleaf Goosefoot Seeds, One Viable (Left) and One Non-Viable (Right) Soaked in 1\% (Wt/Vol) Tetrazolium Solution for 24

Hours. .26

2.2: Treatment and Control Germination Rates \pm Standard Error (\%) for Redstem Filaree for Experiments at the Longest Time Tested at $40^{\circ} \mathrm{C}(\mathrm{Blue}), 45^{\circ} \mathrm{C}$ (Red), $50^{\circ} \mathrm{C}\left(\right.$ Green), $55^{\circ} \mathrm{C}$ (Purple) and $60^{\circ} \mathrm{C}$ (Orange). .28

2.3: Logistic Regression Models, $\mathrm{G}_{\mathrm{t}}=1-\left(1 /\left(1+\mathrm{e}^{\mathrm{b} 0-\mathrm{b} 1 * \mathrm{~h}}\right)\right)$ of Bristly Oxtongue at $40^{\circ} \mathrm{C}$ (Blue), $45^{\circ} \mathrm{C}($ Red $), 50^{\circ} \mathrm{C}$ (Green), And $55^{\circ} \mathrm{C}$ (Purple)........

2.4: Logistic Regression Models, $\mathrm{G}_{\mathrm{t}}=1-\left(1 /\left(1+\mathrm{e}^{\mathrm{b} 0-\mathrm{b} 1 * \mathrm{~h}}\right)\right)$ of Annual Sowthistle at $40^{\circ} \mathrm{C}$ (Blue), $45^{\circ} \mathrm{C}$ (Red), $50^{\circ} \mathrm{C}($ Green $)$, And $55^{\circ} \mathrm{C}$ (Purple)

2.5: Logistic Regression Models, $G_{t}=1-\left(1 /\left(1+e^{b 0-b 1 * h}\right)\right)$ of Nettleleaf Goosefoot at $40^{\circ} \mathrm{C}$ (Blue), $45^{\circ} \mathrm{C}($ Red $), 50^{\circ} \mathrm{C}($ Green $), 55^{\circ} \mathrm{C}$ (Purple) And $60^{\circ} \mathrm{C}$ (Orange).....

2.6: Logistic Regression Models, $\mathrm{G}_{\mathrm{t}}=1-\left(1 /\left(1+\mathrm{e}^{\mathrm{b} 0-\mathrm{b} 1 * \mathrm{~h}}\right)\right)$, of Redroot Pigweed at $45^{\circ} \mathrm{C}($ Red $), 50^{\circ} \mathrm{C}\left(\right.$ Green), $55^{\circ} \mathrm{C}$ (Purple) And $60^{\circ} \mathrm{C}$ (Orange)

2.7: Logistic Regression Models, $\mathrm{G}_{\mathrm{t}}=1-\left(1 /\left(1+\mathrm{e}^{\mathrm{b} 0-\mathrm{b} 1 * \mathrm{~h}}\right)\right)$ of Common Purslane at $50^{\circ} \mathrm{C}\left(\right.$ Green), $55^{\circ} \mathrm{C}$ (Purple) And $60^{\circ} \mathrm{C}$ (Orange).

2.8: Logistic Regression Models, $\mathrm{G}_{\mathrm{t}}=1-\left(1 /\left(1+\mathrm{e}^{\mathrm{b} 0-\mathrm{b} 1 * \mathrm{~h}}\right)\right)$, Of Little Mallow at $45^{\circ} \mathrm{C}$ (Red), $50^{\circ} \mathrm{C}\left(\right.$ Green), $55^{\circ} \mathrm{C}$ (Purple) And $60^{\circ} \mathrm{C}$ (Orange). 
3.1: Examples of Strawberries Ranked from 0-5 on The Disease Severity Scale.

3.2: Weed Biomass $\left(\mathrm{g} / \mathrm{m}^{2}\right)$ of Each Interaction Treatment Between Sudangrass and

Solarization Taken in December.

3.3: Verticillium dahliae Populations (Colony Forming Units (CFU)/g) in Solarized Vs Non-Solarized Treatments Taken from July 2018 (Pre-Solarization

Treatments) to June 2019 (End of Harvest).

3.4: Verticillium dahliae Populations (Colony Forming Units $(\mathrm{CFU}) / \mathrm{g}$ ) in

Sudangrass Treatments Taken from July 2018 (Pre-Solarization Treatments) to June 2019 (End of Harvest)

3.5: Average Canopy Volume $\left(\mathrm{cm}^{3}\right)$ Measurements Taken from Five Random

Plants per Plot Every Two Weeks During Strawberry Harvest (15 March To 30

June) in Solarized vs Non-Solarized Treatments

3.6: Average Canopy Nolume $\left(\mathrm{cm}^{3}\right)$ Measurements Taken from Five Random

Plants per Plot Every Two Weeks During Strawberry Harvest (15 March to 30

June) in Sudangrass Treatments

3.7: Disease Severity on a Scale of 0 (No Disease) to 5 (Dead) of Sudangrass

Treatments

3.8: Disease Severity on a Scale of 0 (No Disease) to 5 (Dead) in Solarized vs Non-

Solarized Treatments

A.1: Plot Layout of Field Experiment (Top). S=Solarized and NS=Non-Solarized. Location of Field Experiment on Cal Poly Organic Farm (Bottom) $\left(35^{\circ} 18^{\prime} 16.90^{\prime \prime} \mathrm{N} 120^{\circ} 40^{\prime} 19.83^{\prime \prime} \mathrm{W}\right)$. 


\section{Chapter 1}

\section{INTRODUCTION AND LITERATURE REVIEW}

\subsection{California Strawberry Production}

California strawberry (Fragaria $\times$ ananassa Duchesne) production was valued at over 3.1 billion dollars in 2018 and accounted for $88 \%$ of the United States' strawberry production (Fennimore et al. 2018). In California, organic strawberry acreage accounts for $13.1 \%$ of the total strawberry acreage (Anonymous 2019). Organic acreage is increasing due to increasing demand for organic strawberries, with most growers growing both organically and conventionally (Guthman 2017). Organic strawberry sales generated $\$ 55$ million in 2009 compared to 2 million in 1997 (Koike et al. 2012). However, organic growers still have limited options for weed and pathogen control.

\subsubsection{Weeds in Strawberry}

Due to the slow growth and shallow root system of strawberries, weeds can reduce strawberry yields if left uncontrolled. Weed management is most important during strawberry establishment (Carroll et al. 2016, Fennimore et al. 2018). In California strawberry production, conventional growers rely on soil fumigation, herbicides, handweeding, and plastic mulches for weed control (Fennimore et al. 2018). In addition to fumigants active ingedients flumioxazin, oxyfluorfen, and pendimethalin are commonly used herbicides in strawberry production (Department of Pesticide Regulation 2016).

Problem weeds in strawberries are weeds possessing hard seed coats such as little mallow (Malva parviflora L.), burclover (Medicago polymorpha L.), filaree (Erodium spp. L.), and sweet clover (Melilotus officinalis L.) as these weeds tend to survive fumigation (Anonymous 2003). These species can establish seedbanks that ensure 
persistent weed problems in the future. Other problematic weeds are wind-dispersed weeds such as annual sowthistle (Sonchus oleracea L.), horseweed (Conyza canadensis L.), and common groundsel (Senecio vulgaris L.) (Anonymous 2003). Additionally, fields with perennial weeds, such as nutsedge (Cyperus spp. L.), bindweed (Convolvulus arvensis L.), and bermudagrass (Cynodon dactylon L.), should be avoided by organic growers as these weeds are difficult to control with organic methods (Fennimore et al. 2018). Organic growers are unable to use chemicals and as such have higher hand-weeding costs. In 2019, average hand-weeding costs for organic growers were estimated to be 3,696 dollars per acre (Bolda et al. 2019). Meanwhile, in 2016 handweeding costs for conventional growers were estimated to be 1,642 dollars per acre (Bolda et al. 2016). Finding organic weed management techniques to reduce handweeding costs is vital to increasing the economic viability of organic strawberries.

\subsubsection{Diseases in Strawberry}

Verticillium dahliae Kleb. is an economically damaging fungus with a wide host range of over 400 plants including strawberry (Berlanger and Powelson 2005). Verticillium dahliae causes economic losses in temperate regions around the world and there are no current control measures once a plant is infected. There are six genetically distinct vegetative compatibility groups of $V$. dahliae (Klosterman et al. 2009). These different groups affect different plants. Some isolates of $V$. dahliae are fairly host specific, such as one isolate which only infects cotton. Other isolates can infect a broad range of host plants. For example, one isolate that infects strawberry can also infect artichoke, lettuce, potato, tomato, and watermelon (Bhat and Subarrao 1999, Puhalin and Hummel, 1983). 
Strawberries are particularly susceptible to Verticillium wilt caused by $V$. dahliae. UC extension specialists recommend not planting strawberries without fumigation if soils have $V$. dahliae levels of 10 colony forming units (CFU) per gram of soil or higher (Bolda and Koike 2013). However, studies have shown that disease incidence in strawberries can be as high as 50 percent with populations of just 1 to $2 \mathrm{~V}$. dahliae CFU/g of soil (Harris and Yang 1996).

\subsubsection{Fumigants}

The California strawberry industry relies heavily on soil fumigants which are used to control weeds, soilborne pathogens, and other soilborne pests. Low tolerances of weeds and pathogens make fumigation the most economically viable way to produce strawberries. Methyl bromide and chloropicrin combinations have been shown to reduce weed populations from 90 to $99 \%$ and $V$. dahliae populations by more than $99 \%$ (Hartz et al. 1993, Samtani et al. 2011, 2012). Combinations of chloropicrin and1,3-D also provide effective weed and pathogen control (Chamorro et al. 2015a, Shennan et al. 2018), however, they result in lower runner production when used in nurseries (García-Méndez et al. 2008, Larson and Shaw 2000). California strawberry yields averaged around 6,000 to $10,000 \mathrm{~kg} / \mathrm{ha}$ before the use of fumigation (Wilhelm et al. 1974). After 15 years of development of chloropicrin-methyl bromide mixtures, strawberry yields in fumigated fields ranged from 40,000-60,000 kg/ha (Wilhelm et al. 1974).

Environmental and human health risks of soil fumigants have led to restrictions on their use. Methyl bromide, the former soil fumigant of choice, is a known ozone depleting substance leading to its inclusion in the Montreal Protocol and subsequent phaseout. Methyl bromide was officially banned in 2005 (US EPA 2019). However, 
critical use exemptions were available for strawberry production until 2017. Besides its ozone depleting effect, methyl bromide also has serious human health effects, impairing respiratory function and leading to kidney and neurological damage (Budnik et al. 2012, US EPA 2000). Chloropicrin, now the most widely used fumigant, is designated as a toxic air contaminant by the EPA (US EPA 2008). Additionally, 1,3-D, another popular soil fumigant, is also a toxic air contaminant and listed as a possible (2b) carcinogen in the US (US EPA 1998).

Due to the health risks posed by fumigants, they are subject to strict regulations. Growers in urban areas cannot use high rates of 1,3-D as they are limited to $90,250 \mathrm{lb}$ per year per township, an area of 36 square miles. Other restrictions in place are buffer zones, re-entry periods for workers, respiratory protection, TIF (totally impermeable film) tarps, and restricted application rates. These restrictions increase the cost of fumigation which averages $\$ 8160$ per hectare (Tourte et al. 2016). Costs of regulation are increased on smaller farms and farms near urban areas, potentially leading to the loss of strawberry acreage in these areas (Carter et al. 2009, Guthman 2017)

Increased costs of fumigation due to increasing regulations are problematic for California's strawberry industry. Growers are still reliant on fumigation in order to effectively control pests as non-fumigant alternatives have not been developed to meet grower's needs. Increased research and outreach on alternatives to soil fumigation are needed in order to keep the strawberry industry viable in California (Gorder et al. 2013). 


\subsection{Alternatives to Soil Fumigation for Soil Disinfestation}

Increasing costs and regulations of soil fumigation have driven research into alternative soil disinfestation techniques in a variety of cropping systems. The following section will review relevant non-chemical, alternative soil disinfestation techniques and how they relate to strawberry production.

\subsubsection{Soil Steaming}

Soil steaming uses steam to heat soil to lethal temperatures for pathogens and weeds. Steam effectively eliminates soilborne pathogens, weeds, and other soilborne pests although success depends on the duration of the steaming treatment and resultant soil temperatures. Factors affecting steaming efficacy are soil structure and moisture. Van Loenen et al. (2003) found that wet soils were more effective than dry soils when using steaming. Dry soils required soil temperatures $20^{\circ} \mathrm{C}$ higher to kill the pathogen Sclerotinia sclerotiorum Lib. (De Bary) than wet soils (Van Loenen et al. 2003). Melander and Kristensen (2011) found that soil steaming in fine, wet, clay soil led to better control of weeds than in sandy soils with coarser structure. They suspected heat penetration was more effective in wet soils and soils with finer particles leading to better heat conduction, easier dispersion of heat through the soil, and lower soil temperatures required to kill pests (Melander and Kristensen, 2011). These same principles can be applied to other soil heating techniques such as soil solarization. 
Table 1.1: Lethal Soil Temperatures and Durations for Management Of Soilborne Pests in Soil Steaming Applications Under Moist Conditions. (Adapted from UNEP 2001).

\begin{tabular}{cc}
\hline Soil-borne pests & Lethal soil temperature and duration \\
\hline Nematodes & $49^{\circ} \mathrm{C}$ for $30 \mathrm{~min}$ \\
$\begin{array}{c}\text { Most plant pathogenic fungi and } \\
\text { most plant pathogenic bacteria } \\
\text { Soil insects }\end{array}$ & $62^{\circ} \mathrm{C}$ for $30 \mathrm{~min}$ \\
Virtually all plant pathogenic \\
bacteria and most plant viruses \\
Most weed seeds & $60-71^{\circ} \mathrm{C}$ for $30 \mathrm{~min}$ \\
Tomato mosaic virus in root debris & $71{ }^{\circ} \mathrm{C}$ for $30 \mathrm{~min}$ \\
$\begin{array}{l}\text { A few species of resistant weed } \\
\text { seeds and resistant plant viruses }\end{array}$ & $71-82^{\circ} \mathrm{C}$ for $30 \mathrm{~min}$ \\
\hline
\end{tabular}

\subsubsection{Steaming in Strawberry Production}

Steam treatments have provided comparable weed control and strawberry yields to fumigation treatments in California strawberry production (Fennimore et al. 2013, Samtani et al. 2011, 2012). Steam trials in Salinas provided similar V. dahliae control to methyl bromide down to $15 \mathrm{~cm}$. However, at 30 and $45 \mathrm{~cm}$ methyl bromide provided better control of $V$. dahliae than steaming (Samtani et al. 2012). Additionally, steam treatments in Oxnard were unable to eliminate Fusarium oxysporum Schlecht. (emend. Snyder \& Hansen) or Macrophomina phaseolina Tassi. (Gold) from soils in strawberry production (Daugovish et al. 2016).

\subsubsection{Limitations}

Steam application is expensive, as steamers expend a large amount of fuel and require more labor and time compared to soil fumigation (Fennimore and Goodhue 2016). Soil steaming in Ventura County was estimated to cost $\$ 12,350$ per hectare in order to provide acceptable control (Fennimore et al. 2014). This is much higher than fumigation or other alternative soil disinfestation techniques resulting in slimmer profit 
margins (Fennimore et al. 2013, Samtani et al. 2012). These reduced profit margins compared to other soil disinfestation techniques have slowed steaming's adoption despite its efficacy.

\subsubsection{Soil Solarization}

Soil solarization is an organic method that has displayed effective weed, pathogen, and nematode control comparable to that of chemical alternatives. Solarization involves placing clear, thin $(25-50 \mu \mathrm{m})$, low-density polyethylene tarps over irrigated soil to increase soil temperatures to lethal levels for pathogens, pests, and weeds. The tarp is left on the soil for 4 to 8 weeks, depending on the soil temperatures generated during solarization. Shortwave solar radiation $\left(\mathrm{W} / \mathrm{m}^{2}\right)$, soil heat transfer properties, longwave radiation exchange between tarp, soil and the air, and ambient air temperature are the primary factors in determining the efficacy of solarization (Marshall et al. 2013). Solarization is most effective when used during the summer when solar radiation is high in sunny, warm climates.

\subsubsection{Weed Management}

Solarization can control many weeds in California cropping systems (Elmore et al. 1997). Field research on parsley in the San Joaquin valley showed a reduction in weed numbers between $86 \%$ and $94 \%$, and a reduction in weed biomass between $94 \%$ and $99 \%$ when compared to non-solarized plots (Stapleton et al. 2008a). Similarly, in Italy a solarization experiment on lettuce reduced populations of annual and perennial weeds by over 85\%, except for purple nutsedge (Cyeprus rotundus L.) and Mediterranean sweet clover (Melilotus sulcatus L.), compared to an untreated control (Candido et al. 2011). 
Some weeds are more susceptible to solarization than others. For example, shorter times are required to kill cool-season annuals than warm-season annuals (Dahlquist et al. 2007). Additionally, perennial weeds such as field bindweed and nutsedge are more difficult control with solarization than annual weeds (Elmore et al. 1993, Stapleton et al. 2008b). For example, purple (Cyperus rotundus L.) and yellow nutsedge (Cyperus esculentus) tuber mortality will not occur until exposed to temperatures of $50^{\circ} \mathrm{C}$ or higher (Webster 2003). Additionally, many hard-seeded weeds including little mallow and legume species such as sweet clover are difficult to control with solarization requiring longer solarization periods to achieve results (El-Keblawy and Al-Hamadi 2009). Perennial and hard-seeded weeds require daily maximum temperatures of $50^{\circ} \mathrm{C}$ or higher for at least a 4 to 6 weeks to achieve adequate control (Elmore, 1997).

\subsubsection{Pathogen Management}

Soil solarization has shown the capability to reduce the soilborne populations of many bacterial and fungal pathogens. A study on the management of Fusarium wilt found that solarization significantly reduced disease incidence in lettuce between $42 \%$ and $91 \%$ in 7 trials over 4 years (Matheron and Porchas 2010). Patricio et al. (2006) found solarization significantly reduced bottom rot (caused by Rhizoctonia solani Kuhn.) and lettuce drop (caused by Sclerotinia minor Jagger.) in a lettuce crop compared to two fungicides, pencycuron and procymidone (Patrício et al. 2006). Additionally, soil solarization was found to significantly reduce the disease incidence of Verticillium wilt in eggplant, olive trees, and artichoke (Berbegal et al., 2008; Lopez-Escudero \& BlancoLopez, 2001; Tamietti \& Valentino, 2001) 


\subsubsection{Effect on Yields}

Solarization has increased yields in a variety of crops (Figure 1.1). Potential reasons for increased yields are reductions in pathogen and weed populations, larger availability of heat solubilized nutrients, and changes in plant physiology (Candido et al., 2011). Yield increases are often enough to justify the solarization costs, which are relatively cheap compared to fumigants, at $\$ 865$ to $\$ 1975$ a hectare (Stapleton et al., 2008).

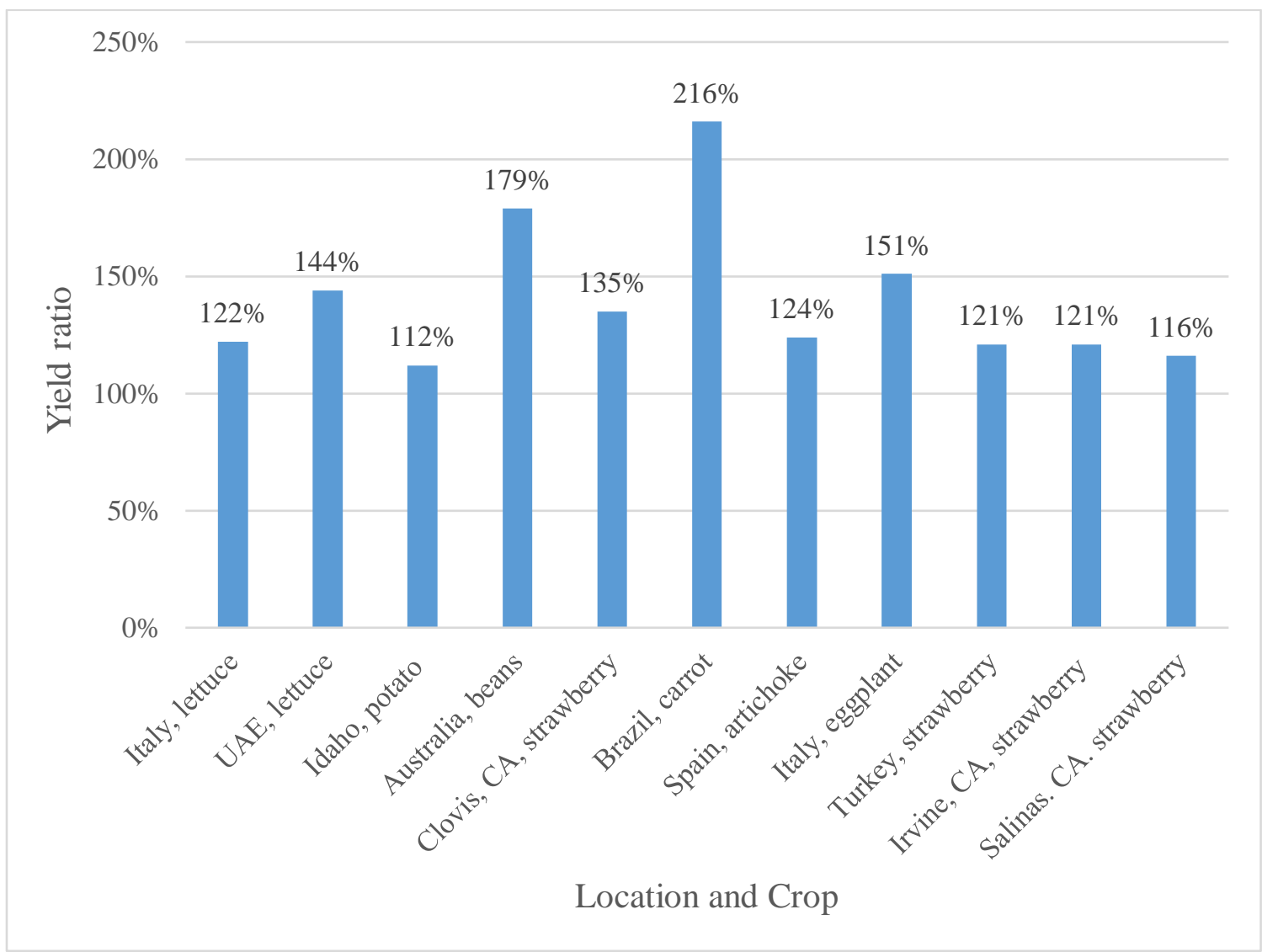

Figure 1.1: Ratio (\%) of Yields on Solarized Fields Compared to Untreated/Control Fields in a Variety of Vegetable Crops and Berry Crops (Lettuce, Potato, Strawberry, Carrot, Eggplant, Artichoke, and Beans) And Their Respective Locations. Data compiled from (Al-masoom et al. 1993, Berbegal et al. 2008, Candido et al. 2011, Hartz et al. 1993, MacGuidwin et al. 2012, Marenco and Lustosa 2000, Porter and Merriman 1983, Samtani et al. 2012, Stapleton et al. 2008a, Tamietti and Valentino 2001, Yildiz et al. 2010). 


\subsubsection{Solarization in Strawberries}

Solarization has had success when used in strawberry production systems around the world, achieving results similar methyl bromide and other fumigants. In Turkey, soil solarization provided weed reduction, except for purple nutsedge, and reduced mortality from M. phaseolina leading to increased yields over untreated control (Yildiz et al. 2010). Applications of solarization in Italy and Georgia resulted in similar yields compared to methyl bromide (Iapichino et al. 2008, Rieger et al. 2001).

Multiple studies in California have tested the efficacy of solarization on strawberries. In Irvine, solarization reduced weed, $V$. dahliae populations, and Phytophthora cactorum J. Schröt. (Lebert and Cohn) populations, over untreated controls and improved yields comparable to those of methyl bromide (Hartz et al. 1993). Application of solarization with mustard seed meal in Ventura county were unable to reduce $M$. phaseolina and $F$. oxysporum levels compared to the untreated control. However, yield was increased over the control in 1 out of 2 years (Daugovish et al. 2016). In Salinas, solarization was less effective, providing no reduction in $V$. dahliae populations compared to untreated controls. Additionally, only partial control was provided for most weed species over untreated plots. Solarization provided no control of common purslane and yellow nutsedge (Samtani et al. 2012).

These results indicate solarization may only be effective in southern California strawberry production regions with warmer temperatures and higher solar radiation. Additionally, California strawberry pathogens $M$. phaseolina and $F$. oxysporum are more heat-tolerant and less susceptible to solarization (Yildiz et al. 2010). More research is 
needed on integrating solarization into strawberry production systems as well as combining it with other techniques such as biofumigation or anaerobic soil disinfestation to increase efficacy.

\subsubsection{Biofumigants and Other Organic Amendments}

Biofumigation is the use of decomposing plant and animal residues which release volatile compounds with pesticidal properties for soil disinfestation (Youssef 2015). Plants from the Brassicaceae family are the most researched biofumigant due to their release of secondary plant compounds called glucosinates (Earlywine et al., 2012). These secondary glucosinates breakdown into isothiocyanates which have toxic properties able to reduce the viability of pathogens and weed seeds in the soil.

Application of brassica seed meals have provided inconsistent results against plant pathogens and weeds. In several trials, brassica seed meal applications did not consistently reduce $V$. dahliae or $M$. phaseolina populations to the required densities required to grow strawberries (Mazzola et al. 2017, Motisi et al. 2010, Muramoto et al. 2016). Some trials have provided substantial reductions in weed biomass over untreated controls (Mazzola et al. 2017). However, other trials have shown no effect on reducing weed populations over untreated plots (Fennimore et al. 2013, Samtani et al. 2011, Shennan et al. 2018). Tarped applications of mustard seed meal have shown better control of weeds and pathogens than non-tarped applications (Earlywine et al. 2010). This explains some of the inconsistencies in efficacy in controlling weeds, but even in tarped application results are still variable (Mazzola et al. 2017, Meyer et al. 2011). Application with mustard seed meal tends to result in lower strawberry yields than 
fumigated controls or other alternative soil disinfestation techniques such as anaerobic soil disinfestation (Fennimore et al. 2013, Muramoto et al. 2016).

Residues from other plant materials outside of the Brassicaceae family have been tested for effectiveness versus soilborne pathogens. For example, terpenes isolated from lavender oil waste products were shown to be more effective in reducing $V$. dahliae populations when compared to BioFence, a product made from mustard seed meal (Wei et al, 2016). Wheat residues suppressed Macrophomina crown rot incidence in strawberries more consistently than mustard seed meals (Mazzola et al. 2017). Additionally, other green manures including sudangrass, buckwheat, canola, and Australian winter pea can reduce the inoculum density of $V$. dahliae at varying levels (Ochiai et al., 2008; Wiggins and Kinkel, 2004). More research is needed into nonBrassicaceae plant residues to determine their effectiveness as biofumigants.

\subsubsection{Anaerobic Soil Disinfestation}

Anaerobic soil disinfestation is a promising alternative to fumigation which has been shown to reduce pathogens and increase yields in a variety of vegetable and berry cropping systems (Shennan et al. 2018). Anaerobic soil disinfestation involves incorporating a degradable organic matter source high in carbon, such as molasses or rice bran, then placing an impermeable plastic mulch over flooded soil to create anaerobic conditions (Mazzola et al., 2018). Mechanisms for pathogen reduction and yield increase are not yet fully understood, but exposure to anaerobic conditions. and increased microbial diversity all contribute to pathogen suppression and increased yields (Mazzola et al. 2018, Muramoto et al. 2016). Anaerobic soil disinfestation is very similar to biosolarization (see Section 1.2.5) except lethal heating is not achieved via anaerobic soil 
disinfestation and biosolarization attempts to maintain slightly aerobic conditions (Stapleton et al. 2016)

Multiple studies have documented anaerobic soil disinfestation's efficacy on $V$. dahliae and other strawberry pathogens. Anaerobic soil disinfestation was found to have higher levels of control than chemical treatments in a study on $V$. dahliae in potato fields (Korthals et al. 2014). In multiple field trials conducted along the central coast of California, anaerobic soil disinfestation using a combination of rice bran and rice bran combined with mustard seed meal, significantly reduced the inoculum density of $V$. dahliae in soils by 81 to $100 \%$ compared to an untreated control (Shennan et al, 2018). In a trial comparing anaerobic soil disinfestation using rice bran and a mustard seed meal application, anaerobic soil disinfestation using rice bran resulted in better disease suppression of Macrophomina crown rot leading to increased yields (Muramoto et al. 2016). However, anaerobic soil disinfestation trials in California have been ineffective in controlling populations of $F$. oxysporum f. sp. fragariae (Muramoto et al. 2016, Shennan et al. 2018).

One disadvantage of anaerobic soil disinfestation is its variable weed control, (Zavatta et al. 2014). In multiple California field trials anaerobic soil disinfestation has shown significant but modest, only $29 \%$, reduction, over untreated plots and other times has had no significant effect on weed populations (Fennimore et al. 2013, Shennan et al. 2018, Zavatta et al. 2014). Applications of anaerobic soil disinfestation with molasses have provided good control of nutsedge and excellent control of grass and broadleaf weeds in sub-tropical Florida where soil temperatures are warmer during anaerobic soil disinfestation (Rosskopf et al. 2010). Performing anaerobic soil disinfestation under 
warm conditions, combines the effects of anaerobic soil disinfestation with soil solarization, and can lead to better results as pathogens show higher susceptibility to anaerobic soil disinfestation under warmer temperatures. For example, at $40{ }^{\circ} \mathrm{C}$ it took 3 days to kill $V$.dahliae under anaerobic conditions, whereas at $20{ }^{\circ} \mathrm{C}$ it took 212 days to eradicate V. dahliae (Ebihara and Uematsu, 2014). In Florida, a 3-week study of molasses applied under solarization tarps using anaerobic conditions, provided more effective control of $F$. oxysporum and Meloidogyne incognita Chitwood. then solarization alone (Butler et al. 2012). Performing anaerobic soil disinfestation during summer months could result in higher temperatures yielding better pathogen and weed control then anaerobic soil disinfestation conducted in winter months.

\subsubsection{Biosolarization}

Biosolarization, which combines the use of organic soil amendments and soil solarization, has been proven to enhance the results of solarization in numerous field experiments. Organic amendments commonly used are plant residues, animal manure, compost and other high nitrogen organic materials such as blood meal (Gamliel and Katan 2012). Multiple studies have shown increased efficacy of solarization by combining solarization with application of organic amendments. The increased efficacy of solarization is a result of multiple mechanisms.

1) Tarping the soil prevents biocidal gases released during decomposition of organic materials from escaping and increases their penetration throughout the soil via heat exposure (Gamliel et al. 2000). These gases can result in direct toxicity against both beneficial and pathogenic soilborne organisms (Cantor et al. 2011). 
2) Incorporating organic amendments into soils increases microbial activity. These microbes can compete with and suppress detrimental soilborne organisms (Simmons et al. 2016).

3) Increased microbial activity during biosolarization can increase soil temperatures from 2 to $5^{\circ} \mathrm{C}$ during soil solarization. (Gamliel and Stapleton 1993a, Simmons et al. 2013). However, this effect is not consistent across all biosolarization treatments (Peachey et al. 2001).

4) Additionally, tarping soil amended with high carbon inputs (i.e., rice bran, molasses) can lead to an increase in accumulation of organic acids released from anaerobic bacteria which are toxic to many soilborne pathogens (Simmons et al. 2016).

5) Lastly, disinfestation resulting from anaerobic conditions and high temperatures from soil solarization still result during biosolarization.

Multiple studies have documented success controlling pathogens at sublethal solarization temperatures when organic amendments were used in combination with solarization (Blok et al. 2000, Núñez-zofío et al. 2011, Tjamos and Fravel 1995). For example, the biosolarization of cabbage residues on 2 kinds of Phytophthora root rot were shown to reduce the population of both species at soil depths where an adequate soil temperature to kill the pathogen was not achieved (Coelho et al. 2001). Similarly, the solarization of broccoli and other cruciferous residues have controlled $M$. incognita even at temperatures below lethal levels. (Stapleton and Duncan, 1998). Biosolarization could potentially expand the use of solarization to temperate regions where normally solarization would not generate lethal temperatures for soilborne pests. 


\subsubsection{Biosolarization in Strawberry}

Multiple studies on biosolarization in Spain have documented the capability of different biosolarization treatments against the strawberry pathogens $M$. phaseolina and F. oxysporum f. sp. fragariae. All biosolarization treatments increased yields and reduced disease incidence and inoculum density of M. phaseolina and F. oxysporum $f$. sp. fragariae pathogens and root knot nematode Meloidogyne hapla Chitwood. over untreated controls (Domínguez et al. 2016). Biosolarization treatments which provided the highest yield and most significant reduction of pathogens were dried olive pomace + 50 UF nitrogen under virtually impermeable film (VIF )film (12,500 kg/ha) and fresh chicken manure $(12,500 \mathrm{~kg} / \mathrm{ha})$ under standard solarization plastic (Domínguez et al. $2014,2016)$. Biosolarization of fresh chicken manure $(25,000 \mathrm{~kg} / \mathrm{acre})$ under solarization plastic reduced $M$. phaseolina populations to levels similar to those of fumigants. Despite similar pathogen load, higher plant mortality from $M$. phaseolina and lower yields occurred in chicken manure/biosolarized treatments in one out of two fields compared to fumigated treatments (Chamorro et al. 2015a). Biosolarization costs ranged from $\$ 335$ to $\$ 2,225$ less per hectare than conventional treatments depending on the organic amendment applied (Chamorro et al. 2015a). Results demonstrated that biosolarization is effective in reducing plant pathogen populations, and although not as consistent effective as fumigants they are potentially more economically viable due to cheaper application costs. 


\subsubsection{Biofumigation Potential of Sorghum spp.}

Outside of the Brassicaceae family, another family of plants with potential for use as biofumigants is the Poaceae family. Microreactor experiments showed that incorporating grass residues into soil can reduce soilborne pathogen populations of root knot nematodes, Sclerotium rolfsii Sacc. and Pythium ultimum Trow. (Stapleton et al. 2010). In fields trials, Sorghum spp. Moench. such as sorghum, sudangrass, and sudex, a sorghum-sudangrass hybrid, have been shown to reduce populations of root knot nematodes when incorporated into the soil as a green manure (Widmer and Abawi 2000, 2002). Additionally, incorporation of sudangrass residues has shown the ability to reduce populations of $V$. dahliae and reduce Verticillium wilt disease incidence in potatoes improving yields over controls (Davis et al. 2004, MacGuidwin et al. 2012). However, reduction of $V$. dahliae populations over untreated soil is variable, and did not occur in all experiments although reduction in Verticillium wilt of potatoes was consistent (Davis et al. 2004). Likewise, the biofumigation of sudangrass is not effective against all pathogens and nematodes. Sudangrass has been found to have no effect on reducing populations of Pratylenchus penetrans Cobb. and Phytophthora cinnamomi Rands. when incorporated as a green manure (MacGuidwin et al. 2012, Pinkerton et al. 2002).

The mechanism for biofumigation in Sorghum spp. is a chemical reaction that converts dhurrin, a chemical present in varying amounts in different Sorghum spp., into a hydrogen cyanide gas. The vacuoles of epidermal cells contain dhurrin and the mesophyll cells contain a catalytic enzyme $\beta$-d-glucoside glucohydrolase or dhurrinase (De Nicola et al. 2011). When plant tissue is damaged or starts to decompose, these 
chemicals come into contact. The enzyme catalyzes a chemical reaction hydrolyzing dhurrin into $p$-hydroxymandelonitrile. The chemical then dissociates into hydrogen cyanide and p-hydroxybenzadehyde (Widmer and Abawi 2000). For nematodes, a concentration of $0.1 \mathrm{ppm}$ of hydrogen cyanide is needed to kill a $M$. hapla egg, while a 1 ppm concentration is needed to kill M. hapla stage 2 juveniles (Widmer and Abawi 2000). Different cultivars of Sorghum spp. contain different amounts of dhurrin making some varieties more toxic than others. For example, the sorghum cultivar 'Super dolce' contained the highest dhurrin content in its aboveground parts while the 'Piper' cultivar of sudangrass contained the highest dhurrin content in its roots. As sudangrass grew and reached maturity, dhurrin concentrations decreased in its aboveground parts and increased in its belowground parts (De Nicola et al. 2011).

Sorghum spp. also contain the allelochemical chemical sorgoleone which has been shown to suppress weed germination and growth. Sorghum spp. produce sorgoleone from root hair cells as long as the plant maintains active root growth (Weston et al. 2013). Sorgoleone is phytotoxic to a broad range of plant species and acts on young seedlings and seedling shoots less than a week old by inhibiting photosynthesis through disrupting the electron transport chain (Dayan et al. 2009).

Experiments incorporating Sorghum spp. green manure have shown variable control of weeds. For example, a study in Georgia found no reduction in weed biomass over a control two months after sorghum incorporation (Nyczepir and Rodriguez-Kabana 2007). A field experiment done on the weed control of a mulched and incorporated sudex cover crop in Fresno, California found incorporated residues reduced weed biomass over control plots. However, mulched residues were more effective than incorporated residues 
in reducing weed populations (Stapleton et al. 2010). The efficacy of incorporated residues likely differs from variety to variety based on the amount of dhurrin and sorgoleone produced by different cultivars. Mulched residues may result in better weed reduction due to the thick ground cover of Sorghum spp. mulches in addition to its allelopathic properties.

\subsubsection{Biosolarization of Sudangrass}

Researchers in Oregon conducted a study on the effects of solarized and nonsolarized treatments of rapeseed, sudangrass, and barley cover crops on annual bluegrass (Poa аппиа L.) control (Peachey et al. 2001). Researchers found that solarization + sudangrass reduced bluegrass seed viability in the top $5 \mathrm{~cm}$ of the soil by 89 to 100 percent. However, seed viability increased between 5 and $10 \mathrm{~cm}$ compared to the control (Peachey et al. 2001) Reduced suppression of annual bluegrass compared to other weed species has been noted in other studies involving Sorghum spp. as well (Stapleton et al. 2010). When combined with solarization in Oregon, sudangrass effectively reduced populations of $V$. dahliae, nematode P.penetrans, P. cinnamomi, and tree gall infection from Agrobacterium spp. Conn. (Pinkerton et al. 2000). However, sudangrass did not enhance the effects of solarization (Pinkerton et al. 2000). Sudangrass residues combined with solarization in Idaho potato production reduced $V$. dahliae populations and increased yields beyond those of a non-fumigated control (MacGuidwin et al. 2012). 


\title{
Chapter 2
}

\section{LOGISTIC REGRESSION MODELS OF IMPORTANT WEED SPECIES RESPONSE TO SOIL SOLARIZATION}

\begin{abstract}
2.1 Introduction
Soil solarization is an organic soil disinfestation technique which creates lethal temperatures for soil-borne organisms through the placement of a clear, thin $(25-50 \mu \mathrm{m})$ plastic tarp over the surface of wet soil for 4 to 8 weeks (Gamliel and Katan 2012). It has been effectively used for weed and pathogen management in areas with warm, sunny summers including California's central valley (Elmore et al. 1997, Stapleton et al. 2008b, 2008a). However, weed seeds differ in susceptibility to temperatures generated during solarization (Dahlquist et al. 2007).

Models simulating thermal tolerance of weed species to soil steaming have been documented for multiple species (Hoyle and Mcelroy 2012, Melander and Jørgensen 2005, Melander and Kristensen 2011). Steaming experiments demonstrate that exposure to $70^{\circ} \mathrm{C}$ for 30 minutes under moist conditions kills most weed seeds (Van Loenen et al. 2003). Solarization, however, rarely achieves temperatures this high and generally generates temperatures between 40 and $60^{\circ} \mathrm{C}$ (Stapleton et al. 2008b). Soil temperatures only reach these temperatures for a few hours each day and thermal death occurs slowly over time (Horowitz and Taylorson 1983). Thus, simulating solarization and steaming require different models due to the differences in temperature.

Different weeds vary in their susceptibility to solarization. Shorter times are required to kill cool-season annuals than warm-season annuals (Dahlquist et al. 2007). Additionally, perennial weeds such as field bindweed (Convolvulus arvensis L.) and
\end{abstract}


nutsedge (Cyperus spp. L.) are more difficult to control with solarization than annual weeds (Elmore et al. 1993, Stapleton et al. 2008b). For example, nutsedge tuber mortality will not occur until exposed to temperatures of $50^{\circ} \mathrm{C}$ or higher (Webster 2003). Also, many hard-seeded weeds with thick seed coats are difficult to control with solarization requiring longer solarization periods to achieve mortality (Egley 1990, El-Keblawy and Al-Hamadi 2009, Rubin and Benjamin 1984).

Logistic and Weibull models simulating the response of important weed species to solarization temperatures have been created for a few important weed species. Logistic models and thermal death thresholds have also been created for five important pathogen species (Pullman et al. 1981a, Yildiz et al. 2010). To refine applications of solarization, models need to be developed for more species of weeds and pathogens. A greater understanding of temperature-duration mortality thresholds for weeds and pathogens could help practitioners understand and optimize the effects of solarization against weeds and pathogens.

A wide variety of weed species were chosen due to their importance to California agriculture and prominence on the Cal Poly Organic Farm. Species selected are annual sowthistle (Sonchus oleracea L.), bristly oxtongue (Picris echioides L.), nettleleaf goosefoot (Chenopodium murale L.), redroot pigweed (Amaranthus retroflexus L.), common purslane (Portulaca oleracea L.), little mallow (Malva parviflora L.), and redstem filaree (Erodium cicutarium L.) (Table 2.1). Species were selected to include hard-seeded weeds, warm-season annuals, and cool-season annuals. Hard-seeded weed species little mallow and redstem filaree are of particular importance to California agriculture as they are resistant to soil fumigation and many herbicides which are 
commonly used in strawberries, a major commodity in California (Fennimore 2012, Samtani et al. 2012, Wu and Dastgheib 2001)

Table 2.1: List of Weed Species Tested Divided Into Three Categories: Hard-seeded weeds, warm-season weeds, and cool-season weeds.

\begin{tabular}{|c|c|}
\hline Weed type & Species \\
\hline Hard-seeded & Little mallow \\
& Redstem filaree \\
\hline Warm-season & Common purslane \\
& Nettleleaf goosefoot \\
& Redroot pigweed \\
\hline Cool-season & Annual sowthistle \\
& Bristly oxtongue \\
\hline
\end{tabular}

The objectives of this experiment were to:

1) determine germination rates of important California weed species after exposure to solarization temperatures of 40 to $60^{\circ} \mathrm{C}$ for a variety of time intervals, and

2) use the germination rates to create regression models simulating response of weed speeds to solarization temperatures.

\subsection{Materials and Methods}

\subsubsection{Seed Collection and Preparation}

All seeds were collected in spring/summer 2018 from the Cal Poly Organic Farm in San Luis Obispo, California (35'18'16.90” N 12040’19.83” W). The cropping systems in this farm are mixed vegetables. After collection, seeds were stored in paper bags at room temperature $\left(21^{\circ} \mathrm{C}\right)$ except nettleleaf goosefoot seeds which were stored at $4^{\circ} \mathrm{C}$ as cold storage increases Chenopodium spp. germination rates (Moravcova and Dostalek 1989). Seeds were separated from chaff and 15 seeds were placed in $4 \mathrm{~cm}$ square seed packets made from organdy fabric (Dahlquist et al. 2007). Before conducting experiments, seed packets were rinsed for 5 seconds in deionized water then placed in a damp paper towel inside an open plastic bag overnight to imbibe moisture. 


\subsubsection{Thermal Treatments}

Each temperature and time consisted of six treatment replications and three control replications. Each replication consisted of one seed packet. Seeds were tested at 5 different temperatures $\left(60^{\circ} \mathrm{C}, 55^{\circ} \mathrm{C}, 50^{\circ} \mathrm{C}, 45^{\circ} \mathrm{C}\right.$, and $\left.40^{\circ} \mathrm{C} \pm 1.5^{\circ} \mathrm{C}\right)$ representing the range of temperatures frequently achieved by solarization. To conduct experiments, $400 \mathrm{~mL}$ mason jars were filled with $100 \mathrm{~mL}$ of sand (Quikrete all-purpose sand, Quikrete Cement and Concrete Products, Atlanta, GA, USA), then three seed packets were placed in the jar. Mason jars were filled to the top with sand and deionized water was added to field capacity. To fully simulate solarization conditions and minimize moisture loss, mason jars were covered with 2 mil clear low-density polyethylene (LDPE) plastic held in place by screwing on the mason jar cap (Dahlquist et al. 2007).

Experiments running 8 hours or less were placed in a water bath (Shaker Bath 3520, Labline Instruments, Melrose Park, IL, USA). Longer treatments of 10 hours or greater were placed in a thermal convection oven (Isotemp Oven 750F, Fisher Scientific, Pittsburgh, PA, USA), as water baths were unable to hold constant temperatures overnight. Temperature of sand in mason jar microcosms took 30 minutes to equilibrate with water bath temperature. After sand reached equilibrium with water bath the timer was started.

Sand in microcosms placed in thermal convection oven treatments took longer to equilibrate to oven temperature. To account for longer equilibration times mason jars were placed into ovens before seed packets were inserted and allowed to equilibrate to oven temperature. Once sand in mason jars had equilibrated with oven temperatures, seed packets were inserted to a depth of $5 \mathrm{~cm}$. Insertion of seed packets caused a slight loss of 
temperature in mason jar microcosms. Microcosms took roughly 30 minutes to reequilibrate themselves with oven temperatures after insertion of seeds. Timer was started after this 30-minute time interval.

Temperatures were recorded using temperature data loggers in the oven (Thermo Recorder Tr72wf, T\&D Corporation, Matsumoto, Japan and Ibutton Thermocron F5, Maxim Integrated, San Jose, CA, USA) and water bath (ECHO EM50 Datalogger and STE 50 Data Probe, Decagon Instruments, Pullman, WA, USA). Temperatures inside mason jars were monitored using thermometers (ERTCO Scientific Thermometer, Thermo Fisher Scientific, Waltham, MA, USA).

\subsubsection{Seed Germination Tests}

After treatments were completed, seed packets were immediately removed from mason jars, dipped in deionized water, and place on paper towels to dry. Once dry, some species were scarified nondestructively between two pieces of sandpaper to overcome physical dormancy, allowing seeds to imbibe water. To overcome physical seed dormancy, little mallow seeds were scarified for 60 seconds between 2 pieces of 60 grit sandpaper. Redstem filaree was scarified for 45 seconds with 60 grit sandpaper.

Nettleleaf goosefoot and redroot pigweed were both scarified for 10 seconds between two pieces of 100 grit sandpaper. Scarification times were determined after preliminary tests investigating scarification time and sandpaper roughness. Annual sowthisle, bristly oxtongue, and common purslane were not scarified as they germinated readily without scarification. Scarification duration was based on the thickness of the seed coat.

After scarification, seeds were placed in $100 \mathrm{~mm}$ x $15 \mathrm{~mm}$ petri dishes lined with 2 coffee filter papers. Petri dishes were filled with $1 \mathrm{~mL}$ of deionized water and placed in 
a growth chamber (Series 109 , Percival Scientific, Perry, IA, USA) set to a $25^{\circ} \mathrm{C} / 16$ hour day and $15^{\circ} \mathrm{C} / 8$ hour night cycle. Filter paper was kept moist with deionized water and seeds were checked daily. Germination was counted after two weeks. Seeds were counted as germinated if the radicle had emerged at least $3 \mathrm{~mm}$.

Redstem filaree and little mallow underwent additional scarification after a twoweek germination period as scarifying once was not enough to overcome dormancy in all seeds. After two weeks, all germinated mallow and filaree seeds were removed from petri dishes. Non-germinated seeds were dried then re-scarified for 20 seconds between two pieces of 60 grit sandpaper. After scarification, seeds were returned to the growth chamber under the same conditions and counted again after one week.

\subsubsection{Verification of Germination Tests}

In June 2019, non-germinated seeds underwent a one week germination test under the same methods previously described to protect against secondary dormancy which can occur during solarization (Mauromicale et al. 2005).

To verify accuracy of germination results and models, non-germinated seeds underwent tetrazolium testing. Ten random seeds were selected from each temperature and time combination. Seeds were placed on damp paper towels for at least $24 \mathrm{~h}$ to imbibe moisture. Then, seeds were placed in a $1 \%$ tetrazolium solution (wt/vol) for $24 \mathrm{~h}$ at $25^{\circ} \mathrm{C}$ under dark conditions. After $24 \mathrm{~h}$, seeds were removed from the solution and dried. Embryos were carefully removed from seed coat and inspected for staining under a dissecting microscope. Seed embryos that were stained red were considered viable. Seeds with no red staining or irregular staining were considered non-viable (Figure 2.1). 
Common purslane seeds were not tested as they were too small to puncture with a needle and the seed coat did not absorb tetrazolium, making evaluation impossible.
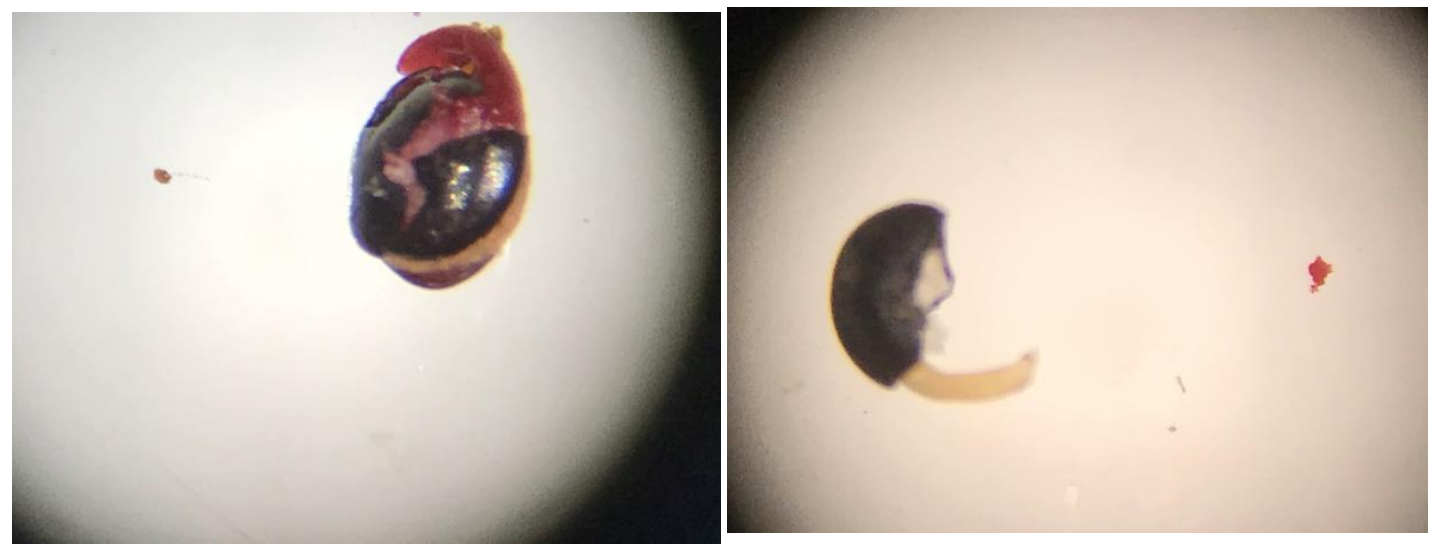

Figure 2.1: Examples of Two Nettleleaf Goosefoot Seeds, One Viable (Left) and One Non-Viable (Right) Soaked in 1\% (Wt/Vol) Tetrazolium Solution for 24 Hours.

\subsubsection{Statistical Analysis}

Models were created at all temperatures where seed germination was reduced. Ttests were used to compare control germination rates and treatment germination rates to determine if treatments had a significant effect. When a significant effect was observed, a model was created for the species. Models were not created for species at temperatures which did not significantly decrease germination rates or where treatments germinated at higher rates than controls (Table 2.2). 
Table 2.2: Species and Temperatures Where a Significant Decrease in Germination Rate was Not

Observed. Treatment and control germination rate are shown for experiments at the longest time tested for each specific species and temperature. $P$-values generated using a t-test ( $p \leq .05)$.

$*=$ Seeds germinated inside microcosms at this temperature.

\begin{tabular}{cccccc}
\hline & $\begin{array}{c}\text { Temperature } \\
\left({ }^{\circ} \mathrm{C}\right)\end{array}$ & $\begin{array}{c}\text { Treatment } \\
\text { germination } \\
\text { rate }(\%)\end{array}$ & $\begin{array}{c}\text { Control } \\
\text { germination } \\
\text { rate }(\%)\end{array}$ & $\begin{array}{c}\text { Exposure } \\
\text { Time } \\
\text { (hours) }\end{array}$ & $\operatorname{Pr}>F$ \\
\hline Redstem filaree & 60 & 34.3 & 26.2 & 240 & 0.405 \\
Redstem filaree & 55 & 38.9 & 33.2 & 72 & 0.63 \\
Redstem filaree & 50 & 52.3 & 31.9 & 168 & 0.051 \\
Redstem filaree & 45 & 51.1 & 41.8 & 340 & 0.340 \\
Redstem filaree & 40 & 46.1 & 42.0 & 340 & 0.446 \\
Little mallow & 40 & 39.1 & 54.1 & 340 & 0.051 \\
Common purslane & $45^{*}$ & 37.6 & 16.6 & 96 & 0.033 \\
Redroot pigweed & 40 & 39.6 & 47.4 & 340 & 0.757 \\
\hline
\end{tabular}

Models were created by transforming all treatment and control data to a binary system, with yes (for germination) or no (for no germination). Logistic models were selected as they had a better fit than other regression models. Models were created in JMP 14.0 (SAS Institute, Cary, NC, USA) using a binomial logistic regression model

$$
\mathrm{G}_{\mathrm{t}}=1-\left(1 /\left(1+\mathrm{e}^{\left.-\mathrm{b}_{0}+\mathrm{b}_{1}^{*}\right)}\right)\right)(\text { eq. } 1)
$$

where $\mathrm{G}_{\mathrm{t}}=$ germination rate after time hours $(\mathrm{h})$ exposure to a certain temperature $(\mathrm{t}), \mathrm{b}_{0}=\mathrm{y}$-intercept (log odds), and $\mathrm{b}_{1}=$ line gradient (log odds). $\mathrm{R}^{2}$ was calculated using normalized version of pseudo $\mathrm{R}^{2}$ (Nagelkerke 1991).

\subsection{Results}

\subsubsection{Thermal Death}

Redstem filaree was not affected by heat treatments of $60^{\circ} \mathrm{C}$ or lower (Table 2.2 and Figure 2.2). After $240 \mathrm{~h}$ of exposure at $60^{\circ} \mathrm{C}$ redstem filaree germinated at similar rates to control tests. Little mallow required constant exposure of 72 hours at $60^{\circ} \mathrm{C}, 240$ hours at $55^{\circ} \mathrm{C}, 340$ hours at $50^{\circ} \mathrm{C}$, and 672 hours at $45^{\circ} \mathrm{C}$ to reduce germination rates to 
zero or near zero (Table 2.3). Little mallow was unaffected after 340 hours of exposure to $40^{\circ} \mathrm{C}$ (Table 2.2). Common purslane required constant exposure of 4 hours at $60^{\circ} \mathrm{C}, 68$ hours at $55^{\circ} \mathrm{C}$, and 168 hours at $50^{\circ} \mathrm{C}$ to reduce germination rates to zero. Exposure to 45 and $40^{\circ} \mathrm{C}$ had no negative effect on common purslane germination as purslane was found germinating inside microcosms at temperatures up to $45^{\circ} \mathrm{C}$. Redroot pigweed required constant exposure of 2 hours at $60^{\circ} \mathrm{C}, 6$ hours at $55^{\circ} \mathrm{C}, 72$ hours at $50^{\circ} \mathrm{C}$, and 240 hours at $45^{\circ} \mathrm{C}$ to achieve zero percent germination. Temperatures of $40^{\circ} \mathrm{C}$ did not reduce redroot pigweed germination (Table 2.2).

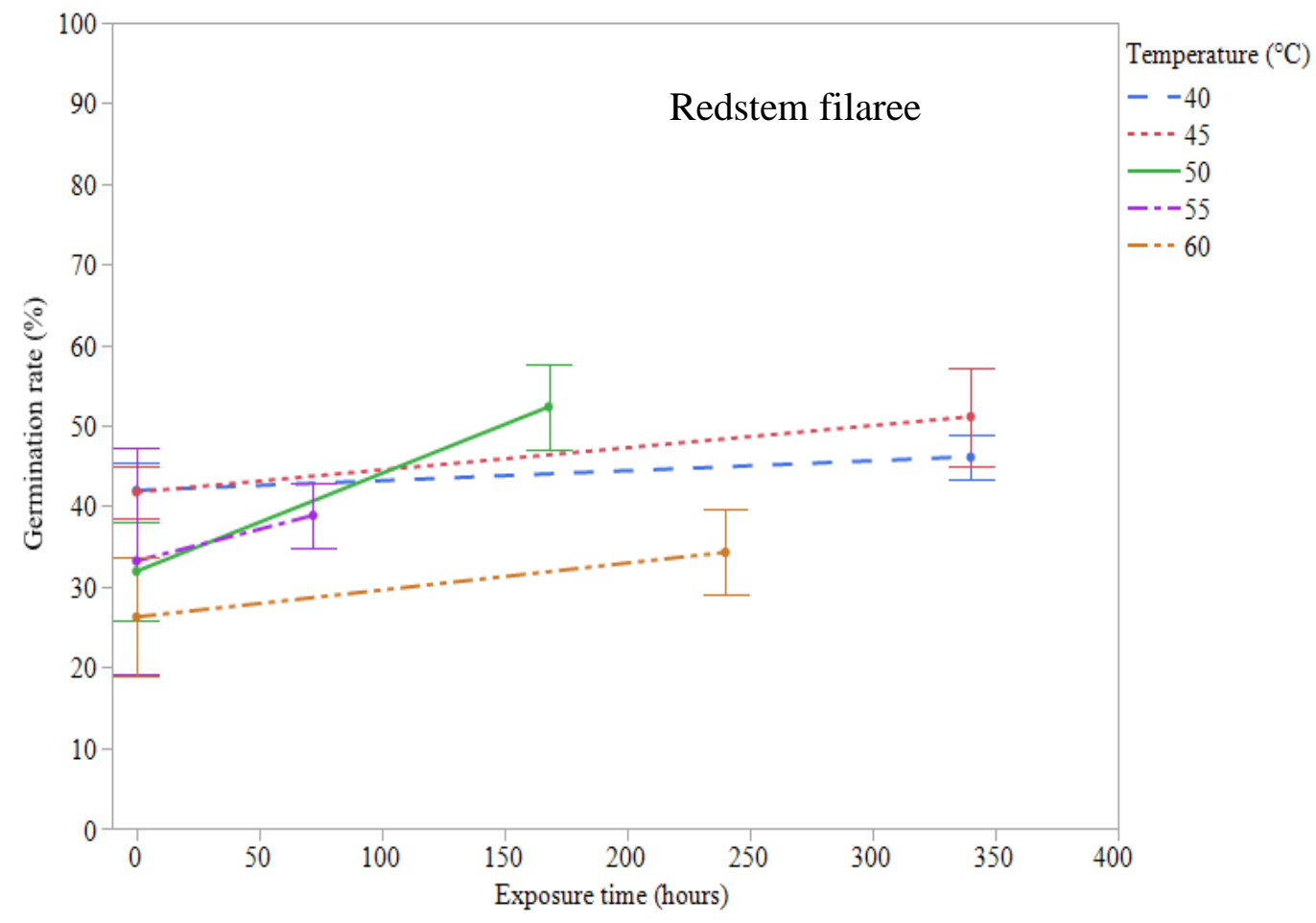

Figure 2.2: Treatment and Control Germination Rates \pm Standard Error (\%) for Redstem Filaree for Experiments at the Longest Time Tested at $40^{\circ} \mathrm{C}($ Blue $), 45^{\circ} \mathrm{C}($ Red $), 50^{\circ} \mathrm{C}($ Green $), 55^{\circ} \mathrm{C}$ (Purple) and $60^{\circ} \mathrm{C}($ Orange $)$. 
All temperatures tested were able to reduce germination rates to zero for nettleleaf goosefoot, annual sowthistle, and bristly oxtongue. Nettleleaf goosefoot required constant exposure of 2 hours at $60^{\circ} \mathrm{C}, 4$ hours at $55^{\circ} \mathrm{C}, 72$ hours at $50^{\circ} \mathrm{C}, 168$ hours at $45^{\circ} \mathrm{C}$, and 432 hours at $40^{\circ} \mathrm{C}$ to reduce germination to zero or almost zero (Table 2.3). Temperature had similar effects on bristly oxtongue and annual sowthistle reducing germination rates to zero in 0.25 hours at $60^{\circ} \mathrm{C}, 1$ to 2 hours at $55^{\circ} \mathrm{C}, 4$ hours at $50^{\circ} \mathrm{C}$. At $40^{\circ} \mathrm{C}$, annual sowthistle required 40 hours and bristly oxtongue required 24 hours to reduce weed germination to $0 \%$ (Table 2.3 ).

Table 2.3: Number of Hours at All Temperatures Tested Required for 0\% Germination of Different Weed Seeds. N/a=Species not affected by this temperature. *=Complete mortality not achieved, 1 or 2 seeds still viable at temperature

\begin{tabular}{cccccc}
\hline & \multicolumn{5}{c}{ Temperature $\left({ }^{\circ} \mathrm{C}\right)$} \\
\hline & 60 & 55 & 50 & 45 & 40 \\
\hline Redstem filaree & N/a & N/a & N/a & N/a & N/a \\
Little mallow & 74 & $240^{*}$ & 340 & $672^{*}$ & N/a \\
Common purslane & 4 & 68 & 168 & N/a & N/a \\
Redroot pigweed & 2 & 6 & 72 & 240 & N/a \\
Nettleleaf goosefoot & 2 & 4 & $72^{*}$ & 196 & 432 \\
Bristly oxtongue & 0.25 & 1 & 6 & 40 & 48 \\
Annual sowthistle & 0.25 & 2 & 6 & 24 & 48 \\
\hline
\end{tabular}

\subsubsection{Tetrazolium Staining}

Tetrazolium staining was used to validate seed germination results and subsequent model generation (Table 2.4). Seed viability after undergoing tetrazolium testing ranged from 0 to $8.57 \%$ across all species and temperatures. Little mallow had the highest percentage of viable non-germinated seed at 8.57 percent at both $50^{\circ} \mathrm{C}$ and $55^{\circ} \mathrm{C}$. Nettleleaf goosefoot also had higher numbers of viable non-germinated seeds than other species $(2.8$ to $7.1 \%)$. Annual sowthistle, bristly oxtongue and redroot pigweed had lower 
viability of non-germinated seeds ( $(0.0$ to $3.3 \%)$. No models were generated for redstem filaree, so tetrazolium testing was not conducted on this species. Overall, low viability results after tetrazolium staining indicate that germination tests were accurate. Therefore, tetrazolium tests were not incorporated into models.

Table 2.4: Percentage of Viable Seeds at Each Temperature Treatment After Undergoing Tetrazolium Staining.

\begin{tabular}{cccccc}
\hline & \multicolumn{5}{c}{ Temperature $\left({ }^{\circ} \mathrm{C}\right)$} \\
\hline & 60 & 55 & 50 & 45 & 40 \\
\hline Annual sowthistle & $0.00 \%$ & $0.00 \%$ & $3.33 \%$ & $2.22 \%$ & $0.00 \%$ \\
Bristly oxtongue & $0.00 \%$ & $0.00 \%$ & $0.00 \%$ & $2.22 \%$ & $0.00 \%$ \\
Redroot pigweed & $3.33 \%$ & $0.00 \%$ & $3.13 \%$ & $0.00 \%$ & $\mathrm{n} / \mathrm{a}$ \\
Nettleleaf goosefoot & $0.00 \%$ & $2.78 \%$ & $7.14 \%$ & $5.66 \%$ & $2.44 \%$ \\
Little mallow & $0.00 \%$ & $8.57 \%$ & $8.57 \%$ & $0.00 \%$ & $\mathrm{n} / \mathrm{a}$ \\
\hline
\end{tabular}

\subsubsection{Logistic Regression Models}

Logistic regression models (Figures 2.3-2.8) were created for all species and temperatures tested, except temperatures where seeds were not affected by heat treatment. Additionally, no models were created for annual sowthistle and bristly oxtongue at $60^{\circ} \mathrm{C}$ as models were non-significant due to seed mortality occurring in 15 min. The effects of all other models were significant at a level of $p<0.0001$. For all species an increase in temperature led to decreases in time required to reduce germination rates.

Different species responded differently to temperatures generated by solarization. The cool-season species annual sowthistle and bristly oxtongue were the most susceptible to solarization temperatures. Warm-season species nettleleaf goosefoot, redroot pigweed, and common purslane were more tolerant of solarization temperatures than cool-season species, but less tolerant than hard-seeded species. Common purslane was more tolerant 
than the other two warm-season species. Hard-seeded weed species, little mallow and redstem filaree were the least susceptible to solarization temperatures.

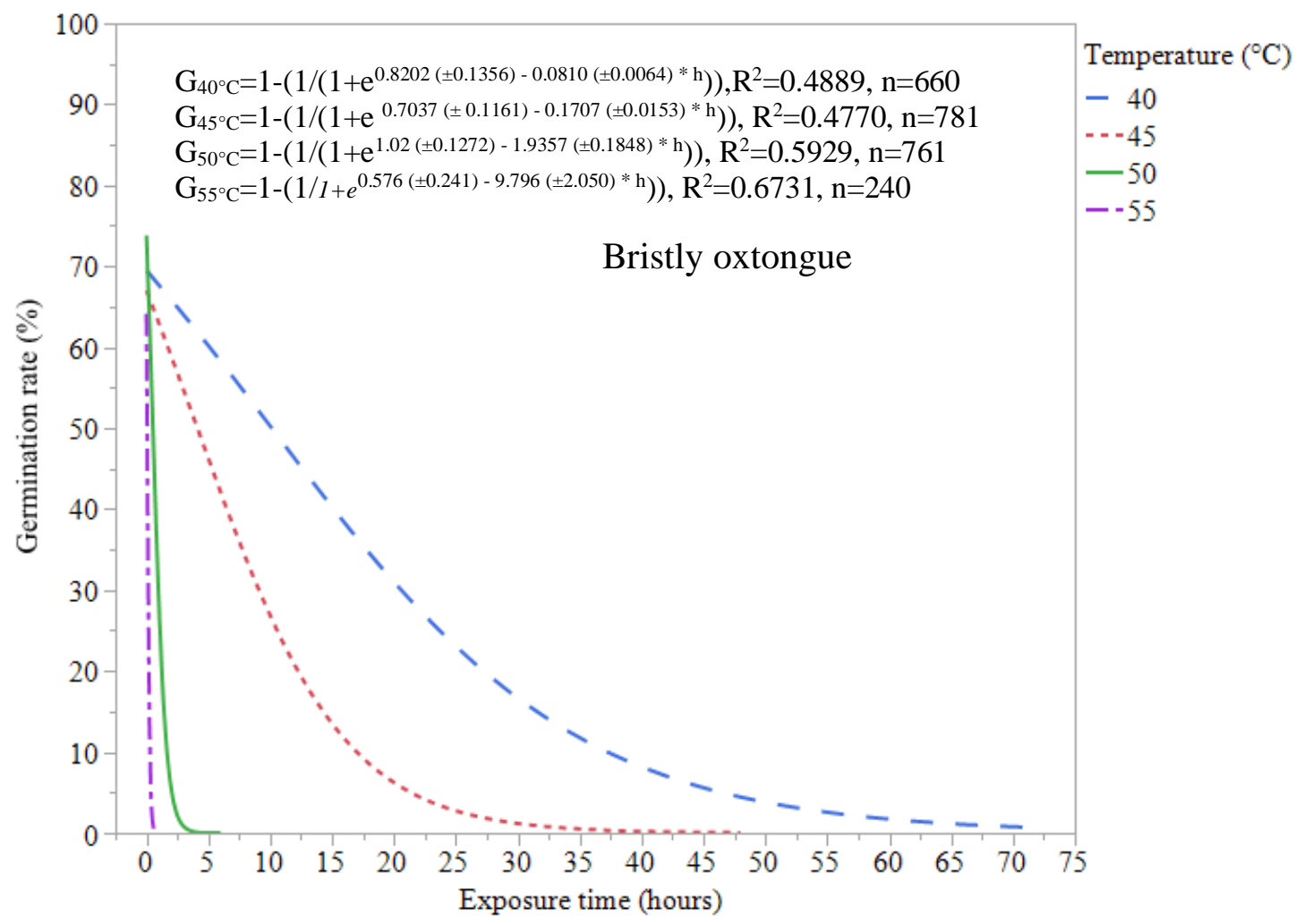

Figure 2.3: Logistic Regression Models, $G_{t}=1-\left(1 /\left(1+e^{b 0-b 1^{*} h}\right)\right)$ of Bristly Oxtongue at $40^{\circ} \mathrm{C}($ Blue $), 45^{\circ} \mathrm{C}$ $($ Red $), 50^{\circ} \mathrm{C}$ (Green), And $55^{\circ} \mathrm{C}$ (Purple). $G_{t}=$ germination rate after time hours $(h)$ exposure to a certain temperature $(t), b_{0}=y$-intercept ( $\log$ odds), and $b_{1}=$ line gradient ( $\log$ odds). 


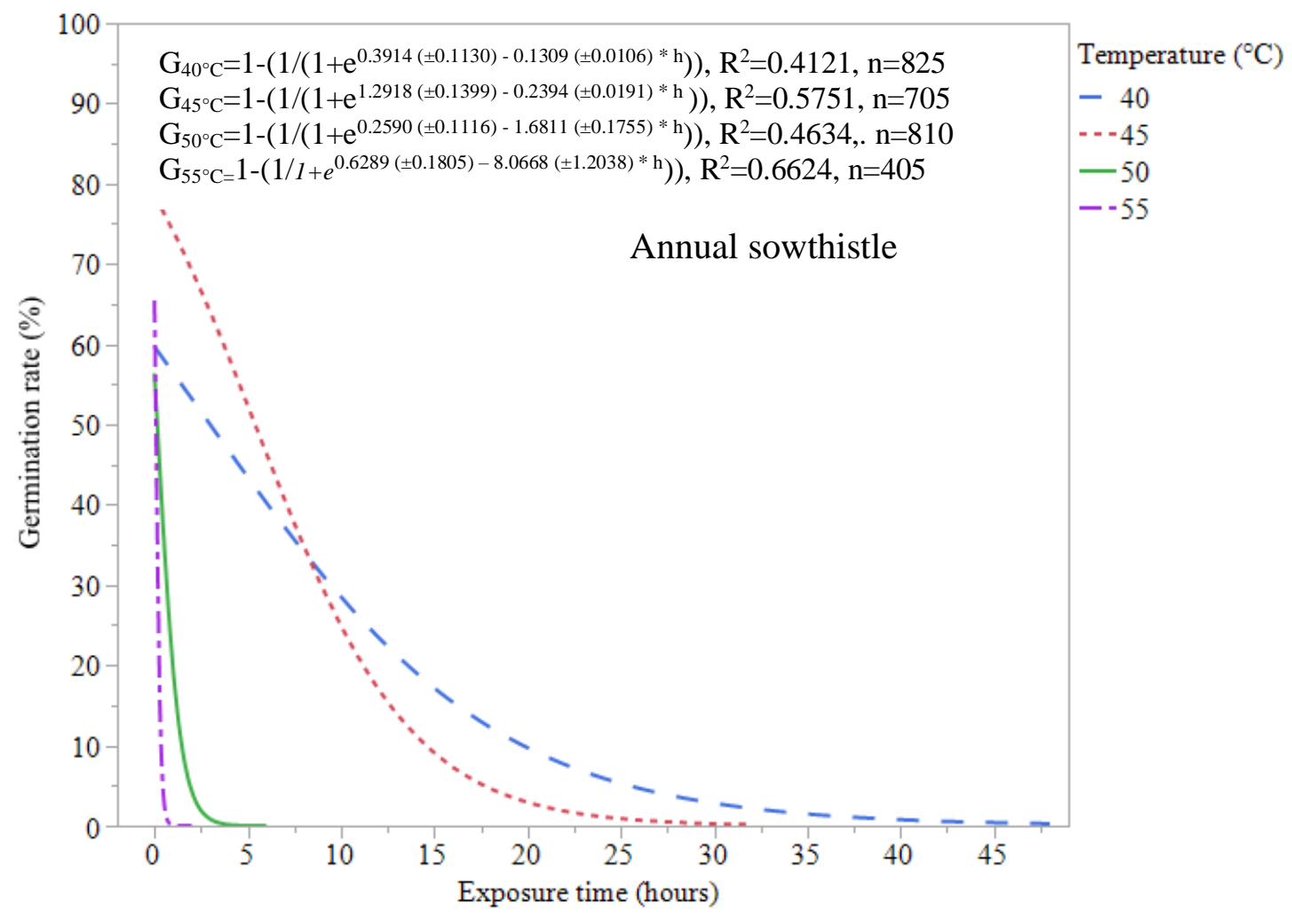

Figure 2.4: Logistic Regression Models, $G_{t}=1-\left(1 /\left(1+e^{b 0-b 1^{* h}}\right)\right)$ of Annual Sowthistle at $40^{\circ} \mathrm{C}($ Blue $)$, $45^{\circ} \mathrm{C}(\mathrm{Red}), 50^{\circ} \mathrm{C}(\mathrm{Green})$, And $55^{\circ} \mathrm{C}$ (Purple). $G_{t}=$ germination rate after time hours $(h)$ exposure to a certain temperature $(t), b_{0}=y$-intercept $\left(\log\right.$ odds), and $b_{1}=$ line gradient $(\log$ odds). 


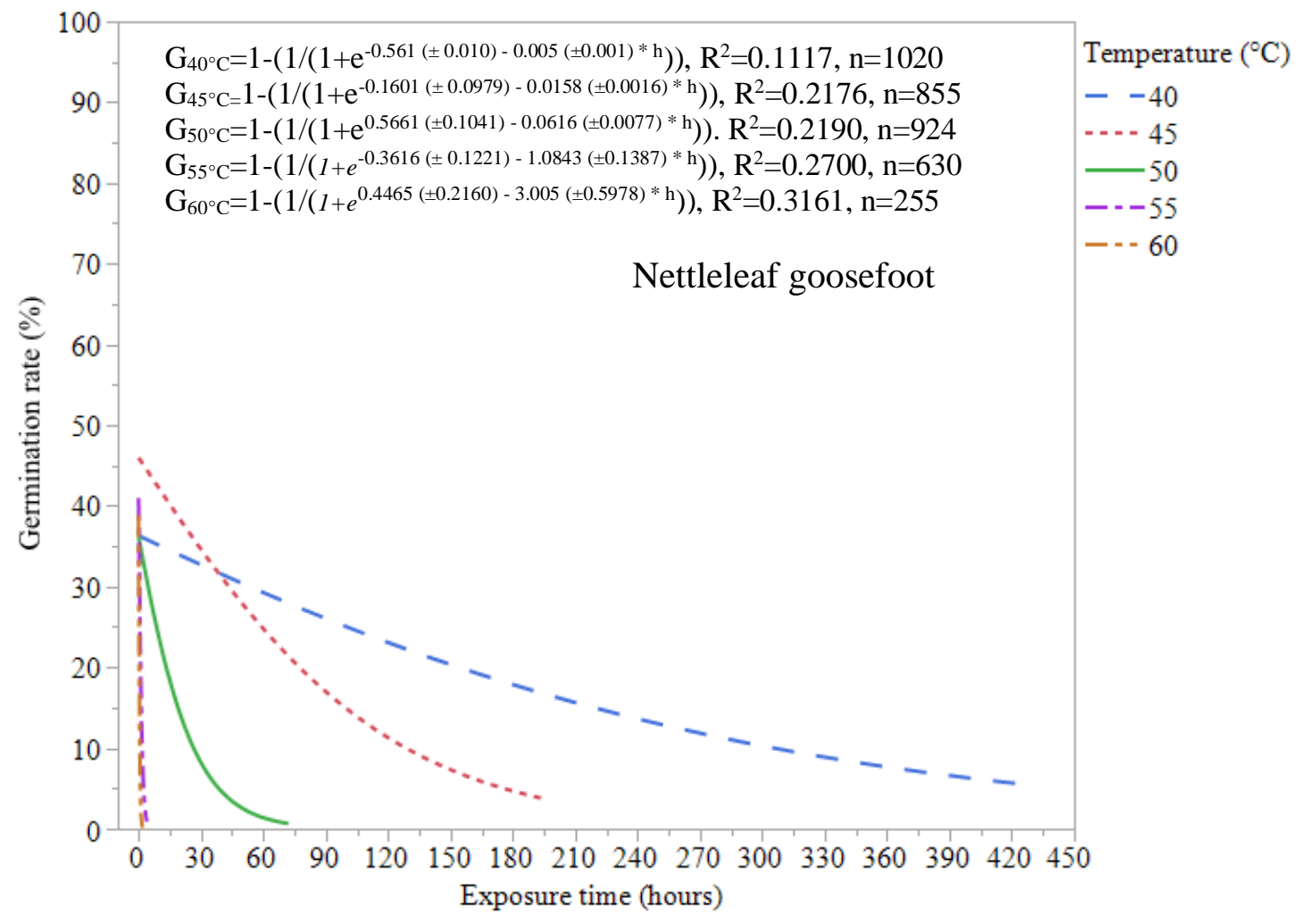

Figure 2.5: Logistic Regression Models, $G_{t}=1-\left(1 /\left(1+e^{b 0-b 1 * h}\right)\right)$ of Nettleleaf Goosefoot at $40^{\circ} \mathrm{C}($ Blue $)$, $45^{\circ} \mathrm{C}(\mathrm{Red}), 50^{\circ} \mathrm{C}\left(\right.$ Green), $55^{\circ} \mathrm{C}\left(\right.$ Purple) And $60^{\circ} \mathrm{C}$ (Orange). $G_{t}=$ germination rate after time hours $(h)$ exposure to a certain temperature $(t), b_{0}=y$-intercept ( $\log$ odds), and $b_{1}=$ line gradient (log odds). 


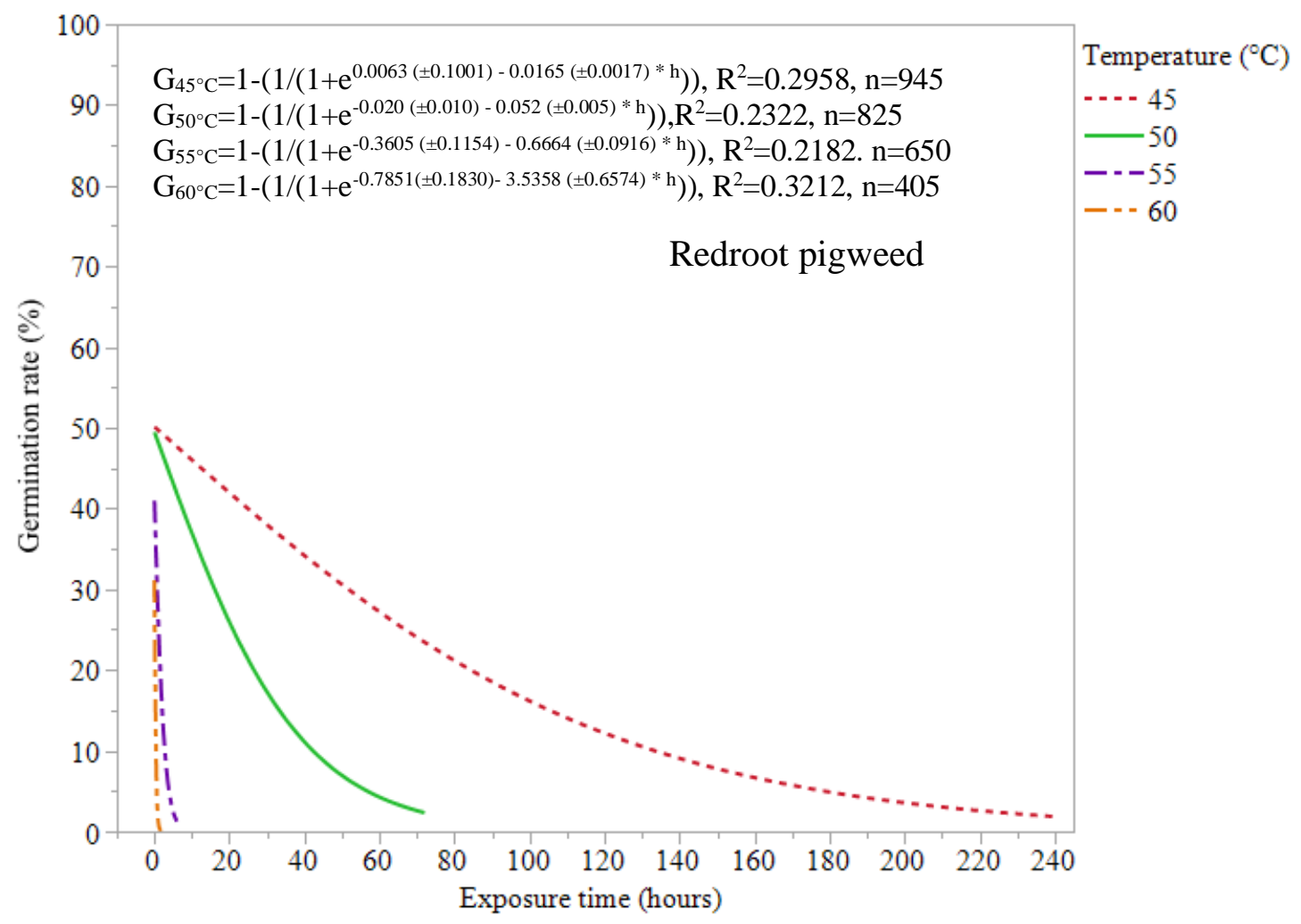

Figure 2.6: Logistic Regression Models, $G_{t}=1-\left(1 /\left(1+e^{b 0-b 1^{*} h}\right)\right)$, of Redroot Pigweed at $45^{\circ} \mathrm{C}(\mathrm{Red}), 50^{\circ} \mathrm{C}$ (Green), $55^{\circ} \mathrm{C}$ (Purple) And $60^{\circ} \mathrm{C}$ (Orange). G=germination rate after time hours $(h)$ exposure to a certain temperature $(t), b 0=y$-intercept $(\log$ odds $)$, and $b 1=$ line gradient $(\log$ odds). 


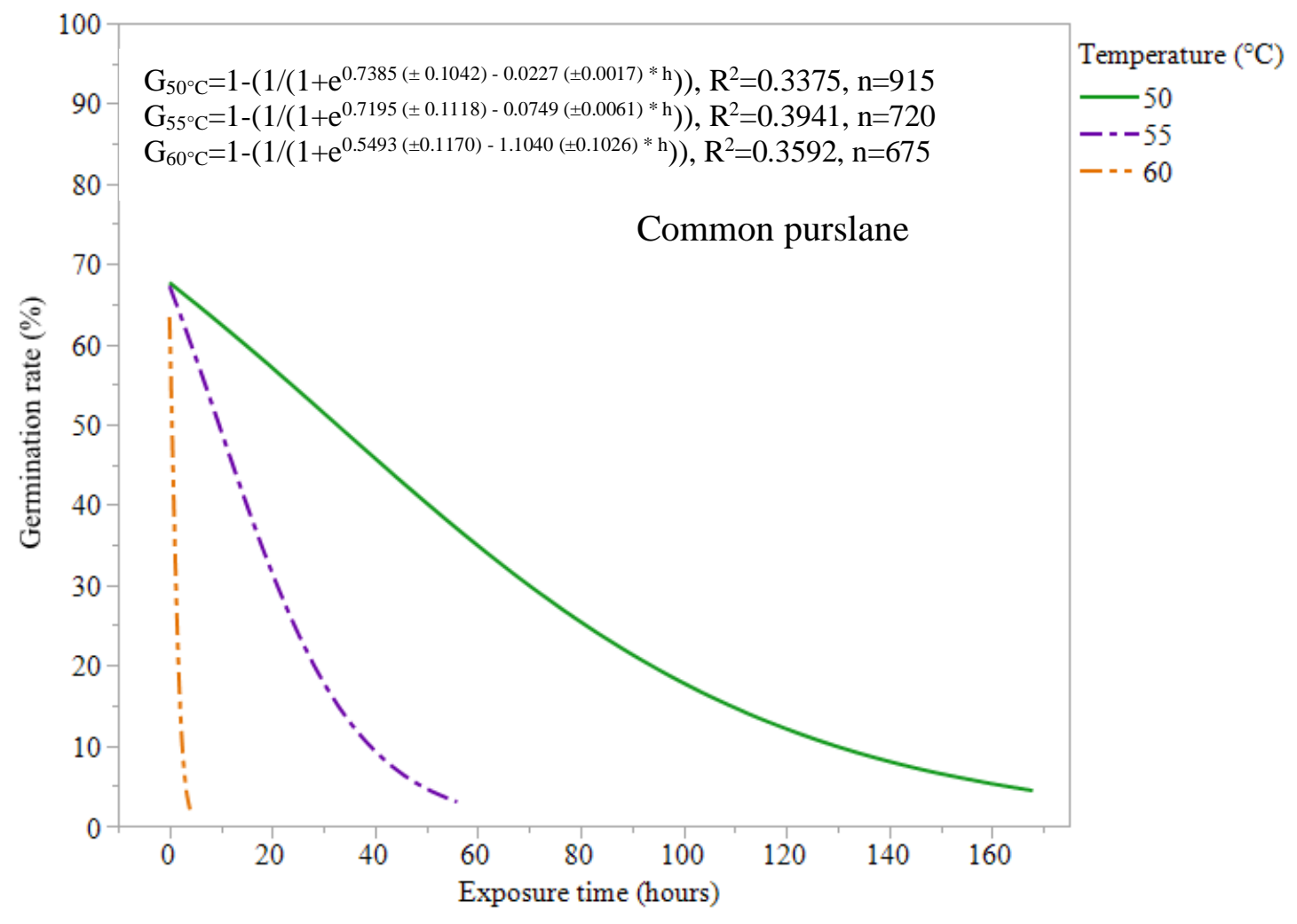

Figure 2.7: Logistic Regression Models, $G_{t}=1-\left(1 /\left(1+e^{b 0-b 1 * h}\right)\right)$ of Common Purslane at $50^{\circ} \mathrm{C}($ Green), $55^{\circ} \mathrm{C}$ (Purple) And $60^{\circ} \mathrm{C}$ (Orange). $G_{t}=$ germination rate after time hours $(h)$ exposure to a certain temperature ( $t), b_{0}=y$-intercept ( $\log$ odds), and $b_{1}=$ line gradient (log odds). 


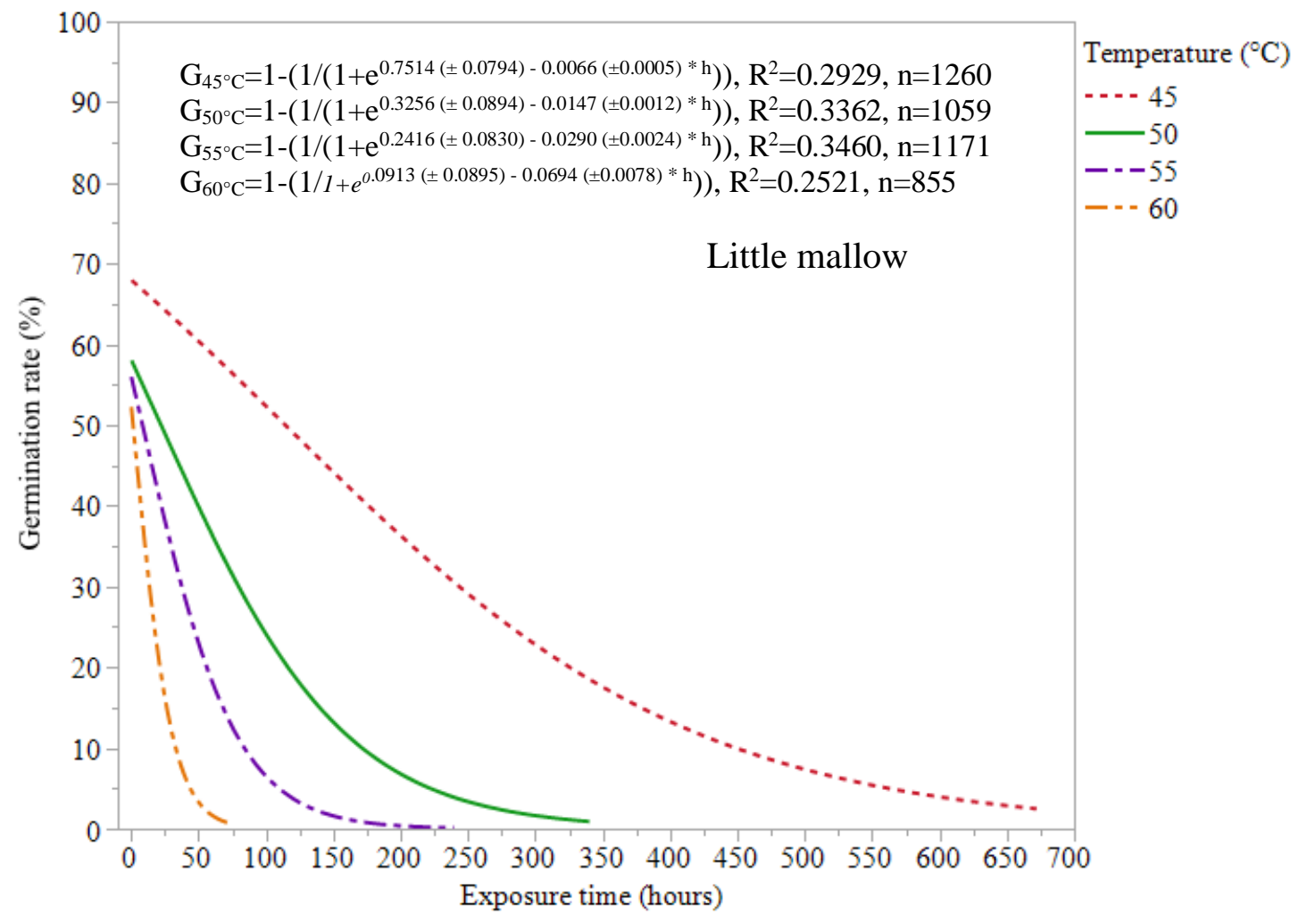

Figure 2.8: Logistic Regression Models, $G_{t}=1-\left(1 /\left(1+e^{b 0-b 1^{* h}}\right)\right)$, Of Little Mallow at $45^{\circ} \mathrm{C}($ Red $), 50^{\circ} \mathrm{C}$ (Green), $55^{\circ} \mathrm{C}$ (Purple) And $60^{\circ} \mathrm{C}$ (Orange). $G_{t}=$ germination rate after time hours $(h)$ exposure to a certain temperature $(t), b_{0}=y$-intercept $\left(\log\right.$ odds), and $b_{l}=$ line gradient (log odds).

The values of $b_{1}$ can be used to compare species (Figures 2.3-2.8). At $45^{\circ} \mathrm{C}$, the $\mathrm{b}_{1}$ of cool-season species bristly oxtongue and annual sowthistle decreased at a rate of 10 to 14 times the $b_{1}$ of nettleleaf goosefoot and redroot pigweed. At $50^{\circ} \mathrm{C}$, the $b_{1}$ of coolseason species decreased at a rate between 27 and 84 times the $b_{1}$ of all warm-season species (pigweed, goosefoot, and purslane) and between 112 and 129 times the $b_{1}$ of little mallow. At $55^{\circ} \mathrm{C}$, the $b_{1}$ of cool-season species decreased at a rate between 7 and 130 times the $b_{1}$ of all warm-season species and between 278 to 337 times the $b_{1}$ of little mallow. At $60^{\circ} \mathrm{C}$, the $\mathrm{b}_{1}$ of warm-season species decreased at a rate of 16 to 51 times the $b_{1}$ of little mallow. 
The LD50 and LD90 of the models can also help distinguish the differences in solarization temperatures' effect on different weed species. By looking at the LD50 and LD90 and their confidence intervals, differences in response to solarization temperatures can be determined (Table 2.5). At all temperatures tested $\left(45,50,55\right.$ and $\left.60^{\circ} \mathrm{C}\right)$ little mallow has the longest LD50 and LD90. Common purslane had the next longest LD50 and LD90. The confidence intervals of common purslane overlap with nettleleaf goosefoot and pigweed for both the LD50 and LD90 at $50^{\circ} \mathrm{C}$ and $55^{\circ} \mathrm{C}$ indicating similar susceptibilities at these temperatures. At $60^{\circ} \mathrm{C}$, no overlap occurred between confidence intervals of purslane and other warm-season species. Nettleleaf goosefoot and pigweed had similar LD50's and LD90's at all temperatures except the LD90 at $55^{\circ} \mathrm{C}$ and at $40^{\circ} \mathrm{C}$ where pigweed was not affected. Annual sowthistle and bristly oxtongue had lower LD50 and LD90 values than all other weed species. Bristly oxtongue was less susceptible than annual sowthistle at lower temperatures having a longer LD50 and LD90 at $40^{\circ} \mathrm{C}$ and a longer LD90 at $45^{\circ} \mathrm{C}$. 
Table 2.5: Time (Hours) Required for 50\% Mortality (LD50) and 90\% Mortality (LD90) According to Logistic Regression Models. LD50 and LD90 were calculated by finding time required to reduce germination rate at 0 hours of exposure by $50 \%$ and $90 \% .95 \%$ confidence intervals calculated for each LD50 and LD90.

\begin{tabular}{lccccc}
\hline Species & $\begin{array}{c}\text { Temperature } \\
\left({ }^{\circ} \mathrm{C}\right)\end{array}$ & $\begin{array}{c}\text { LD50 } \\
\text { (hours })\end{array}$ & $\begin{array}{c}95 \% \text { CI } \\
( \pm \text { hours })\end{array}$ & $\begin{array}{c}\text { LD90 } \\
\text { (hours })\end{array}$ & $\begin{array}{c}95 \% \text { CI } \\
( \pm \text { hours })\end{array}$ \\
\hline Little mallow & 45 & 215 & 23.1 & 513 & 54.0 \\
& 50 & 82.9 & 10.9 & 211 & 24.2 \\
Bristly oxtongue & 55 & 40.8 & 5.58 & 105 & 13.1 \\
& 60 & 16.3 & 2.81 & 43.1 & 7.07 \\
Common purslane & 40 & 17.9 & 2.62 & 42.2 & 4.64 \\
& 45 & 8.15 & 1.17 & 19.6 & 2.47 \\
& 50 & 0.81 & 0.12 & 1.84 & 0.25 \\
Nettleleaf goosefoot & 55 & 0.14 & 0.06 & 0.33 & 0.10 \\
& 50 & 62.1 & 7.11 & 148 & 15.1 \\
& 55 & 18.7 & 2.55 & 44.7 & 5.22 \\
& 40 & 1.19 & 0.17 & 2.94 & 0.38 \\
& 45 & 176 & 31.0 & 508 & 85.5 \\
Redroot pigweed & 50 & 15.3 & 3.23 & 44.1 & 7.89 \\
& 55 & 0.91 & 0.2 & 2.57 & 0.46 \\
& 60 & 0.32 & 0.13 & 0.92 & 0.25 \\
& 45 & 66.7 & 10.3 & 179 & 22.2 \\
& 50 & 21.2 & 3.46 & 57.0 & 8.34 \\
& 55 & 1.49 & 0.32 & 4.19 & 0.79 \\
& 60 & 0.25 & 0.09 & 0.75 & 0.19 \\
& 40 & 9.52 & 1.42 & 24.0 & 2.78 \\
& 45 & 7.22 & 0.89 & 15.7 & 1.69 \\
& 50 & 0.71 & 0.13 & 1.83 & 0.28 \\
& 55 & 0.17 & 0.05 & 0.41 & 0.09 \\
\hline
\end{tabular}

\subsection{Application to Field Conditions}

Models created simplify solarization conditions and act under a multitude of assumptions. Field conditions result in diurnal temperature fluctuations, unlike constant temperatures used to generate models. However, experiments on black mustard (Brassica nigra L.) simulating solarization conditions using constant temperatures generated similar models to those using diurnal temperature fluctuations (Dahlquist-Willard et al. 2016). 
This demonstrates that constant temperature models can be used to simulate responses to solarization despite not accounting for diurnal temperature fluctuations (DahlquistWillard et al. 2016). The advantage of diurnal fluctuating models is that they are easier to apply to field conditions (Dahlquist-Willard et al. 2016). The disadvantage is that these models can be complicated as they need to account for each time and temperature increment along the curve (Dahlquist et al. 2007).

The usefulness of logistic regression models generated in this study pertain to estimating the amount of time needed to kill various weed species at various temperatures achievable by solarization. By observing the cumulative number of hours that are above a certain temperature threshold growers can estimate the amount of time needed for solarization to be effective (Peachey et al. 2001). To more accurately apply models to field conditions temperatures that fall between tested thresholds need to be accounted for. Methodology for accounting for temperatures between tested thresholds have been described in other papers (Dahlquist et al. 2007). This can give growers a simplified heat accumulation model which they can use to aid their decision regarding solarization treatments.

Other factors not accounted for in laboratory experiments can contribute to differences in field mortality. Models do not account for physiological weakening of seed coats which occurs at solarization temperatures (Rubin and Benjamin 1984). This can cause germination of dormant seeds and subsequent mortality as seedlings are exposed to high temperatures in shallower layers of the soil once they germinate (Egley 1990). Higher temperatures also increase the activity of volatile allelochemicals and biofumigants which can reduce weed seed viability (Gamliel et al. 2000). Incorporating 
organic amendments into the soil before solarizing, also known as biosolarization, can further increase the activity of volatile chemicals and organic acids leading to increased toxicity against weed seeds (Gamliel and Stapleton 1993a, Simmons et al. 2016). Lastly, high temperatures can make weed seeds more susceptible to antagonistic soil organisms (Stapleton and DeVay 1986). As lab experiments were conducted in semi-sterile conditions without incorporation of organic amendments, results obtained in this study may over- or under-estimate weed survival under various solarization conditions.

Models did not account for differing soil conditions which can affect heat dispersion throughout the soil and efficacy of solarization against weed seeds (Marshall et al. 2013). Seeds were tested in coarse sand. Coarse soils were found to require slightly longer times to achieve seed mortality than finer soils at $60^{\circ} \mathrm{C}$ and $70^{\circ} \mathrm{C}$ (Melander and Kristensen 2011). As such, shorter times may be needed to kill weed seeds in finer soils than those used in this study.

Differences in susceptibility to solarization appear to be based on the thickness of the seed coat and germination season of seeds. Our results are in agreement with previous findings that have shown differences between winter and summer annuals response to solarization (Dahlquist et al. 2007, Elmore et al. 1997). Differences in susceptibility to solarization between winter and summer annuals may be due to the presence of heat shock proteins which appear to be involved in the protection of seeds from heat. These proteins may be more prevalent in species that experience high temperatures during germination (Coca et al. 1994, Medina and Cardemil 1993).

Field and laboratory studies have shown that hard-seeded weed species tend to be resistant to solarization although that response might be variable (Elmore et al. 1997, 
Horowitz et al. 1983, Rubin and Benjamin 1984). Some hard-seeded species such as velvetleaf (Abutilon theophrasti L.) are more susceptible than many warm-season-species (Egley 1990, Horowitz and Taylorson 1983). Furthermore, certain legumes such as Mediterranean sweet clover (Melilotus sulcatus L.) and Medicago spp.(L.) are completely resistant to solarization due to their thick seed coat (Candido et al. 2011, El-Keblawy and Al-Hamadi 2009, Powles et al. 1988, Rubin and Benjamin 1984). Similar trends were observed in this study, where redstem filaree is not affected by solarization, but little mallow is affected after long exposure times even at lower temperatures of $45^{\circ} \mathrm{C}$.

Results for species tested in this experiment support previously collected field data with a few contradictions. Annual sowthistle, redroot pigweed, and nettleleaf goosefoot have been successfully controlled by solarization under field conditions (Stapleton 1996). Common purslane has been shown to be resistant to solarization, particularly in marginal solarization conditions (DeVay et al. 1991, El-Keblawy and AlHamadi 2009, Samtani et al. 2012). Models generated in this study support these field tests as purslane was unaffected at temperatures of $45^{\circ} \mathrm{C}$ or below. Likewise, little mallow has only been partially controlled under marginal solarization conditions with max temperatures $<45^{\circ} \mathrm{C}$ (Samtani et al. 2012). However, mallow has been controlled by solarization in other studies (El-Keblawy and Al-Hamadi 2009). Erodium spp. (L.) are considered susceptible to solarization (Porter and Merriman 1983). This contradicts our study as redstem filaree was found to be completely resistant to solarization. Potential reasons for this disagreement include previously mentioned factors which can increase weed mortality not accounted for in the model or alternatively, seeds surviving the solarization process, but not germinating during timing of field experiment due to 
secondary dormancy or other factors. It is important to further test all seeds under field conditions, particularly redstem filaree, which has contradictory results and bristly oxtongue which has not been tested under field conditions.

\subsection{Conclusions}

Logistic regression models help us understand the thermal requirements for weed seed control and provide a quick tool to compare tolerance of different weed species. In the field, these models can provide guidelines to growers on whether solarization can manage their weed populations. Further research should be directed towards validating laboratory tests under field conditions, accounting for different environmental factors in laboratory experiments and testing more weed species. Additional research can look at combining weed seed models with solarization temperature models such as those used in Marshall et al. (2013). These models could be combined and developed into user friendly guidelines to help growers determine whether solarization is appropriate for their field. 
Chapter 3

\section{EFFECT OF SUDANGRASS COVER CROP RESIDUES AND SOIL SOLARIZATION ON WEED AND PATHOGEN POPULATIONS IN ORGANIC STRAWBERRY PRODUCTION.}

\subsection{Introduction}

Soil solarization has been effectively used for weed control in California's deserts and central valley where solar radiation and ambient air temperatures are high (Stapleton et al. 2008a, 2008b). Solarization has also effectively controlled the important strawberry pathogen Verticillium dahliae (Kleb.) in multiple cropping systems in various regions around the world (Berbegal et al. 2008, Lopez-Escudero and Blanco-Lopez 2001, Pullman et al. 1981b). However, it has had mixed effectiveness when used in strawberry production systems in coastal California where ambient air temperatures are lower and solar radiation can be obscured by fog (Daugovish et al. 2016, Hartz et al. 1993, Samtani et al. 2012).

One method of enhancing the effects of soil solarization, and potentially expanding the use of solarization to cooler regions is biosolarization. Biosolarization involves the heating of organic amendments using soil solarization, combining biofumigation with solarization (Gamliel et al. 2000). Biosolarization is very similar to anaerobic soil disinfestation, an organic soil disinfestation method which has shown promise for use in California strawberry production (Mazzola et al. 2018, Muramoto et al. 2016, Shennan et al. 2018), except that lethal heating is not achieved via anaerobic soil disinfestation and biosolarization attempts to maintain slightly aerobic conditions (Stapleton et al. 2016). 
Multiple studies have documented success controlling pathogens at sublethal solarization temperatures when organic amendments are incorporated into the soil (Blok et al. 2000, Núñez-zofío et al. 2011, Tjamos and Fravel 1995). Biosolarization of fresh chicken manure and dried olive pomace in Spanish strawberry production has effectively controlled populations of Macrophomina phaseolina (Tassi) Goid. and Fusarium oxysporum f. sp. fragariae Winks and Williams. leading to increased yields over nontreated fields (Chamorro et al. 2015a, 2015b, Domínguez et al. 2014, 2016).

Biosolarization of plant residues have primarily been restricted to plants in the Brassicaceae family, composts, or plant processing waste products. These treatments are effective (Achmon et al. 2016, Gamliel and Stapleton 1993b, Simmons et al. 2013), but it is worth looking at other plant residues to determine their efficacy in combination with soil solarization. Poaceae species have potential for use in biosolarization and have successfully reduced Meloidogyne spp., Sclerotium rolfsii Sacc. and Pythium ultimum Trow. populations in micro-reactor experiments simulating marginal solarization conditions (Stapleton et al. 2010). Sorghum spp. are popular summer cover crops that have been used as biofumigants against root knot nematodes (Curto et al. 2012). Plant residues from Sorghum spp. contain dhurrin, which hydrolyzes into a biotoxic hydrogen cyanide gas during its decomposition (Widmer and Abawi 2000, 2002).

Incorporation of sudangrass residues has shown the ability to reduce populations of $V$. dahliae and reduce disease incidence of Verticillium wilt in potatoes (Solanum tuberosum L.) improving yields over controls (Davis et al. 2004, MacGuidwin et al. 2012). When combined with solarization, sudangrass residues have reduced both annual bluegrass emergence (Peachey et al. 2001) and reduced populations of $V$. dahliae, an 
important strawberry pathogen, by over 99\% (Pinkerton et al. 2000). Although, solarization and sudangrass residues have been effective against a variety of pathogens and weeds, it has yet to be determined if they can reduce pathogen and weed pressures along California's central coast in strawberry production systems. Strawberries are very susceptible to pathogens such as $V$. dahliae, with as much has 1-2 microsclerotia per gram able to cause 50\% disease incidence (Harris and Yang 1996).

The objectives of this project are:

1) to determine if soil solarization can reduce weed and pathogen pressures and improve plant health and strawberry yields in San Luis Obispo County,

2) to determine if the effect of sudangrass cover crop residues will increase the effects of soil solarization, and

3) to compare the effects of sudangrass residue mulching vs. incorporation on weed populations, pathogen populations, and strawberry health and yields.

\subsection{Materials and Methods}

\subsubsection{Site Description}

This study was conducted at the Cal Poly Organic Farm in San Luis Obispo, California $\left(35^{\circ} 18^{\prime} 16.90^{\prime \prime} \mathrm{N} 120^{\circ} 40^{\prime} 19.83^{\prime \prime} \mathrm{W}\right)$. The soil texture of the field is clay loam. Composite soil samples for chemical analysis were taken on 20 May 2019 (Table 3.1). Cropping history of the fields includes organic strawberry and vegetable production. Immediately before this project the field was cropped with romaine lettuce (Lactuca sativa L.). Lettuce residue was mowed and incorporated in late winter. To prepare for planting the cover crop, the field was ripped and disked twice in April 2018. 
Table 3.1: Soil Properties and Cation Exchange Properties Taken on 21 May on the Cal Poly Organic Farm.

\begin{tabular}{|c|c|}
\hline \multicolumn{2}{|c|}{ Soil properties } \\
\hline Organic Matter $(\%)$ & 4.05 \\
\hline Soil pH & 7.5 \\
\hline $\mathrm{NO}_{3}{ }^{-}(\mathrm{ppm})$ & 28.4 \\
\hline $\mathrm{PO}_{4}(\mathrm{ppm})$ & 21.45 \\
\hline $\mathrm{K}(\mathrm{ppm})$ & 319.85 \\
\hline $\mathrm{Mg}(\mathrm{ppm})$ & 834.7 \\
\hline $\mathrm{Ca}(\mathrm{ppm})$ & 2622.45 \\
\hline $\mathrm{S}(\mathrm{ppm})$ & 8.75 \\
\hline $\mathrm{Zinc}(\mathrm{ppm})$ & 4 \\
\hline $\mathrm{Mn}(\mathrm{ppm})$ & 15.15 \\
\hline $\mathrm{Copper}(\mathrm{ppm})$ & 6.2 \\
\hline $\mathrm{Iron}(\mathrm{ppm})$ & 47.4 \\
\hline $\mathrm{Boron}(\mathrm{ppm})$ & 1.05 \\
\hline $\mathrm{SO}(\mathrm{ppm})$ & 26.25 \\
\hline $\mathrm{Cl}(\mathrm{ppm})$ & 19.35 \\
\hline $\mathrm{Na}(\mathrm{ppm})$ & 58.3 \\
\hline $\mathrm{EC}(\mathrm{mmhos} / \mathrm{cm})$ & 0.5 \\
\hline \multicolumn{2}{|c|}{$\mathrm{Cation}$ exchange capacity } \\
\hline $\mathrm{K}(\%)$ & 3.85 \\
\hline $\mathrm{Mg}(\%)$ & 32.9 \\
\hline $\mathrm{Ca}(\%)$ & 61.95 \\
\hline $\mathrm{Na}(\%)$ & 1.15 \\
\hline $\mathrm{H}(\%)$ & 0 \\
\hline Total CEC (cmol $/ \mathrm{kg})$ & 21.15 \\
\hline
\end{tabular}




\subsubsection{Plot Design}

The field experiment tested two factors: different sudangrass residue treatments and soil solarization. The experimental field was organized according to a split plot design with 4 replications. The main plot was sudangrass treatment and the sub-plot factor was solarization. Thus, each main plot (sudangrass) was divided into one solarized plot and one non-solarized plot. Plots were laid out into 4 blocks and randomized within each block. Plots were $1.5 \mathrm{~m}$ wide by $6 \mathrm{~m}$ long. There was $1.5 \mathrm{~m}$ buffer zone between each plot to allow for equipment operation.

\subsubsection{Cover Crop Planting}

Sudangrass was planted on 11 May 2018. 'Piper' sudangrass was drilled $3 \mathrm{~cm}$ deep in $1.5 \mathrm{~m}$ x $6 \mathrm{~m}$ rows corresponding with cover cropped plots at a density of $45 \mathrm{~kg}$ per hectare using a Schmeiser grain drill (Schmeiser vineyard series $2^{\text {nd }}$ generation-series 98, T.J. Schmeiser Co. Inc., Selma, CA, USA). The seed germination rate in a lab setting was $75.2 \%$. The actual field germination rate was $48.2 \%$. Immediately after planting the field was fertilized (14-0-1) using a broadcast spreader (Hard Push Spreader p10-500BH, Brinly-Hardy Company, Jeffersonville, IN, USA) at a rate of $67 \mathrm{~kg}$ of nitrogen (N) per hectare. Six weeks after planting $33 \mathrm{~kg}$ of N (14-0-1) per hectare were hand broadcast across all plots. The field was irrigated using a fixed solid set sprinkler system for 30 minutes per week. Starting 5 weeks after planting irrigation was increased to 90 minutes per week. Fields were irrigated at a net application rate of $6 \mathrm{~mm}$ per hour. Watering was stopped a week before mowing the cover crop.

Before mowing, sudangrass biomass and height readings were recorded. Biomass readings were taken using a randomly selected $30 \mathrm{~cm}$ section of one row in each cover 
cropped plot. Biomass samples were placed in paper bags then dried in a forced air convection oven at $70^{\circ} \mathrm{C}$ for 48 hours and then weighed. Additionally, Sudangrass height was determined by measuring the highest point of the sudangrass at 3 different locations in each plot and averaging across each plot.

Sudangrass was chopped and shredded with a tractor drawn flail mower on 17 July 2018. On 19 July residues from sudangrass were incorporated into the soil using a tractor drawn disc. On 23 July two $0.75 \mathrm{~m}$ by $20 \mathrm{~cm}$ inch beds were listed per row. On 25 July two beds originally listed were combined into a single $1 \mathrm{~m}$ wide bed that was raised by $25 \mathrm{~cm}$.

In mulched treatments, sudangrass residue was left on the surface. No beds were created. In solarized, mulched treatments solarizing plastic was laid over the mulched stubble. In-non solarized, mulched treatments sudangrass regrew. Sudangrass was mowed again on 3 September and 14 October 2018 and did not die in mulched, nonsolarized treatments till it winter killed in December.

\subsubsection{Solarization}

On 26 July 2018, 2.4 mil low-density polyethylene plastic (Agfabric 2.4 mil Plastic Covering, WellCo Industries Inc., Corona, CA, USA) was hand applied onto solarized plots. Creation of the beds left furrows in which the edges of plastic were laid. Then plastic was pulled tight, and edges were covered with soil. After applying plastic, fields were irrigated for 72 hours using one line of drip tape till fields reached field capacity. Tarps were left on for 5 weeks and removed on 31 August 2018. Temperatures were monitored using ibutton dataloggers (Ibutton Thermocron F5, Maxim Integrated, San Jose, CA, USA) and echo dataloggers (ECHO EM50 Datalogger and STE 50 Data 
Probe, Decagon Instruments, Pullman, WA, USA) at $5 \mathrm{~cm}$ and $15 \mathrm{~cm}$ depths.

Temperatures were only recorded in 3 of the solarized replications. One replication of a solarized, mulched treatment was excluded from the study as a result of uneven solarization due to unlevel field preparation.

\section{$\underline{3.2 .5 \text { Strawberry Planting }}$}

Before planting, two lines of drip tape were laid in beds. $100 \mathrm{~kg}$ per hectare of 85-1 fertilizer was applied to all beds and incorporated into the top $5 \mathrm{~cm}$ of the soil surface. Beds were then covered with 6 mil black polyethylene plastic. On each bed, 1.33 $\mathrm{m}$ was left as a weedy check, and strawberries were planted in $16 \times 4 \mathrm{ft}$ beds. Fields were pre-irrigated the day before planting. Strawberries crowns, 'Sweet Anne' (Lassen Canyon Nursery, Redding, CA, USA) were planted on beds with 2 rows of plants per bed on 23 and 24 October. Rows were spaced 12 inches apart and plants were spaced 12 inches apart within rows. Strawberries were sprinkler irrigated for the first 4 weeks to get plants established then drip irrigated afterwards. From December through February, plots were side dressed once per month with $12 \mathrm{~kg}$ of N/per hectare using 8-5-1 fertilizer. Every two weeks starting in March, fertilizer was applied through the drip at a rate of $8 \mathrm{~kg}$ of $\mathrm{N}$ per hectare (14-0-1).

\subsubsection{Weed Populations}

After tarp removal, fields were drip irrigated for 6 hours per week for 6 weeks to stimulate weed germination. Measurements on weed biomass, density and relative species cover were taken on 12 October from 3 randomly selected locations in each bed using a $1 \times 1 \mathrm{~m}$ quadrat. Relative species cover was estimated based on the percent area each weed species covered. For weed biomass, all aboveground plant material in the 
quadrat was cut using shears at the base of the plant and placed in paper bags. Paper bags were placed in a drpying oven set at $70^{\circ} \mathrm{C}$ for 72 hours. Weeds were weighed upon removal from oven.

Remaining weed biomass and relative species cover measurements were taken in November and December from weedy checks on the edge of each plot $(1.33 \mathrm{~m} \times 1.33 \mathrm{~m})$. Weed biomass readings were taken using a $0.33 \mathrm{~m} \times 1 \mathrm{~m}$ quadrat and dry weight was measured. The relative species composition of the entire weedy check was recorded. Remaining weed density measurements were recorded in $30 \mathrm{~cm} \times 30 \mathrm{~cm}$ areas surrounding 16 randomly chosen strawberries per plot in November and December. Measurements were not taken in January as frosts killed many weeds affecting biomass and relative species cover measurements.

\subsubsection{Verticillium dahliae Inoculum Density}

Soil samples were taken using a $2.5 \mathrm{~cm}$ soil core from a depth of $0-15 \mathrm{~cm}$ in all plots before and after treatments to determine inoculum density of $V$. dahliae Kleb. Three random samples were taken per plot and mixed together to comprise one composite sample. Samples were air dried in open plastic bags at room temperature for 3 weeks.

After air drying, soil samples were ground up with a mortar and pestle for 5 minutes. For each composite sample, five randomly selected $0.1 \mathrm{~g}$ subsamples were analyzed, then they were mixed with $900 \mu \mathrm{L}$ of water and evenly spread onto Sorenson's NP-10 media (Kabir et al. 2007) prepared in petri dishes (100 mm x $15 \mathrm{~mm})$. Plates were incubated for 2 weeks at room temperature $\left(21^{\circ} \mathrm{C}\right)$ under dark conditions. After incubation, soil was gently rinsed off plates and $V$. dahliae colony forming units were counted under a dissecting microscope. 


\subsubsection{Disease Incidence in Strawberries}

Strawberries started to show signs of disease in early March 2019. After first signs of disease all plants were rated weekly on a scale of 0 to $5(0=$ no signs of disease, $1=$ leaf discoloration in $<20$ percent of leaves, mild stunting, $2=25-50 \%$ of leaves discolored or showing signs of disease, moderate stunting. $3=50-75 \%$ leaves dead or discolored, severe stunting, 4=75-95\% leaves dead or discolored, very severe stunting, almost dead, 5= dead) (Figure 3.1).

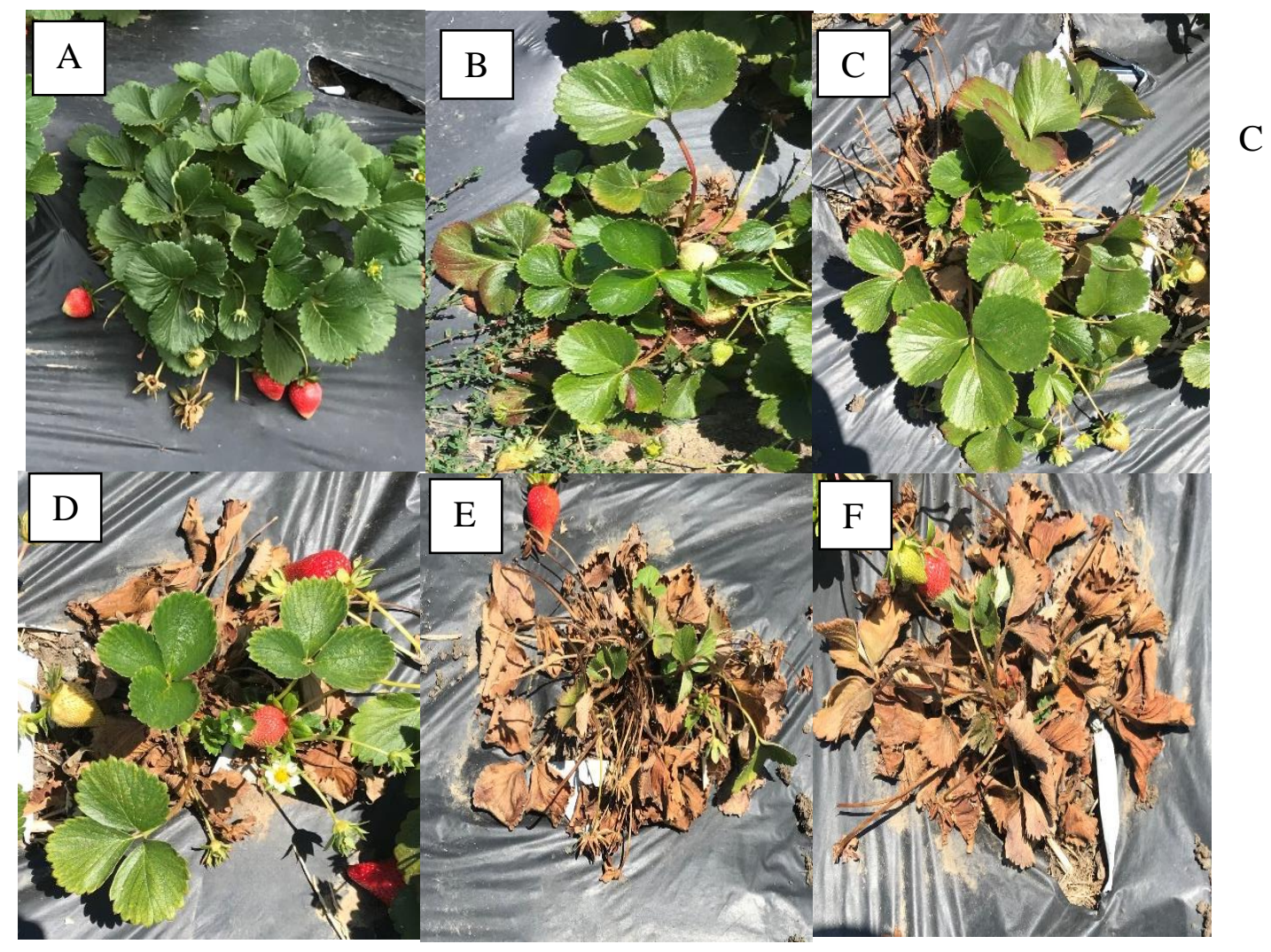

Figure 3.1: Examples of Strawberries Ranked from 0-5 on The Disease Severity Scale. $A=0, B=1, C=2$, $D=3, E=4, F=5$. 
Individual symptomatic plants were selected for disease assays to determine the causal agent. Plants chosen for pathogen analysis were washed under tap water and cut into roots, crown, and petioles. Plant were then surface sterilized in a $1 \%$ bleach solution for 60 seconds. Plant parts were removed from solution, rinsed with sterile water, then placed on sterile paper towels in a laminar flow hood. After drying, roots, crowns and petioles were placed on petri dishes containing potato dextrose agar (Sigma Aldrich, St. Louis, MO, USA) and Sorensen's Np 10 (Kabir et al. 2007). Plates were incubated under illuminated conditions at $25^{\circ} \mathrm{C}$. Plates were inspected after 3 to 7 days using a compound microscope. Additionally, plants were tested for Phytophthora spp. using Agdia immunostrips (Agdia Inc., Elkhart, IN, USA) following the manufacturer instructions.

\subsubsection{Strawberry Health and Yields}

Canopy volume measurements (width $\times$ length $\times$ height) were taken every two weeks from 15 March to 30 June 2019 from five randomly selected plants per plot. Yields were taken twice a week from 15 March to 30 June 2019. Rotted and misshapen fruit were picked and discarded as they comprised a small percentage (2-3\%) of fruit. Picked fruit were divided into three categories: marketable, vertebrate damage, and small fruit $(<10 \mathrm{~g})$. Weight and number of fruit were recorded for each category.

Degrees brix was measured from marketable fruit during April and May. Early yields in March and late yields in June did not produce enough fruit across all plots to support ${ }^{\circ}$ Brix data. ${ }^{\circ}$ Brix measurements were taken weekly and used five randomly chosen fruit from each plot. The middle of each fruit was squeezed until 2-3 drops collected on a refractometer. Two measurements were taken for each fruit and averaged. 


\subsubsection{Statistical Analysis}

Data were analyzed using SAS University Edition 9.4 (SAS Institute, Cary, NC, USA) using a standard split plot analysis. Sudangrass treatments, solarization treatments, block, and interaction between sudangrass and solarization treatments were incorporated into a PROCGLM model. A separate error term (sudangrass treatment*block) was used to analyze sudangrass data. If multiple measurements were taken per plot, measurements were averaged leading to a single value for each plot. A significance level of 0.05 was used for all data. For pairwise comparisons a protected Fisher's LSD was used. 


\subsection{Results}

\subsubsection{Sudangrass Growth}

Sudangrass grew to an average height of $1.52 \mathrm{~m}$ and accumulated an average biomass of 9,802 kg per hectare. Sudangrass regrew in mulched, non-solarized treatments, growing to a height of 1.5 meters before mowing and subsequent application of black plastic on beds. After application of black plastic, sudangrass continued to grow in mulched treatments until December when it winter killed. Mulched, non-solarized treatments required weeding of sudangrass regrowth to allow for strawberry establishment.

\subsubsection{Soil Temperatures}

Maximum soil temperatures achieved in solarized treatments were $53^{\circ} \mathrm{C}$ at a soil depth of $5 \mathrm{~cm}$ and $43^{\circ} \mathrm{C}$ at a soil depth of $15 \mathrm{~cm}$ (Table 3.2). Average daily maximum temperatures were $2.5^{\circ} \mathrm{C}$ higher in incorporated, solarized and no sudangrass, solarized treatments than in solarized, mulched treatments. All solarized treatments resulted in temperatures at least $10^{\circ} \mathrm{C}$ higher than non-solarized treatments. At $5 \mathrm{~cm}$ solarized treatments resulted in 135 to 188 cumulative hours above $40^{\circ} \mathrm{C}$ and 0 to 51 hours above $45^{\circ} \mathrm{C}$. At $15 \mathrm{~cm}$, solarized treatments resulted in 0 to 33 cumulative hours above $40^{\circ} \mathrm{C}$. 
Table 3.2: Average Maximum Temperatures, Maximum Temperature Achieved (Not Averaged), and Average Number of Hours Where Temperature Was Above $40^{\circ} \mathrm{C}$ and $45^{\circ} \mathrm{C}$ at a Depth of $5 \mathrm{~cm}$ And $15 \mathrm{~cm}$. Data recorded in all solarized treatments $(n=3)$ and in control treatments $(n=4)$.

\begin{tabular}{|c|c|c|c|c|c|c|c|c|}
\hline Treatment & $\begin{array}{c}\text { Average } \\
\text { max } \\
\text { temperature } \\
\left({ }^{\circ} \mathrm{C}\right) 5 \mathrm{~cm}\end{array}$ & $\begin{array}{c}\text { Average } \\
\text { max } \\
\text { temperature } \\
\left({ }^{\circ} \mathrm{C}\right) 15 \mathrm{~cm}\end{array}$ & $\begin{array}{c}\text { Max } \\
\text { temperature } \\
\left({ }^{\circ} \mathrm{C}\right) 5 \mathrm{~cm}\end{array}$ & $\begin{array}{c}\text { Max } \\
\text { temperature } \\
\left({ }^{\circ} \mathrm{C}\right) 15 \mathrm{~cm}\end{array}$ & $\begin{array}{l}\text { Hours } \\
>40^{\circ} \mathrm{C} \\
5 \mathrm{~cm}\end{array}$ & $\begin{array}{l}\text { Hours } \\
>40^{\circ} \mathrm{C} \\
15 \mathrm{~cm}\end{array}$ & $\begin{array}{c}\text { Hours } \\
>45^{\circ} \mathrm{C} \\
5 \mathrm{~cm}\end{array}$ & $\begin{array}{l}\text { Hours } \\
>45^{\circ} \mathrm{C} \\
15 \mathrm{~cm} \\
\end{array}$ \\
\hline Mulched, solarized & $40.9 \pm 1.22$ & $34.9 \pm 1.04$ & 46.0 & 39.0 & 135 & 0 & 0 & 0 \\
\hline Incorporated, solarized & $42.6 \pm 1.26$ & $37.3 \pm 1.13$ & 53.0 & 41.5 & 189 & 24 & 32 & 0 \\
\hline No sudangrass, solarized & $43.2 \pm 1.30$ & $37.2 \pm 1.16$ & 49.0 & 43.0 & 188 & 33 & 51 & 0 \\
\hline No sudangrass, non-solarized & $30.3 \pm 0.92$ & $28.2 \pm 0.85$ & 35.5 & 32.0 & 0 & 0 & 0 & 0 \\
\hline
\end{tabular}




\subsubsection{Weed Populations}

\subsubsection{Weeds present}

Little mallow (Malva parviflora L.) and annual sowthistle (Sonchus oleracea L.) comprised most of the weed population. Other species present were nettleleaf goosefoot (Chenopodium murale L.), common purslane (Portulaca oleracea L.) bristly oxtongue (Picris echioides L.), sharppoint fluvellin (Kickxia elatine L.), curly dock (Rumex cripus L.), black nightshade (Solanum nigrum L.), and purple crabgrass (Digitaria sanguinalis L.).

\subsubsection{Weed Biomass}

Solarized treatments had significantly lower weed biomass and weed density than non-solarized treatments at 1.5 months and 2.5 months after solarization (Table 3.3). In the December reading (3.5 months after tarp removal) weed biomass was lower in solarized than non-solarized treatments, but weed density was similar between those two treatments (Table 3.3). The difference in weed biomass between solarized and nonsolarized treatments decreased from one reading to the next. Solarized treatments reduced weed biomass over non-solarized treatments by $95.2 \%$ in October, $90.0 \%$ in November, and $49.8 \%$ in December.

Sudangrass treatments did not have a significant effect on weed populations until December. However, throughout the experiment mulched treatments tended to have lower weed biomass than no sudangrass and incorporated treatments. In October and November mulched treatments reduced weed biomass by $81.2 \%$ to $93.2 \%$ over incorporated and no sudangrass treatments. In December, mulched treatments had significantly lower weed biomass than incorporated treatments although similar weed 
biomass levels to no sudangrass treatments (Table 3.3). Although not significantly different, mulched treatments reduced weed density by 77.4 and $79.5 \%$ compared to other sudangrass treatments in December.

Table 3.3: Weed Biomass $\left(\mathrm{g} / \mathrm{m}^{2}\right)$ and Weed Density (Number/M²) Measurements Taken 1.5 Months (Oct.), 2.5 Months (Nov.), and 3.5 Months (Dec.) After Tarp Removal. Sudangrass ( $n=8,7$ for sudangrass mulch), solarization ( $n=12,11$ for non-solarized) and sudangrass* ${ }^{*}$ solarization interaction effects determined using a split-plot ANOVA. Pairwise comparisons were generated using protected Fisher's $L S D(p \leq 0.05$.) Within a factor, values sharing the same letter are not significantly different.

\begin{tabular}{ccccccc}
\hline & \multicolumn{5}{c}{ Weed measuremnts (Oct-Dec) } \\
\hline Treament & $\begin{array}{c}\text { Biomass } \\
\text { Oct } \\
\left(\mathrm{g} / \mathrm{m}^{2}\right)\end{array}$ & $\begin{array}{c}\text { Density } \\
\text { Oct } \\
\left(\text { number } / \mathrm{m}^{2}\right)\end{array}$ & $\begin{array}{c}\text { Biomass } \\
\text { Nov } \\
\left(\mathrm{g} / \mathrm{m}^{2}\right)\end{array}$ & $\begin{array}{c}\text { Density } \\
\text { Nov } \\
\left(\text { number } / \mathrm{m}^{2}\right)\end{array}$ & $\begin{array}{c}\text { Biomass } \\
\text { Dec } \\
\left(\mathrm{g} / \mathrm{m}^{2}\right)\end{array}$ & $\begin{array}{c}\text { Density } \\
\text { Dec } \\
(\text { number/m })^{2}\end{array}$ \\
\hline Sudangrass effect $P r>F$ & 0.06 & 0.33 & 0.31 & 0.17 & 0.03 & 0.08 \\
Mulched & 2.02 & 9.14 & 18.3 & 3.61 & $74.3 \mathrm{~b}$ & 7.92 \\
Incoporated & 22.5 & 8.08 & 116 & 11.9 & $192 \mathrm{a}$ & 35.3 \\
No Sudangrass & 29.5 & 17.0 & 93.0 & 16.3 & $135 \mathrm{ab}$ & 38.6 \\
\hline Solarization effect $P r>F$ & $<0.01$ & 0.01 & 0.02 & 0.04 & 0.02 & 0.10 \\
Non-solarized & $34.4 \mathrm{a}$ & $17.2 \mathrm{a}$ & $138 \mathrm{a}$ & $16.6 \mathrm{a}$ & $178 \mathrm{a}$ & 34.5 \\
Solarized & $1.67 \mathrm{~b}$ & $5.30 \mathrm{~b}$ & $13.8 \mathrm{~b}$ & $4.72 \mathrm{~b}$ & $89.6 \mathrm{~b}$ & 20.02 \\
\hline Sudangrass*solarization & 0.06 & 0.22 & 0.09 & 0.29 & 0.01 & 0.25 \\
effect $P r>F$ & & & & &
\end{tabular}

A solarization $\times$ sudangrass treatment interaction was observed in weed biomass measurements taken in December (Figure 3.2). Sudangrass treatments reacted differently depending on whether or not they were solarized. In non-solarized plots, mulched treatments had significantly lower weed biomass than no sudangrass treatments $(p=0.045)$ and incorporated treatments $(p=0.0008)$. Incorporated, non-solarized treatments had the highest levels of weed biomass recorded out of all non-solarized treatments. In solarized plots, incorporated and no sudangrass treatments had similar weed biomass to mulched treatments. 


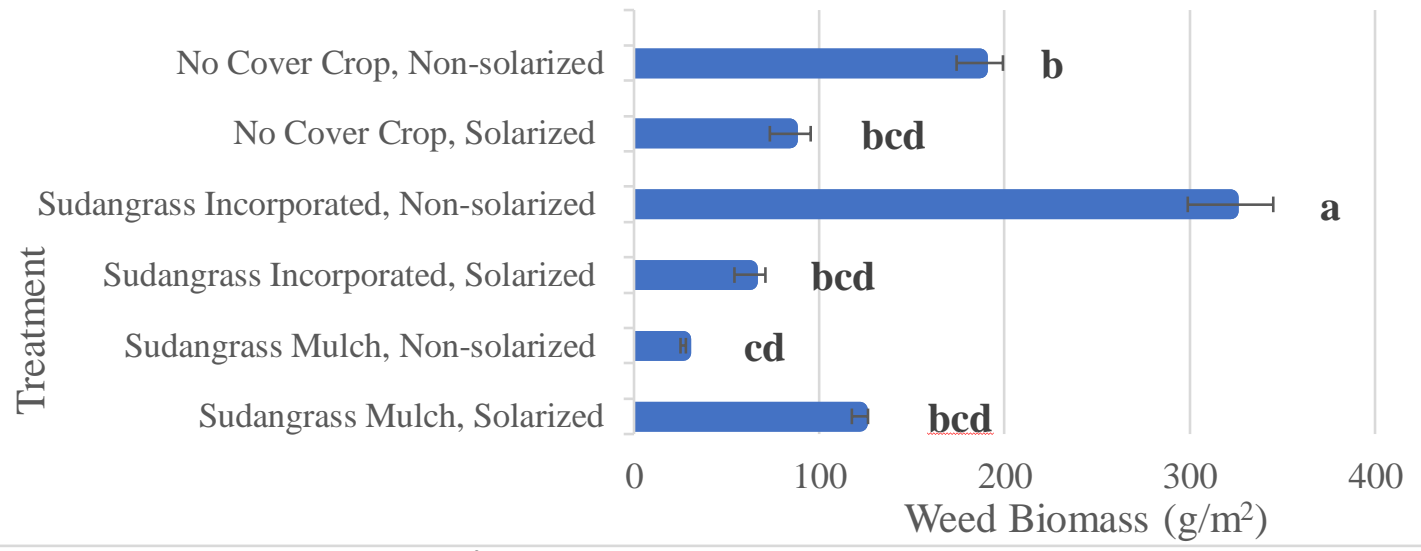

Figure 3.2: Weed Biomass $\left(\mathrm{g} / \mathrm{m}^{2}\right)$ of Each Interaction Treatment Between Sudangrass and Solarization Taken in December ( $p=.01, n=4,3$ for sudangrass mulch, solarized). Pairwise comparisons were generated using protected fishers $L S D(p \leq 0.05)$. Values sharing the same letter are not significantly different.

\subsubsection{Relative Species Cover}

At 1.5 and 2.5 months after tarp removal little mallow and annual sowthistle comprised significantly lower percent ground cover in solarized than in non-solarized treatments (Table 3.4). At 3.5 months after tarp removal, percent ground cover for little mallow and annual sowthistle was not statistically different in solarized vs. non solarized treatments (Table 3.4). Furthermore, little mallow species cover was $133 \%$ higher in solarized treatments than in non-solarized treatments, whereas annual sowthistle cover was reduced by $65.4 \%$ in solarized treatments. Common purslane cover was $242 \%$ higher in solarized treatments than in non-solarized treatments six weeks after solarization. Common purslane germinated under solarization tarps in some treatments. However, common purslane populations decreased in November as the weather cooled off. Total weed cover was significantly reduced in solarized treatments compared to non-solarized treatments in October and November (Table 3.4). In December, solarized and nonsolarized treatments contained similar total weed cover. 
Table 3.4: Relative Ground Cover of Prominent Weed Species in Weedy Checks 1.5 Months After Tarp Removal (13 Oct), 2.5 Months After Tarp Removal (9 Nov) and 3.5 Months After Tarp Removal (12 Dec) Between Solarized and Non-Solarized Treatments ( $n=12$, 11 for solarized treatments). Pr $>f$ values of less than of 0.05 indicate significant differences between solarized and non-solarized treatments using a Fishers protected LSD.

\begin{tabular}{cccccccccc}
\hline \multicolumn{10}{c}{ Weed ground cover (\%) } \\
\hline \multicolumn{10}{c}{ 13-Oct } \\
\hline Species & $\begin{array}{c}\text { Non- } \\
\text { solarized Solarized }\end{array}$ & $\operatorname{Pr}>F$ & $\begin{array}{c}\text { Non- } \\
\text { solarized }\end{array}$ & Solarized & $\operatorname{Pr}>F$ & $\begin{array}{c}\text { Non- } \\
\text { solarized }\end{array}$ & Solarized & $\operatorname{Pr}>F$ \\
\hline Little mallow & 11.9 & 1.73 & $<0.01$ & 35.5 & 9.83 & $<0.01$ & 30.8 & 41.4 & 0.46 \\
Annual sowthistle & 12.8 & 0.03 & 0.04 & 21.9 & 1.00 & 0.02 & 34.2 & 11.8 & 0.10 \\
Common purslane & 0.96 & 2.32 & 0.33 & 0.83 & 1.00 & 0.95 & 0.00 & 0.00 & n/a \\
\hline Total & 26.9 & 4.50 & $<0.01$ & 58.3 & 23.8 & $<0.01$ & 65.83 & 58.72 & 0.57 \\
\hline
\end{tabular}

Sudangrass treatments did not have a significant impact on relative species cover except for the total weed cover in October $(p=0.009)$ and annual sowthistle populations in November $(p=0.048)$, where mulched treatments had lower weed cover than no sudangrass or incorporated treatments. There was an interaction between sudangrass treatments and total weed cover during October, November, and December (Table 3.5). For non-solarized plots, total weed species cover was lower in mulched treatments than incorporated or no sudangrass treatments. In solarized plots, mulched treatments tended to have higher total weed cover than incorporated or no sudangrass treatments.

Table 3.5: Interaction Effect of Sudangrass and Solarization Treatments of Total Weed Cover (\%) in Weedy Checks Taken 1.5 Months, 2.5 Months, and 3.5 Months After Tarp Removal (n=4, 3 for sudangrass mulch, non-solarized). Within each column, pairwise comparisons were generated using protected Fisher's LSD test at $p \leq 0.05$. Values sharing same letter are not significantly different.

\begin{tabular}{cccc}
\hline & \multicolumn{3}{c}{ Total weed cover $(\%)$} \\
\cline { 2 - 4 } Treatment & Oct & Nov & Dec \\
\hline Mulched, solarized & $5.33 \mathrm{~b}$ & $58.3 \mathrm{a}$ & $80.0 \mathrm{ab}$ \\
Mulched, non-solarized & $7.21 \mathrm{~b}$ & $6.25 \mathrm{~b}$ & $15.0 \mathrm{c}$ \\
Incorporated, solarized & $4.30 \mathrm{~b}$ & $3.78 \mathrm{~b}$ & $48.8 \mathrm{bc}$ \\
Incorporated, non-solarized & $33.7 \mathrm{a}$ & $90.0 \mathrm{a}$ & $88.8 \mathrm{ab}$ \\
No sudangrass, solarized & $4.08 \mathrm{~b}$ & $9.28 \mathrm{~b}$ & $52.8 \mathrm{abc}$ \\
No sudangrass, non-solarized & $39.7 \mathrm{a}$ & $78.0 \mathrm{a}$ & $93.8 \mathrm{a}$ \\
Sudangrass*solarization $\operatorname{Pr}>F$ & $<0.01$ & $<0.01$ & 0.01 \\
\hline
\end{tabular}




\subsubsection{Verticillium dahliae Populations}

Before soil solarization, $V$. dahliae populations were significantly lower in solarized treatments compared to non-solarized treatments (Figure 3.3). After solarization treatments were conducted the difference became more pronounced. The largest difference between solarized and non-solarized treatments occurred in September, immediately after solarization. Post solarization, $V$. dahliae populations ranged from 1.5 to $5.1 \mathrm{CFU} / \mathrm{g}$ in solarized treatments and 7.6 to $30.7 \mathrm{CFU} / \mathrm{g}$ in non-solarized treatments. There were significantly lower populations of $V$. dahliae in September, November and June in solarized treatments compared to non-solarized treatments. In January, no differences were observed between solarized and non-solarized treatments, although $V$. dahliae populations in solarized treatments were $61.6 \%$ lower than non-solarized treatments.

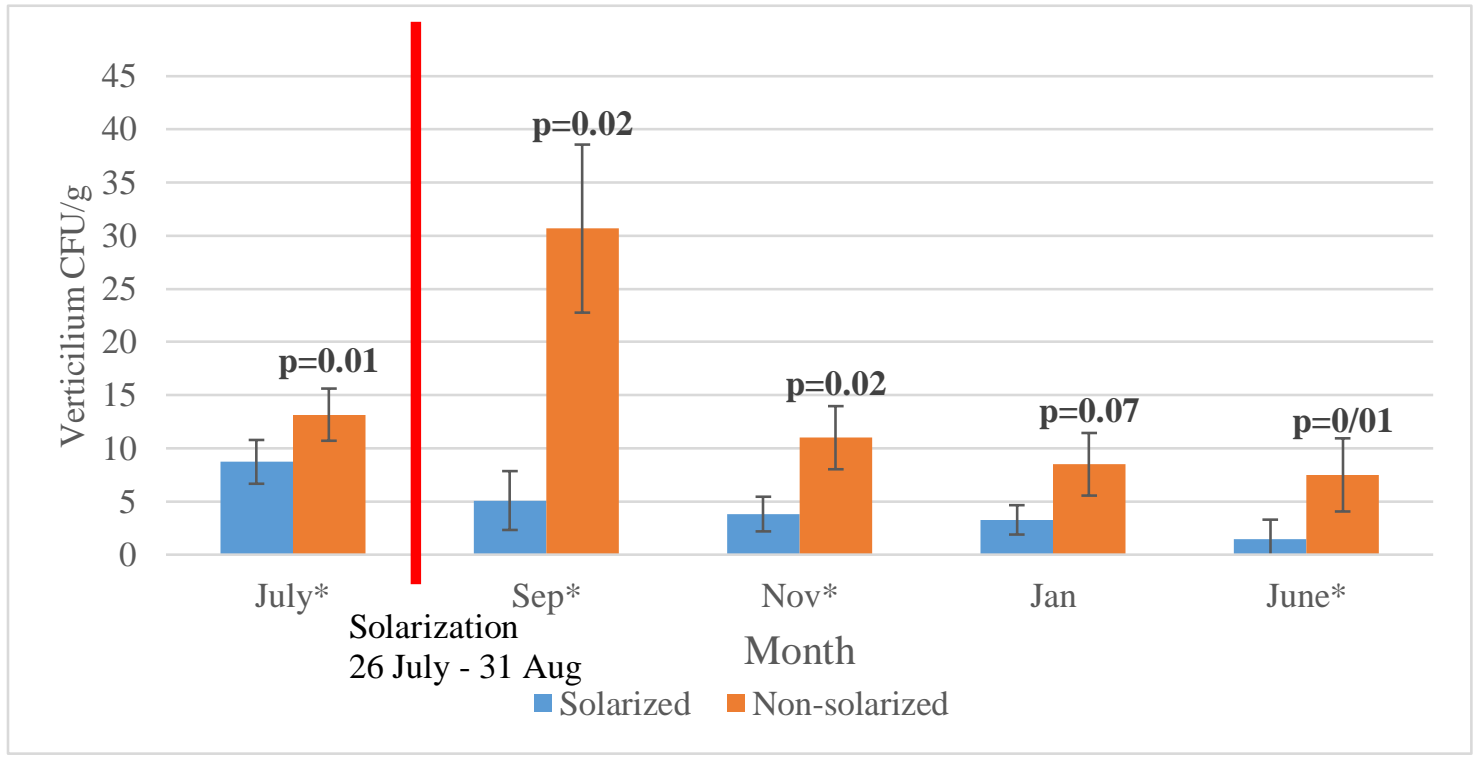

Figure 3.3: Verticillium dahliae Populations (Colony Forming Units (CFU)/g) in Solarized Vs NonSolarized Treatments Taken from July 2018 (Pre-Solarization Treatments) to June 2019 (End of Harvest) ( $n=12,11$ for solarized treatments). $P$-value derived from a split plot ANOVA. *Denotes a significant difference between solarized and non-solarized treatments using a protected Fisher's LSD test $(p \leq .05)$ 
Sudangrass treatments had no significant effects on $V$. dahliae populations

(Figure 3.4). However, some trends were observed in sudangrass treatments. In mulched treatments, a large jump in $V$. dahliae populations occurred in September, while the sudangrass was still actively growing. Levels decreased to pre-solarization levels in November after sudangrass was mowed twice and tarped. There were no significant interactions between sudangrass treatments and solarization treatments.

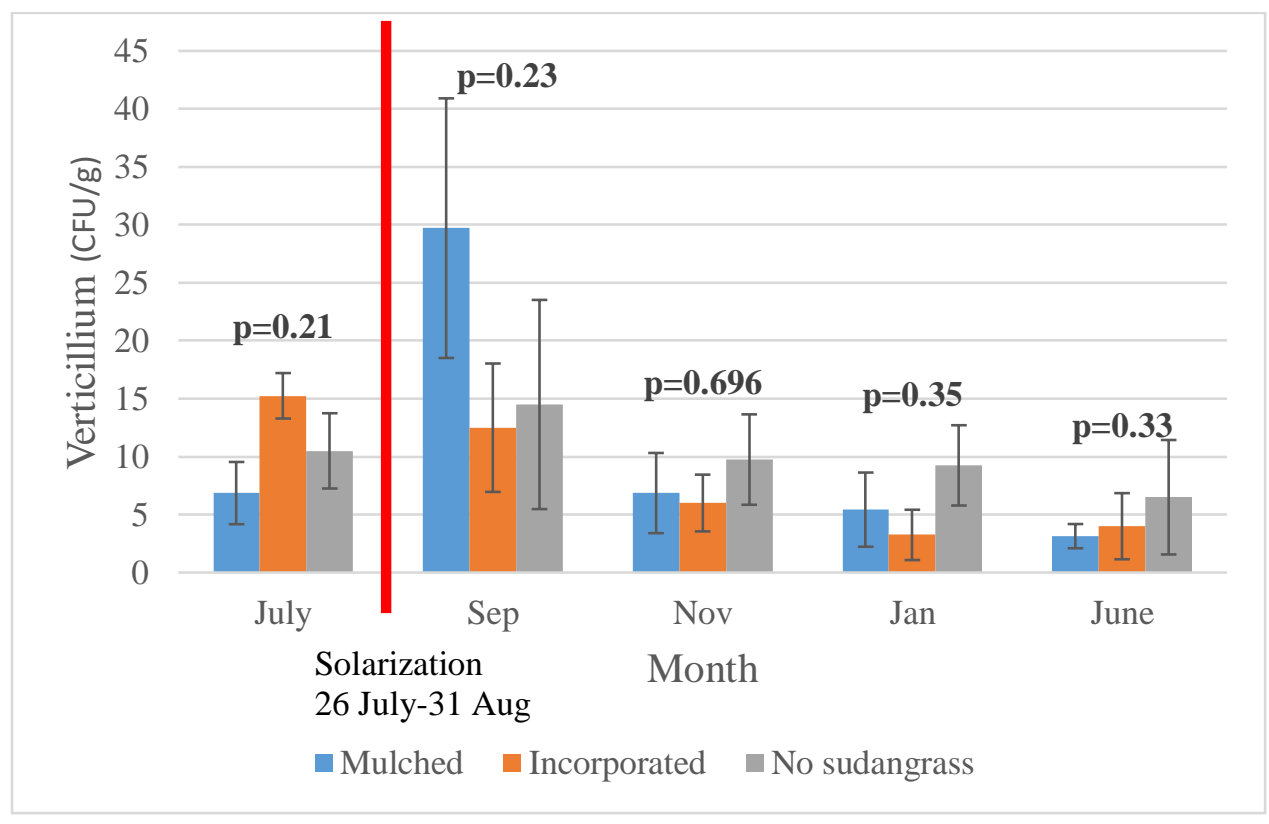

Figure 3.4: Verticillium dahliae Populations (Colony Forming Units (CFU)/g) in Sudangrass Treatments Taken from July 2018 (Pre-Solarization Treatments) to June 2019 (End of Harvest) $(n=8,7$ for mulched treatments). P-value derived from a split plot ANOVA. No significant values were observed $(p \leq 0.05)$. 


\subsubsection{Canopy Volume}

Canopy volume was used to determine the overall health of plants during the growing season. Canopy volume increased rapidly in March and early April, peaking in May during peak production season, and decreasing again in June as late-season disease stunted plants. The decrease in late season canopy volume can also be partially attributed to heat stress. Both solarization and sudangrass treatments influenced canopy volume. From 29 March until 24 June solarized treatments contained significantly higher canopy volume than non-solarized treatments (Figure 3.5). Solarized treatments' canopy volume peaked at $18,412.63 \mathrm{~cm}^{3}$ on 15 May, while non-solarized treatments' canopy volume peaked on 31 May at $10,226 \mathrm{~cm}^{3}$.

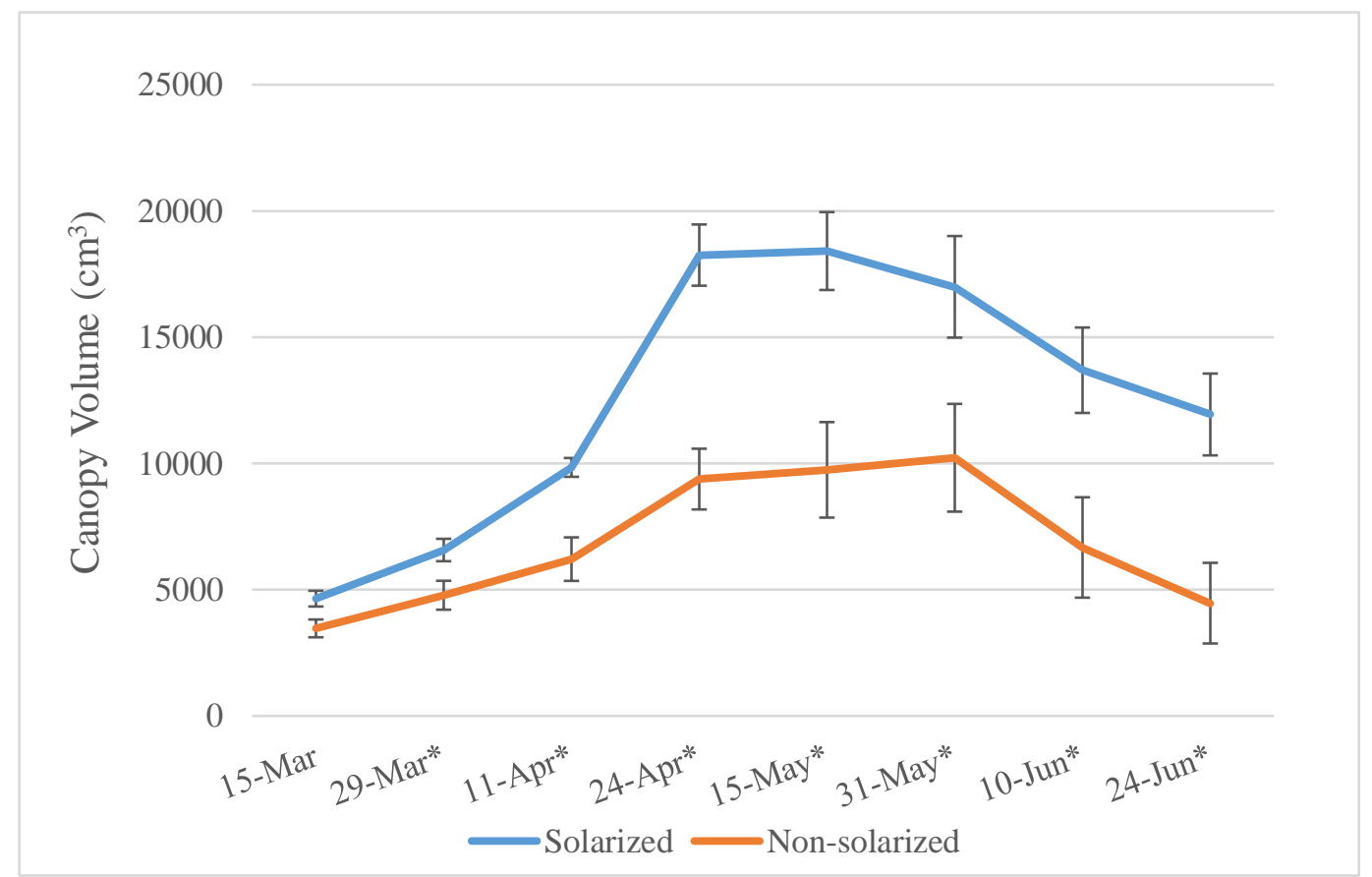

Figure 3.5: Average Canopy Volume $\left(\mathrm{cm}^{3}\right)$ Measurements Taken from Five Random Plants per Plot Every Two Weeks During Strawberry Harvest (15 March To 30 June) in Solarized vs Non-Solarized Treatments $(n=12,11$ for solarized treatments). *Denotes a significant difference between solarized and non-solarized treatments using a protected Fisher's LSD test ( $p \leq 05)$. 
The effect of the sudangrass factor was not significant until June (Figure 3.6). On 10 and 24 June, mulched treatments had significantly higher canopy volumes than the no sudangrass and incorporated treatments. Incorporated treatments tended to have a higher canopy volume than no sudangrass treatments. All sudangrass treatments saw decreases in canopy volume beginning in June correlating with disease severity. Canopy volume in the incorporated and no sudangrass treatments maxed out on 24 April at 15,036 and $14,600 \mathrm{~cm}^{3}$. In the mulched treatments, the highest canopy volume occurred on 15 May at $19,097 \mathrm{~cm}^{3}$.

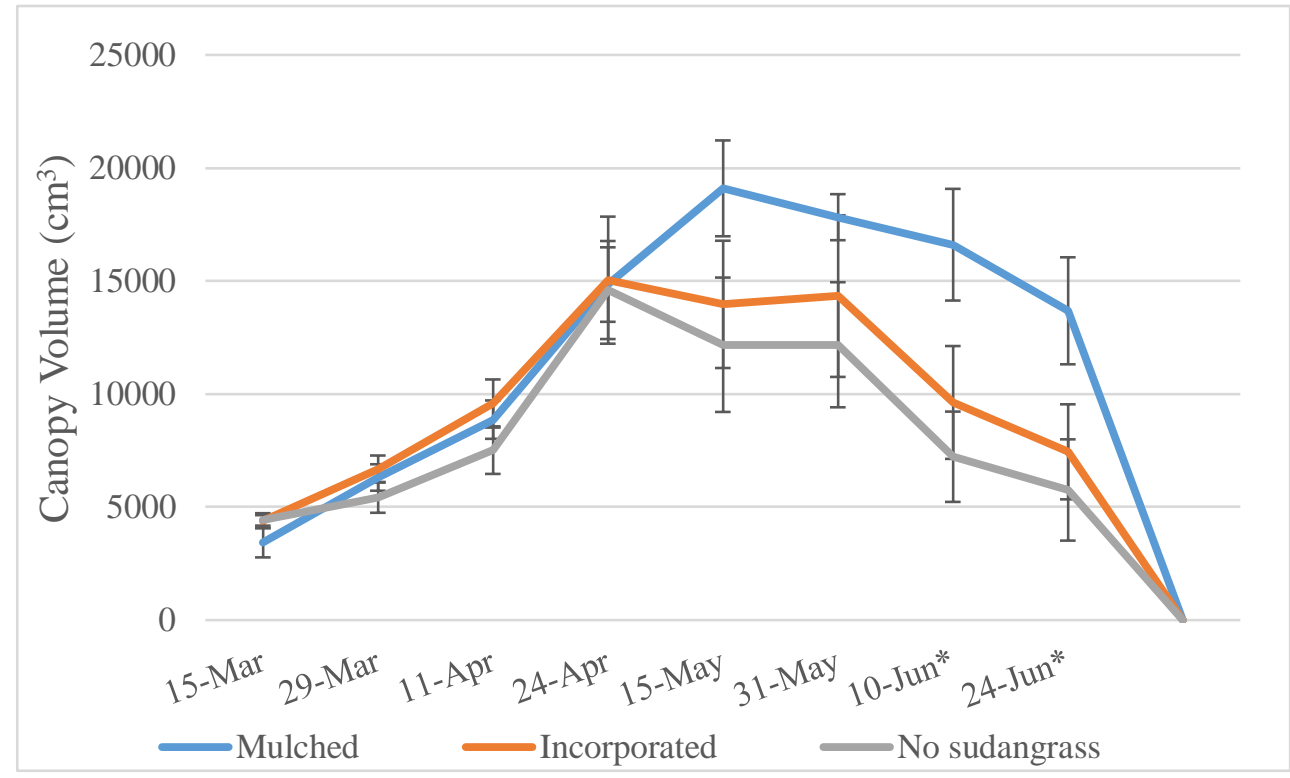

Figure 3.6: Average Canopy Nolume $\left(\mathrm{cm}^{3}\right)$ Measurements Taken from Five Random Plants per Plot Every Two Weeks During Strawberry Harvest (15 March to 30 June) in Sudangrass Treatments: mulched, incorporated, and no sudangrass ( $n=8,7$ for mulched treatments). *Denotes a significant difference between solarized and non-solarized treatments using a protected Fisher's LSD test ( $p \leq 0.05$ ).

\subsubsection{Disease Incidence}

Both sudangrass and solarization factors had significant effects on disease severity (Figures 3.7 and 3.8). There were no interactions between the two factors. $V$. dahliae and M. phaseolina were isolated from diseased plants in high enough numbers to 
be determined as the causal agents of disease. M. phaseolina tended to occur more frequently in solarized plots ( $73.3 \%$ of isolations were in solarized plots) and $V$. dahliae occurred more frequently in non-solarized plots (67.8 of isolations were in non-solarized plots). However, not enough diseased plants were successfully identified to draw conclusions about effects of solarization and sudangrass residues on disease incidence of different pathogens.

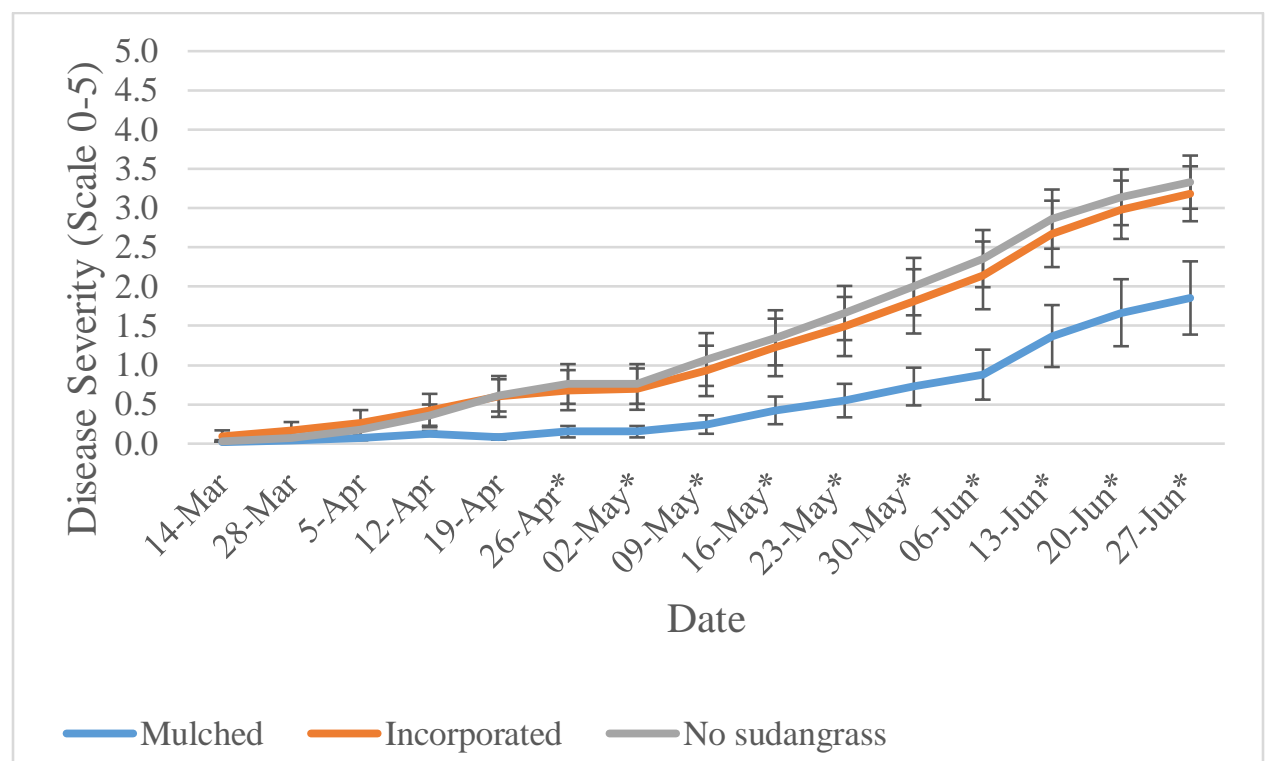

Figure 3.7: Disease Severity on a Scale of 0 (No Disease) to 5 (Dead) of Sudangrass Treatments $(n=8,7$ for mulched treatments). *Denotes a significant difference between solarized and non-solarized treatments using a protected Fisher's LSD test ( $p \leq 0.05)$. 


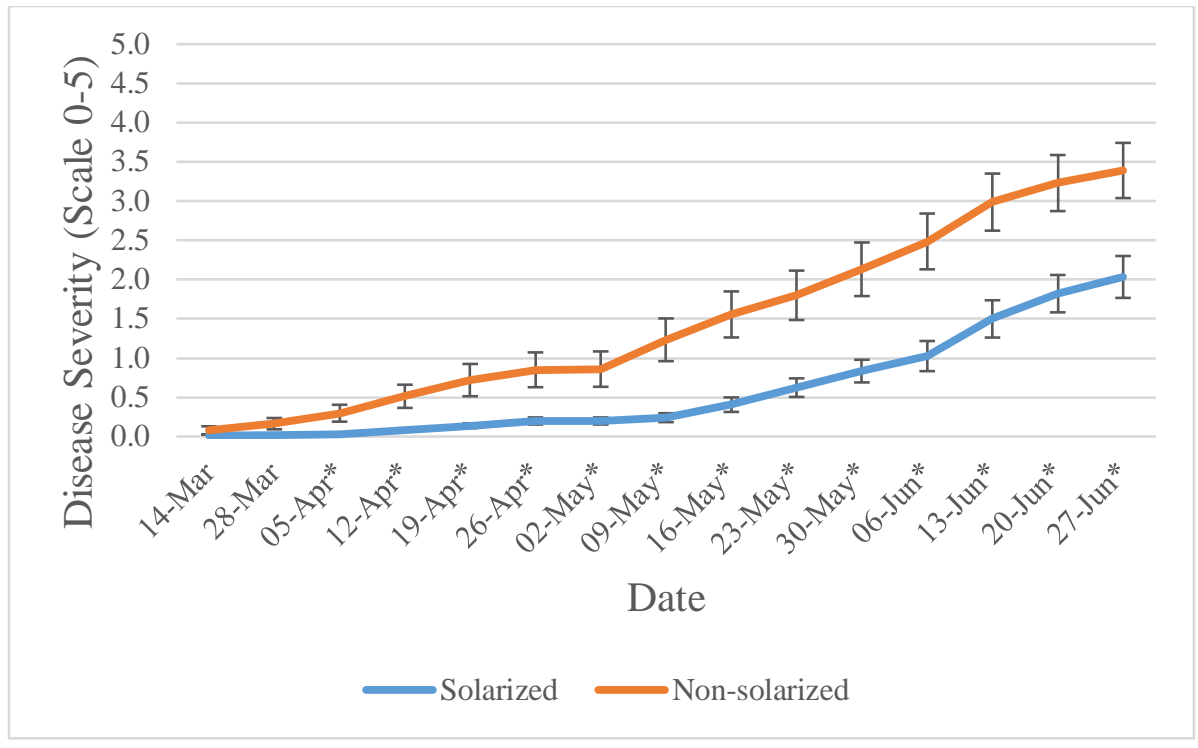

Figure 3.8: Disease Severity on a Scale of 0 (No Disease) to 5 (Dead) in Solarized vs Non-Solarized Treatments $(n=12,11$ for Solarized Treatments). *Denotes a significant difference between solarized and non-solarized treatments using a protected Fisher's LSD test ( $p \leq 0.05)$.

Solarization and sudangrass treatments both had strong effects on disease severity. Starting on 5 April until the end of the experiment, solarized treatment had significantly lower disease severity than non-solarized treatments. Mulched treatments had lower disease severity than both incorporated and no sudangrass treatments starting on 26 April till the termination of the experiment. No interaction effects were observed for disease severity.

At the end of the experiment, solarized treatments had significantly lower disease incidence than non-solarized treatments (Table 3.6). Sudangrass treatments had no significant effect on disease incidence, however, mulched treatments tended to have lower disease incidence than incorporated and no sudangrass treatments. No interaction effects were observed for disease incidence. Plant mortality was significantly lower in solarized than non-solarized treatments (Table 3.6). Solarized treatments reduced plants mortality by $54.9 \%$ over non-solarized treatments. mulched treatments had significantly lower plant mortality than both incorporated and no sudangrass treatments (Table 3.6), 
reducing plant mortality from $64.9 \%$ to $66.2 \%$ over sudangrass incorporated and no sudangrass treatments.

Table 3.6: Disease Incidence (\% of Total Infected Plants) and Plant Mortality (\% of Dead Plants) Measurements Recorded at the End of Harvest (June $28^{\text {th }}$ ) for Sudangrass and Solarization Treatments. Sudangrass ( $n=8,7$ for mulched), solarization ( $n=12,11$ for non-solarized) and sudangrass ${ }^{*}$ solarization interaction effects determined using a split-plot ANOVA. Pairwise comparisons generated using protected Fisher's LSD at $p \leq 0.05$. Within a factor, values sharing the same letter are not significantly different.

\begin{tabular}{lcc}
\hline & $\begin{array}{c}\text { Disease } \\
\text { incidence (\%) }\end{array}$ & Plant mortality (\%) \\
\hline Sudangrass effect Pr $>F$ & 0.07 & $<0.01$ \\
Mulched & 66.3 & $11.3 \mathrm{a}$ \\
Incorporated & 92.2 & $33.3 \mathrm{~b}$ \\
No Sudangrass & 94.3 & $32.1 \mathrm{~b}$ \\
\hline Solarization effect Pr $>F$ & $<0.01$ & $<0.01$ \\
Solarized & $77.9 \mathrm{a}$ & $16.0 \mathrm{a}$ \\
Non-solarized & $91.5 \mathrm{~b}$ & $35.5 \mathrm{~b}$ \\
\hline Sudangrass*solarization effect $P r>F$ & 0.3879 & 0.2273 \\
\hline
\end{tabular}

\subsubsection{Yields}

Solarized treatments generated roughly triple the yield of non-solarized

treatments. Solarized treatments also had a significantly higher average fruit weight than non-solarized treatments (Table 3.7). However, the ${ }^{\circ}$ brix of strawberries in solarized treatments was significantly lower than non-solarized treatments as smaller fruit tended to be sweeter than larger fruit. Sudangrass management techniques did not have a significant effect on marketable yield. However, yield tended to decrease in the order: mulched $>$ incorporated $>$ no sudangrass. Mulched treatments did have a significantly higher average fruit weight than incorporated or no sudangrass treatments. However, fruit in mulched treatments had significantly lower ${ }^{\circ}$ brix than no sudangrass treatments. There were no interaction effects for marketable yield, ${ }^{\circ}$ brix, and average weight. 
Table 3.7: Marketable Yield per 30 Plants (g), ${ }^{\circ}$ Brix (\% Sugar Content), and Average Weight of Marketable Fruit for Sudangrass and Solarization Treatments. Sudangrass ( $n=8,7$ for sudangrass mulch), solarization, ( $n=12,11$ for non-solarized) and sudangrass*solarization interaction effects determined using a split-plot ANOVA. Pairwise comparisons were generated using protected Fisher's LSD at $p \leq 0.05$. Within a factor, values sharing the same letter are not significantly different.

\begin{tabular}{lccc}
\hline & $\begin{array}{c}\text { Marketable yield } \\
\text { per } 30 \text { plant }(\mathrm{kg})\end{array}$ & $\begin{array}{c}{ }^{\circ} \text { Brix } \\
\text { (\% sugar content) }\end{array}$ & $\begin{array}{c}\text { Average } \\
\text { weight }(\mathrm{g})\end{array}$ \\
\hline Sudangrass effect $\operatorname{Pr}>\mathrm{F}$ & 0.25 & $<0.01$ & 0.02 \\
Mulched & $8.81 \mathrm{a}$ & $9.03 \mathrm{a}$ & $30.7 \mathrm{~b}$ \\
Incorporated & $7.50 \mathrm{a}$ & $9.76 \mathrm{ab}$ & $25.1 \mathrm{a}$ \\
No sudangrass & $6.48 \mathrm{a}$ & $10.4 \mathrm{~b}$ & $25.3 \mathrm{a}$ \\
\hline Solarization effect $\operatorname{Pr}>\mathrm{F}$ & $<0.01$ & 0.01 & $<0.01$ \\
Solarized & $11.6 \mathrm{~b}$ & $9.1 \mathrm{a}$ & $29.7 \mathrm{~b}$ \\
Non-solarized & $3.84 \mathrm{a}$ & $10.4 \mathrm{~b}$ & $24 . \mathrm{a}$ \\
\hline Sudangrass*solarization & & & \\
effect $P r>F$ & 0.9781 & 0.0778 & 0.607
\end{tabular}

Large amounts of vertebrate pest damage occurred in the field (16.8\% of total yield). Damage was similar across all treatments. Fruit with vertebrate pest damage were excluded from marketable yield. Small fruit of less than 10 grams were also excluded from marketable yield and was not included in average weight. Small fruit comprised $4.3 \%$ of the total yield (total yield $=$ marketable yield + vertebrate pest damaged yield + small fruit) of mulched treatments, $10.7 \%$ of the total yield of incorporated treatments, and $12.3 \%$ of the total yield of no sudangrass treatments. Small fruit comprised $4.2 \%$ of the total yield for solarized treatments and $14.0 \%$ of the yield for non-solarized treatments. 


\subsection{Discussion}

Soil temperatures at a $5 \mathrm{~cm}$ depth were slightly different than those reached in other solarization experiments conducted along California's central coast. Temperatures were slightly lower $\left(2-3^{\circ} \mathrm{C}\right)$ in Salinas (Samtani et al. 2012) and were slightly higher (0-5 ${ }^{\circ} \mathrm{C}$ ) in southern California than temperatures observed during this study (Daugovish et al. 2016, Hartz et al. 1993). For comparison, solarization experiments conducted during August in California's central valley, which see frequent maximum air temperatures over $35^{\circ} \mathrm{C}$, have achieved average solarization temperatures of 5 to $8^{\circ} \mathrm{C}$ warmer than temperatures observed in this study at a $5 \mathrm{~cm}$ depth (Marshall et al. 2013). Previous solarization experiments in San Luis Obispo documented temperatures up to $77.5^{\circ} \mathrm{C}$ on the soil surface demonstrating the potential to achieve higher solarization temperatures in this area (Steinmaus and Walter 2003). However, it should be noted temperatures decrease rapidly as soil depths increase and in this study temperatures were not measured at the soil surface (Steinmaus and Walter 2002).

Soil solarization significantly reduced weed pressure particularly during the first 3.5 months after tarp removal. At 3.5 months after tarp removal weeds were germinating at similar rates in solarized and non-solarized treatments. By reducing weed pressure during the most critical period of strawberry growth, growers can reduce hand-weeding and/or herbicide costs. However, after this 3.5 month period other weed management techniques will be needed to control weeds in strawberries. In shorter season vegetable crops one solarization application could keep weeds below economic levels throughout the entire season. 
Other studies on coastal strawberry production also validate that solarization reduces weed populations, but will not keep weeds below economic levels throughout the entire growing season (Hartz et al. 1993, Samtani et al. 2012). Increasing length of solarization application or using repeated solarization application over multiple years may increase the efficacy of solarization. Additionally, other treatments such as soil steaming or soil fumigation with methyl bromide, for conventional growers, may reduce weed populations beyond that of solarization (Daugovish et al. 2016, Samtani et al. 2012).

Possible reasons for increase in weed germination 3.5 months after solarization treatments are release from secondary dormancy caused by solarization (Mauromicale et al. 2005) or movement of wind-blown seeds from weedy checks and edges of fields into plots. The increase of sowthistle populations from November to December in solarized treatments is likely due to seed being blown in from non-solarized treatments. Likewise, little mallow populations, which have been shown to be moderately resistant to solarization in some studies (Samtani et al. 2012, Stapleton et al. 2008a), likely increased in December as seeds overcame secondary dormancy induced by solarization. The germination of common purslane under tarps is not surprising given that purslane will germinate at temperatures up to $45^{\circ} \mathrm{C}$ (Dahlquist et al. 2007), which is above the observed average maximum temperature of this study at $43^{\circ} \mathrm{C}$.

In non-solarized plots, mulched treatments provided more effective weed control than other incorporated sudangrass or non-sudangrass treatments. This is consistent with results from experiments done with sudex in California's central valley (Stapleton et al. 2010). Incorporating sudangrass did not improve weed control over non-cover cropped 
treatments. In previous studies effects of incorporated sudangrass are variable, sometimes showing a suppressive effect (Stapleton et al. 2010), no effect (Nyczepir and RodriguezKabana 2007) or even stimulating weeds (Peachey et al. 2001). Differences could be a result of environmental conditions affecting the generation or breakdown of dhurrin, which hydrolyzes to hydrogen cyanide, and sorgoleone, an allelochemical exuded by the roots of most Sorghum spp. (Weston et al. 2013). Inconsistencies could also result from differences in the content of dhurrin and sorgoleone in different sorghum/sudangrass cultivars (De Nicola et al. 2011, Weston et al. 2013).

In non-solarized plots, mulched treatments tended to provide the most effective weed control while incorporated treatments provided the least effective weed control out of all three sudangrass treatments. Non-solarized, mulched treatments accumulated more cover crop biomass than other treatments, leading to more effective weed control. In solarized plots, mulched treatments tended to have the least effective weed control due to lower temperatures resulting from the gap between the tarp and the soil caused by the sudangrass mulch. For solarized plots, incorporated treatments tended to have the most effective weed control. Tarping incorporated plant residues has been shown to decrease weed populations over non-tarped plant residues (Earlywine et al. 2010). Tarping organic amendments prevents the escape and increases the concentration of biotoxic volatile products and organic acids generated when organic amendments decompose leading to increased efficacy over non-tarped plant residues (Gamliel and Stapleton 1993b, Simmons et al. 2016). However, given that mulched treatments were the least effective solarization treatment it appears heat has more effect on reducing weed populations than 
the accumulation of biotoxic volatile compounds and organic acids during biosolarization.

Despite its effective weed control, non-solarized, mulched treatments maintained active sudangrass growth until killed by frosts in December. This led to delayed growth of strawberry production in these treatments as they were competing with actively growing sudangrass. This was not an issue in solarized, mulched treatments as solarization killed sudangrass.

Reductions in $V$. dahliae caused by solarization are consistent with solarization treatments in southern California strawberry production (Hartz et al. 1993), but inconsistent with solarization treatments in northern California strawberry production where $V$. dahliae populations were not reduced (Samtani et al. 2011). Differences in treatments are likely due to differences in solar radiation between northern and southern California resulting in increased temperatures in southern California strawberry production.

Solarization combined with sudangrass residues reduced populations of $V$. dahliae in this study. However, sudangrass residues did not significantly increase control of $V$. dahliae in solarized treatments beyond that of no sudangrass, solarized treatments. Solarizing incorporated sudangrass residues has been shown to reduce $V$. dahliae populations in other locations (MacGuidwin et al. 2012, Pinkerton et al. 2000). However, solarized sudangrass treatments have not resulted in better pathogen or weed control than non-cover cropped, solarized treatments indicating no significant synergistic effect between incorporating cover crop and solarization (Davis et al. 2004, MacGuidwin et al. 2012, Peachey et al. 2001). 
Incorporating sudangrass residues has been shown to reduce inoculum densities and disease incidence of V. dahliae in a potato cropping system (Davis et al. 2004, MacGuidwin et al. 2012). This same effect was not observed in strawberry production as the inoculum density and disease incidence of Verticillium wilt in strawberries was similar between sudangrass and non-sudangrass treatments. One potential reason for this is the sensitivity of strawberries to Verticillium wilt (Bolda and Koike 2013). As little as 1-2 CFU/g of $V$. dahliae can cause 50\% disease incidence in strawberries (Harris and Yang 1996). Mulched treatments had lower disease severity and plant mortality than other sudangrass treatments. The most likely cause for this is lower initial pathogen loads in mulched treatments than other treatments. Alternatively, lower disease pressure in mulched treatments could result from healthier plants due to increased nutrient availability, reduced weed pressure, or an enhanced microbial community. Rotations of sudangrass cover crops with potato have increased populations of nonpathogenic Fusarium spp. which have been hypothesized to reduce root infection by V. dahliae (Davis et al. 2004). More research into solarizing mulched cover crops is necessary in order to determine its viability as a disease suppressing management technique.

Solarization provided significant reduction of disease severity, disease incidence, and plant mortality over non-solarized treatments. However, by the end of the harvest $77 \%$ of solarized strawberries showed some signs of disease, levels that may be unacceptable to growers. M. phaseolina was frequently isolated in plants from solarized treatments, but not from non-solarized treatments. Not enough diseased plants were used to give definitive numbers on the disease incidence caused M. phaseolina or V. dahliae. However, given the reduced populations of $V$. dahliae in solarized treatments and late 
onset of disease, it is likely that $M$. phaseolina, a late season pathogen adapted to warm conditions, caused most of the disease in solarized treatments. $M$. phaseolina has been found to be more resistant to solarization than $V$. dahliae, occasionally increasing in populations at temperatures where $V$. dahliae populations were reduced to almost zero (Kanaan et al. 2015). Lab experiments found that at $45^{\circ} \mathrm{C}$ a substantial reduction of $M$. phaseolina microsclerotia did not occur until 19 days of constant exposure (Yildiz et al. 2010). Given the cumulative hours above $45^{\circ} \mathrm{C}$ in this experiment, which range from 0 51 hours at $5 \mathrm{~cm}$ depending on treatment, it is likely that $M$. phaseolina was unaffected in this study. Other studies in southern California strawberry production showed that solarization had no effect on M. phaseolina and another warm season pathogen $F$. oxysporum f. sp. fragariae.

In Spain, biosolarization of fresh chicken manure and dried olive pomace provided significant reduction of $M$. phaseolina under warmer conditions than those observed in this study (Chamorro et al. 2015b, 2015a, Domínguez et al. 2014, 2016). Likewise, reductions in $M$. phaseolina populations were observed using anaerobic soil disinfestation, which is similar to biosolarization but with lower temperatures, in northern California strawberry production regions (Muramoto et al. 2016). In strawberry production in Turkey, M. phaseolina was effectively controlled by solarization (Yildiz et al. 2010). Even though sudangrass residues were used to enhance solarization in this experiment they likely would not help control $M$. phaseolina as sudangrass is susceptible to this pathogen. More research is needed to determine the efficacy of solarization, different organic amendments, and biosolarization against different strawberry pathogens. 
Yields of solarized treatments were much higher than non-solarized treatments primarily due to reduced pathogen populations in solarized treatments. Effects on yield are more than enough to justify solarization costs, which range between $\$ 865$ to $\$ 1975$ per hectare, depending on application method (Stapleton et al. 2008a). A significant yield increase over untreated plots is consistent with solarization treatments applied in strawberry production around the world (Iapichino et al. 2008, Rieger et al. 2001, Yildiz et al. 2010). However, in California the effects of solarization on yield have been variable with effects of solarization on yield varying from year to year (Daugovish et al. 2016, Hartz et al. 1993, Samtani et al. 2012). Additionally, in California strawberry production plants are growing for up to 10 months out of the year. This makes it challenging to fit a 4-8 weeks solarization period into a strawberry production system. The use of biosolarization could reduce the amount of time needed for solarization making its application more feasible (Stapleton et al. 2016). However, in this study, sudangrass treatments had no effect on increasing yield in solarized treatments. Due to the costs and time of sudangrass treatment, solarization alone may be the most cost-effective treatment for growers. Research into other organic amendments and shortening solarization application needs to be researched to increase adoption in California strawberry production systems.

\subsection{Conclusions}

Solarization was effective at reducing weed biomass between 49.8 and 95.2 percent during the first 3.5 months after tarp removal. Solarization also reduced $V$. dahliae populations by $80.7 \%$, reduced plant mortality by $54.9 \%$, and roughly tripled yields over non-solarized treatments indicating its potential for use in organic strawberry 
production along California's central coast. Solarization's effect on weed reduction disappeared after 3.5 months and solarized strawberries suffered some late season reduction in yields due to late season pathogens. Weed and disease reductions could be of more importance to shorter season crops particularly those with growing seasons less than 3 months. Testing solarization vs other organic soil disinfestation techniques can better inform growers on the advantages and disadvantages of each technique.

Additionally, it is important to determine the efficacy of solarization against different weeds and pathogens as sensitivity to heat differs between species. Sudangrass cover crops do not increase the impact of solarization. However, cover cropped treatments tended to perform better than non-cover cropped treatments. Cover crop mulch provided the best weed control and heathiest plants. Further research into cover crop mulches for organic strawberry production is warranted to verify reduction in weed population and improvements in plant health. 


\section{CHAPTER 4}

\section{GENERAL CONCLUSIONS}

A review of the literature on soil solarization showed that no alternative soil disinfestation technique has provided consistent weed/pathogen control, and economic returns comparable to chemical fumigation in central coast strawberry production. Although anaerobic soil disinfestation, soil steaming, and soil solarization/biosolarization have all been shown to increase yields to levels similar to chemical fumigation, each technique has limitations preventing wider adoption. To achieve effective weed and pathogen control in organic systems, alternative soil disinfestation techniques may need to be combined. Incorporating organic amendments before application of tarps, as used in biosolarization and anaerobic soil disinfestation, show the most promise for use in California strawberry production.

Laboratory experiments demonstrate that different weeds have different temperature and time requirements for thermal death to be achieved via solarization. Hard-seeded weed species showed high tolerance to simulated solarization temperatures. The lack of control of hard-seeded weeds by simulated solarization temperatures could be problematic for strawberry production, as hard-seeded weeds such as little mallow and redstem filaree survive fumigation, and as such may comprise a large part of the seed bank in previously fumigated strawberry fields. Other problematic weeds in strawberries, such as wind-blown Asteraceae weeds annual sowthistle and common groundsel, were easily controlled via simulated solarization temperatures.

In field experiment on solarization, weeds populations were reduced in solarized treatments when compared to non-solarized treatments for 3.5 months, allowing for effective strawberry establishment and reducing hand-weeding costs. Despite little 
mallow's tolerance to simulated solarization temperatures, solarized treatments showed reduction in little mallow populations up until 3.5 months after solarization. At 3.5 months after solarization little mallow populations were found at similar levels in solarized and non-solarized treatments. Solarization was also able to reduce $V$. dahliae populations by $80.7 \%$, reduce plant mortality by $54.9 \%$, and roughly tripled yields over non-solarized treatments indicating its potential for use in organic strawberry production in San Luis Obispo County strawberry production.

Mulched and incorporated sudangrass residues were tested in combination with solarization treatments to see if they increased the effects of solarization. Sudangrass residues did not increase the efficacy of solarization. However, mulched treatments provided better weed control and reduced plant mortality over incorporated and no sudangrass treatments. Further experiments on the effects of using sudangrass or other cover crop mulches need to be investigated in order to determine their potential for use in organic strawberry production to enhance weed control and potentially reduce disease severity. Additionally, studies on the mechanism for increased disease reduction by mulched residues over incorporated residues may be warranted if results can be repeated in other studies and are not due to lower pathogen loads in mulched treatments as may be the case in this study.

Other future areas of research regarding solarization can focus on finding thermal death thresholds and generating models for important strawberry pathogens and more weed species. Combining thermal death models of weeds and pathogens with temperature prediction models for soil solarization can help end users utilize solarization in their fields. 
Currently, anaerobic soil disinfestation and biosolarization appear to be the most economically feasible for organic strawberry growers. Therefore, researching the effects of different organic amendments incorporated under different tarps (clear, low-density polyethylene for solarization and virtually impermeable film for anaerobic soil disinfestation) under anaerobic conditions should be researched to maximize the efficacy of these techniques. Ultimately, developing long-term rotation guidelines using different integrated weed and pathogen thermal death models, organic amendments, crop rotations, and organic soil disinfestation techniques should be generated for organic growers on a regional basis. 


\section{REFERENCES}

Achmon Y, Harrold DR, Claypool JT, Stapleton JJ, VanderGheynst JS, Simmons CW (2016) Assessment of tomato and wine processing solid wastes as soil amendments for biosolarization. Waste Manag 48:156-164

Al-masoom AA, Saghir A, Itani S (1993) Soil solarization for weed management in U.A.E. Weed Technol 7:507-510

Anonymous (2003) A pest management strategic plan for strawberry production in California. $62 \mathrm{p}$

Anonymous (2019) California strawberry 2019 acreage survey. 14 p

Berbegal M, García-Jiménez J, Armengol J (2008) Effect of cauliflower residue amendments and soil solarization on Verticillium wilt control in artichoke. Plant Dis $92: 595-600$

Berlanger I, Powelson M (2005) Verticillium Wilt. Plant Heal Instr

Blok WJ, Lamers JG, Termorshuizen AJ, Bollen GJ (2000) Control of soilborne plant pathogens by incorporating fresh organic amendments followed by tarping. Phytopathology 90:253-259

Bolda M, Koike ST (2013) Verticillium wilt in strawberries: California update 2013. http://ucanr.edu/blogs/blogcore/postdetail.cfm?postnum=10993

Bolda M, Tourte L, Klonsky KM, Moura RL De, Tumber KP (2019) Sample costs to produce organic strawberries. University of California Cooperative Extension. $19 \mathrm{p}$

Bolda M, Tourte L, Murdock J, Sumner DA (2016) Sample costs to produce and harvest strawberries. $20 \mathrm{p}$

Budnik LT, Kloth S, Velasco-garrido M, Baur X (2012) Prostate cancer and toxicity from 
critical use exemptions of methyl bromide: Environmental protection helps protect against human health risks. Environ Heal 11:5

Butler DM, Kokalis-Burelle N, Muramoto J, Shennan C, McCollum TG, Rosskopf EN (2012) Impact of anaerobic soil disinfestation combined with soil solarization on plant-parasitic nematodes and introduced inoculum of soilborne plant pathogens in raised-bed vegetable production. Crop Prot 39:33-40

Candido V, D'addabbo T, Miccolis V, Castronuovo D (2011) Weed control and yield response of soil solarization with different plastic films in lettuce. Sci Hortic (Amsterdam) 130:491-497

Cantor A, Hale A, Aaron J, Traw MB, Kalisz S (2011) Low allelochemical concentrations detected in garlic mustard-invaded forest soils inhibit fungal growth and AMF spore germination. Biol Invasions 13:3015-3025

Carroll J, Pritts M, Heidenreich C (2016) Organic production and IPM guide for strawberries. Cornell University Cooperative Extension. $6 \mathrm{p}$

Carter CA, Chalfant JA, Goodhue RE, McKee GJ (2009) Costs of 2001 methyl bromide rules estimated for California strawberry industry. Calif Agric 59:41-46

Chamorro M, Domínguez P, Medina JJ, Miranda L, Soria C, Romero F, López Aranda JM, Daugovish O, Mertely J, De los Santos B (2015a) Assessment of chemical and biosolarization treatments for the control of Macrophomina phaseolina in strawberries. Sci Hortic (Amsterdam) 192:361-368 
Chamorro M, Miranda L, Domínguez P, Medina JJ, Soria C, Romero F, López Aranda JM, De los Santos B (2015b). Evaluation of biosolarization for the control of charcoal rot disease (Macrophomina phaseolina) in strawberry. Crop Prot 67:279 286

Coca MA, Almoguera C, Jordano J (1994) Expression of sunflower low-molecularweight heat-shock proteins during embryogenesis and persistence after germination: localization and possible functional implications. Plant Mol Biol 25:479-492

Coelho L, Mitchell DJ, Chellemi DO (2001) The effect of soil moisture and cabbage amendment on the thermoinactivation of Phytophthora nicotianae. Eur J Plant Pathol 107:883-894

Curto G, Dallavalle E, De Nicola GR, Lazzeri L (2012) Evaluation of the activity of dhurrin and sorghum towards Meloidogyne incognita. Nematology 16:759-769 Dahlquist-Willard RM, Marshall MN, Betts SL, Tuell-Todd CC, VanderGheynst JS, Stapleton JJ (2016) Development and validation of a Weibull-Arrhenius model to predict thermal inactivation of black mustard (Brassica nigra) seeds under fluctuating temperature regimens. Biosyst Eng 151:350-360

Dahlquist RM, Prather TS, Stapleton JJ (2007) Time and temperature requirements for weed seed thermal death. Weed Sci 55:619-625

Daugovish O, Howell A, Fennimore S, Koike S, Gordon T, Subbarao K (2016) Nonfumigant treatments and their combinations affect soil pathogens and strawberry performance in southern California. Int J Fruit Sci 16:37-46

Davis JR, Huisman OC, Westermann DT, Everson DO, Schneider A, Sorensen LH 
(2004) Some unique benefits with sudangrass for improved U.S. \#1 yields and size of Russet Burbank potato. Am J Potato Res 81:403-413

Dayan FE, Howell J, Weidenhamer JD (2009) Dynamic root exudation of sorgoleone and its in planta mechanism of action. J Exp Bot 60:2107-2117

Department of Pesticide Regulation (2016) Summary of pesticide use report data indexed by commodity. $782-789 \mathrm{p}$

DeVay JE, Stapleton JJ, Elmore CL (1991) Soil solarization. Proceedings of the First International Conference on Soil Solarization. Amman, Jordan: Rome FAO

Domínguez P, Miranda L, Medina JJ, de los Santos B, Talavera M, Daugovish O, Soria C, Chamorro M, López-Aranda JM (2016) Evaluation of non-fumigant alternative soil treatments for strawberry production in Huelva (Spain). Int J Fruit Sci 16:28-36

Domínguez P, Miranda L, Soria C, de los Santos B, Chamorro M, Romero F, Daugovish O, López-Aranda JM, Medina JJ (2014) Soil biosolarization for sustainable strawberry production. Agron Sustain Dev 34:821-829

Earlywine DT, Smeda RJ, Teuton TC, Sams CE, Earlywine DT, Smeda RJ, Teuton TC, Sams CE, Xiong X (2010) Evaluation of oriental mustard (Brassica juncea) seed meal for weed suppression in turf. Weed Technol 24:440-445

Ebihara Y, Uematsu S (2014) Survival of strawberry-pathogenic fungi Fusarium oxysporum f. sp. fragariae, Phytophthora cactorum and Verticillium dahliae under anaerobic conditions. J Gen Plant Pathol 80:50-58

Egley G (1990) High-temperature effects on germination and survival of weed seeds in soil. Weed Sci 38:429-435

El-Keblawy A, Al-Hamadi F (2009) Assessment of the differential response of weeds to 
soil solarization by two methods. Weed Biol Manag 9:72-78

Elmore CL, Roncoroni JA, Giraud DD (1993) Perennial weeds respond to control by soil solarization. Calif Agric:19-22

Elmore CL, Stapleton JJ, Bell CE (1997) Soil solarization: a nonpesticidal method for controlling diseases, nematodes, and weeds. University of California: Agriculture and Natural Resources. $17 \mathrm{p}$

Fennimore SA (2012) Weed control as part of soil disinfestation with fumigants and nonfumigants. Pages 118-123 in 2012 CWSS Proceedings. California Weed Science Society

Fennimore SA, Daugovish O, Bendixen W, Smith R (2018) UC IPM pest management guidelines: strawberry. University of California: Agriculture and Natural Resources.

Fennimore SA, Goodhue RE (2016) Soil disinfestation with steam: A review of economics, engineering, and soil pest control in California strawberry

Fennimore SA, Serohijos R, Samtani JB, Ajwa HA, Subbarao K V., Martin FN, Daugovish O, Legard D, Browne GT, Muramoto J, Shennan C, Klonsky K (2013) Tif film, substrates and nonfumigant soil disinfestation maintain fruit yields. Calif Agric 67:139-146

Fennimore SA, Street A, Martin FN, Ars U, Street EA, Miller TC, Street A, Broome JC, Associates DS, Way S, Greene I, Boulevard A (2014) Evaluation of a mobile steam applicator for soil disinfestation in California strawberry. HortScience 49:15421549

Gamliel A, Austerweil M, Kritzman G (2000) Non-chemical approach to soilborne pest management - organic amendments. Crop Prot 19:847-853 
Gamliel A, Katan J (2012) Soil solarization: Theory and practice. St. Paul, Minnesota: APS Press/The American Phytopathological Society

Gamliel A, Stapleton JJ (1993a) Effect of chicken compost or ammonium phosphate and solarization on pathogen control, rhizosphere microorganisms, and lettuce growth. Plant Dis 77:886-891

Gamliel A, Stapleton JJ (1993b) Characterization of antifungal volatile compounds evolved from solarized soil amended with cabbage residues. Phytopathology 83:899-905

García-Méndez E, García-Sinovas D, Becerril M, De Cal A, Melgarejo P, MartínezTreceño A, Fennimore SA, Soria C, Medina JJ, López-Aranda JM (2008) Chemical alternatives to methyl bromide for weed control and runner plant production in strawberry nurseries. HortScience 43:177-182

Gorder N, Lee M, Fossen M, Verke P, Davidson N (2013) Nonfumigant strawberry production working group action plan. $40 \mathrm{p}$

Guthman J (2017) Land access and costs may drive strawberry growers' increased use of fumigation. Calif Agric 71:1-8

Harris DC, Yang JR (1996) The relationship between the amount of Verticillium dahliae in soil and the incidence of strawberry wilt as a basis for disease risk prediction:106-114

Hartz TK, DeVay JE, Elmore CL (1993) Solarization is an effective soil disinfestation technique for strawberry production. HortScience 28:104-106

Horowitz M, Regev Y, Herzlinger G (1983) Solarization for weed control. Weed Sci $31: 170-179$ 
Horowitz M, Taylorson RB (1983) Effect of high temperatures on imbibition, germination, and thermal death of velvetleaf (Abutilon threophrasti) seeds. Can J Bot 61:2269-2276

Hoyle JA, Mcelroy JS (2012) Relationship between temperature and heat duration on large crabgrass (Digitaria sanguinalis), virginia buttonweed (Diodia virginiana), and cock's-comb kyllinga (Kyllinga squamulata) seed mortality. Weed Technol 26:800-806

Iapichino G, Prinzivalli C, D’Anna F (2008) Soil solarization as an alternative to methyl bromide fumigation for annual strawberry production in a mediterranean area. J Sustain Agric 32:365-375

Kabir Z, Bhat RG, Subbarao K V. (2007) Comparison of media for recovery of Verticillium dahliae from soil. Plant Dis 88:49-55

Kanaan H, Medina S, Krassnovsky A, Raviv M (2015) Survival of Macrophomina phaseolina and Verticillium dahliae during solarization as affected by composts of various maturities. Crop Prot 76:108-113

Klosterman SJ, Atallah ZK, Vallad GE, Subbarao K V (2009) Diversity, pathogenicity, and management of Verticillium species. Annu Rev Phytopathol 47:39-62

Koike ST, Bull CT, Bolda M, Daugovish O (2012) Organic Strawberry Production Manual. University of California: Agriculture and Natural Resources. 160 p Korthals GW, Thoden TC, van den Berg W, Visser JHM (2014) Long-term effects of eight soil health treatments to control plant-parasitic nematodes and Verticillium dahliae in agro-ecosystems. Appl Soil Ecol 76:112-123

Larson KD, Shaw D V (2000) Soil fumigation and runner plant production : A synthesis 
of four years of strawberry nursery field trials. HortScience 35:642-646

Van Loenen MCA Van, Turbett Y, Mullins CE, Feilden NEH, Wilson MJ, Leifert C, Seel WE (2003) Low temperature - short duration steaming of soil kills soil-borne pathogens, nematode pests and weeds. Eur J Plant Pathol 109:993-1002

Lopez-Escudero FJ, Blanco-Lopez MA (2001) Effect of a single or double soil solarization to control Verticillium wilt in established olive orchards in Spain. Plant Dis 85:489-496

MacGuidwin AE, Knuteson DL, Connell T, Bland WL, Bartelt KD (2012) Manipulating inoculum densities of Verticillium dahliae and Pratylenchus penetrans with green manure amendments and solarization influence potato yield. Phytopathology 102:519-527

Marenco RA, Lustosa DC (2000) Soil solarization for weed control in carrot. Pesqui Agropecu Bras 35:2025-2032

Marshall MN, Rumsey TR, Stapleton JJ, Vandergheynst JS (2013) A predictive model for soil temperature during solarization and model validation at two California field sites. Trans ASABE 56:117-133

Matheron ME, Porchas M (2010) Evaluation of soil solarization and flooding as management tools for Fusarium wilt of lettuce. Plant Dis 94:1323-1328

Mauromicale G, Monaco A Lo, Longo AMG, Restuccia A (2005) Soil solarization, a nonchemical method to control branched broomrape (Orobanche ramosa) and improve the yield of greenhouse tomato. Weed Sci 53:877-883

Mazzola M, Agostini A, Cohen MF (2017) Incorporation of Brassica seed meal soil amendment and wheat cultivation for control of Macrophomina phaseolina in 
strawberry. Eur J Plant Pathol 149:57-71

Mazzola M, Muramoto J, Shennan C (2018) Anaerobic disinfestation induced changes to the soil microbiome, disease incidence and strawberry fruit yields in California field trials. Appl Soil Ecol 127:74-86

Medina C, Cardemil L (1993) Prosopis chilensis is a plant highly tolerant to heat shock. Plant Cell Environ 16:305-310

Melander B, Jørgensen MH (2005) Soil steaming to reduce intrarow weed seedling emergence. Weed Res 45:202-211

Melander B, Kristensen JK (2011) Soil steaming effects on weed seedling emergence under the influence of soil type, soil moisture, soil structure and heat duration. Ann Appl Biol 158:194-203

Meyer SLF, Asada IA, Risajo SB, Orra MJ (2011) Mustard seed meal mixtures: Management of Meloidogyne incognita on pepper and potential phytotoxicity. $\mathrm{J}$ Nematol 43:7-15

Moravcova L, Dostalek J (1989) Contribution to the biology of germination of four species of Chenopodium album agg. under different condition. Folia Geobot Phytotaxon 24:431-439

Motisi N, Doré T, Lucas P, Montfort F (2010) Dealing with the variability in biofumigation efficacy through an epidemiological framework. Soil Biol Biochem 42:2044-2057

Muramoto J, Shennan C, Zavatta M, Baird G, Toyama L, Mazzola M (2016) Effect of anaerobic soil disinfestation and mustard seed meal for control of charcoal rot in California strawberries. Int J Fruit Sci 16:59-70 
Nagelkerke NJD (1991) A note on a general definition of the coefficient of determination. Biometrika 78:691-692

De Nicola GR, Leoni O, Malaguti L, Bernardi R, Lazzeri L (2011) A simple analytical method for dhurrin content evaluation in cyanogenic plants for their utilization in fodder and biofumigation. J Agric Food Chem 59:8065-8069

Núñez-zofío M, Larregla S, Garbisu C (2011) Application of organic amendments followed by soil plastic mulching reduces the incidence of Phytophthora capsici in pepper crops under temperate climate. Crop Prot 30:1563-1572

Nyczepir AP, Rodriguez-Kabana R (2007) Preplant biofumigation with sorghum or methyl bromide compared for managing Criconemoides xenoplax in a young peach orchard. Plant Dis 91:1607-1611

Ochiai N, Powelson ML, Crowe FJ, Dick RP (2008) Green manure effects on soil quality in relation to suppression of Verticillium wilt of potatoes. Biol Fertil Soils 44:10131023

Patrício FRA, Sinigaglia C, Barros BC, Freitas SS, Neto JT, Cantarella H, Ghini R (2006) Solarization and fungicides for the control of drop, bottom rot and weeds in lettuce. Crop Prot 25:31-38

Peachey ARE, Pinkerton JN, Ivors KL, Miller ML, Moore LW (2001) Effect of soil solarization, over crops, and metham on field emergence and survival of buried annual bluegrass (Poa annua). Weed Technol 15:81-88

Pinkerton JN, Ivors KL, Miller ML, Moore LW (2000) Effect of soil solarization and cover crops on populations of selected soilborne plant pathogens in western Oregon. Plant Dis 84:952-960 
Pinkerton JN, Ivors KL, Reeser PW, Bristow PR, Windom GE (2002) The use of soil solarization for the management of soilborne plant pathogens in strawberry and red raspberry production. Plant Dis $86: 645-651$

Porter IJ, Merriman PR (1983) Effects of solarization of soil on nematode and fungal pathogens at two sites in Victoria. Soil Biol Biochem 15:39-44

Powles SB, Charman N, Poole F (1988) Solar Heating (solarization) of the soil surface: effect on weed control, and yield of Phaseolus vulgaris. Plant Prot Q 3:31-35

Pullman GS, DeVay JE, Garber RH (1981a) Soil solarization and thermal death: A logarithmic relationship between time and temperature for four soilborne plant pathogens. Phytopathology 71:959-964

Pullman GS, DeVay JE, Garber RH, Weinhold AR (1981b) Soil solarization: Effects on Verticillium wilt of cotton and soilborne populations of Verticillium dahliae, Pythium spp., Rhizoctonia solani, and Thielaviopsis basicola. Phytopathology 71:954-959

Rieger M, Krewer G, Lewis P (2001) Solarization and chemical alternatives to methyl bromide for preplant soil treatment of strawberries. Horttechnology 11:258-264

Rosskopf E, Kokalis-Burelle N, Butler D (2010) Development of anaerobic soil disinfestation for Florida vegetable and flower production. Page 84 in Annual International Research Conference on Methyl Bromide Alternatives and Emissions Reductions. Orlando, FL, USA

Rubin B, Benjamin A (1984) Solar heating of the soil: Involvement of environmental factors in the weed control process. Weed Sci 32:138-142

Samtani JB, Ajwa HA, Weber JB, Browne GT, Klose S, Hunzie J, Fennimore SA (2011) 
Evaluation of non-fumigant alternatives to methyl bromide for weed control and crop yield in California strawberries (Fragaria ananassa L.). Crop Prot 30:45-51

Samtani JB, Gilbert C, Ben Weber J, Subbarao K V., Goodhue RE, Fennimore SA (2012) Effect of steam and solarization treatments on pest control, strawberry yield, and economic returns relative to methyl bromide fumigation. HortScience 47:64-70

Shennan C, Muramoto J, Koike S, Baird G, Fennimore S, Samtani J (2018) Anaerobic soil disinfestation is an alternative to soil fumigation for control of some soilborne pathogens in strawberry production. Plant Pathol 67:51-66

Simmons CW, Guo H, Claypool JT, Marshall MN, Perano KM, Stapleton JJ, VanderGheynst JS (2013) Managing compost stability and amendment to soil to enhance soil heating during soil solarization. Waste Manag 33:1090-1096

Simmons CW, Higgins B, Staley S, Joh LD, Simmons BA, Singer SW, Stapleton JJ, VanderGheynst JS (2016) The role of organic matter amendment level on soil heating, organic acid accumulation, and development of bacterial communities in solarized soil. Appl Soil Ecol 106:37-46

Stapleton JJ (1996) Fumigation and solarization practice in plasticulture systems. Horttechnology 6:189-192

Stapleton JJ, Dahlquist-willard RM, Achmon Y, Marshall MN, Jean S, Simmons CW (2016) Advances in biosolarization technology to improve soil health and organic control of soilborne pests. Pages 1-6 in Organic Agricuture Research Symposium. Pacific Grove, CA, USA

Stapleton JJ, DeVay JE (1986) Soil solarization: a non-chemical approach for management of plant pathogens and pests. Crop Prot 5:190-198 
Stapleton JJ, Molinar RH, Lynn-Patterson K, McFeeters SK, Shrestha A (2008a) Methyl bromide alternatives ... Soil solarization provides weed control for limited-resource and organic growers in warmer climates. Calif Agric 59:84-89

Stapleton JJ, Summers CG, Mitchell JP, Prather TS (2010) Deleterious activity of cultivated grasses (Poaceae) and residues on soilborne fungal, nematode and weed pests. Phytoparasitica 38:61-69

Stapleton JJ, Wilen CA, Molinar RH (2008b) Soil solarization for gardens and landscapes. University of California: Agriculture and Natural Resources. 4 p.

Steinmaus S, Walter V (2002) Solarization as an effective soil disinfestation alternative with open/moving roof structure used for cut flowers. $7 \mathrm{p}$

Steinmaus S, Walter V (2003) Solarization as an effective soil disinfestation alternative with open/moving roof structure used for cut flowers. $4 \mathrm{p}$

Tamietti G, Valentino D (2001) Soil solarization: A useful tool for control of Verticillium wilt and weeds in eggplant crops under plastic in the Po valley. J Plant Pathol $83: 173-180$

Tjamos EC, Fravel DR (1995) Detrimental effects of sublethal heating and Talaromyces flavus on microsclerotia of Verticillium dahliae

Tourte L, Bolda M, Klonsky K (2016) The evolving fresh market berry industry in Santa Cruz and Monterey counties. Calif Agric 70:107-115

UNEP (2001) Alternatives to methyl bromide: Sourcebook of technologies for protecting the ozone layer. $329 \mathrm{p}$

US EPA (1998) R.E.D. facts 1,3-Dichoropropene. 1-9 p 
US EPA (2000) Methyl bromide (bromomethane). https://www.epa.gov/haps/healtheffects-notebook-hazardous-air-pollutants

US EPA (2008) Reregistration eligibility decision (RED) for chloropicrin. 1-127 p

US EPA (2019) Methyl bromide. https://www.epa.gov/ods-phaseout/methyl-bromide

Webster TM (2003) High temperatures and durations of exposure reduce nutsedge (Cyperus spp.) tuber viability. Weed Sci 51:1010-1015

Weston LA, Alsaadawi IS, Baerson SR (2013) Sorghum allelopathy-From ecosystem to molecule. J Chem Ecol 39:142-153

Widmer TL, Abawi GS (2000) Mechanism of suppression of Meloidogyne hapla and its damage by a green manure of sudangrass. Plant Dis $84: 562-568$

Widmer TL, Abawi GS (2002) Relationship between levels of cyanide in sudangrass hybrids incorporated into soil and suppression of Meloidogyne hapla. J Nematol $34: 16-22$

Wiggins BE, Kinkel LL (2004) Green manures and crop sequences influence potato diseases and pathogen inhibitory activity of indigenous streptomycetes. Phytopathology 95:178-185

Wilhelm S, Storkan RS, Wilhelm JI (1974) Preplant soil fumigation with methyl bromide-choropicrin mixtures for control of soil-borne diseases of strawberries- A summary of fifteen years of development. Agric Environ 1:227-236

Wu JY, Dastgheib F (2001) Effects of various herbicides and surfactants on mallow (Malva spp.). Pages 589-593 in Proceedings of the 18th Asian-Pacific Weed Science Society Conference. Beijing, China: Asian-Pacific Weed Science Society 
Yildiz A, Benlioğlu S, Boz Ö, Benlioğlu K (2010) Use of different plastics for soil solarization in strawberry growth and time-temperature relationships for the control of Macrophomina phaseolina and weeds. Phytoparasitica 38:463-473

Youssef MMA (2015) Biofumigation as a promising tool for managing plant parasitic nematodes. A review. Sci Agric 10:115-118

Zavatta M, Shennan C, Muramoto J, Baird G, Boida MP, Koike ST, Klonsky K (2014) Integrated rotation systems for soilborne disease, weed, and fertility management in strawberry/vegetable production. Acta Hortic 1044:269-274 


\section{APPENDICES}

\section{Appendix A}

Research Design and Field Information

\begin{tabular}{|l|l|l|l|l|l|}
\multicolumn{1}{l}{ Mulched } & No Sudangrass & Incorporated & No Sudangrass & \multicolumn{2}{c}{ Incorporated } \\
S & S & NS & NS & S & S \\
\hline NS & NS & S & S & NS & NS \\
\hline
\end{tabular}

\begin{tabular}{|c|c|c|c|c|c|}
\hline Mulched & No Sudangrass & Incorporated & Mulched & Incorporated & No Sudangrass \\
\hline NS & S & NS & S & NS & NS \\
\hline $\mathrm{n} / \mathrm{a}$ & NS & S & NS & S & S \\
\hline
\end{tabular}

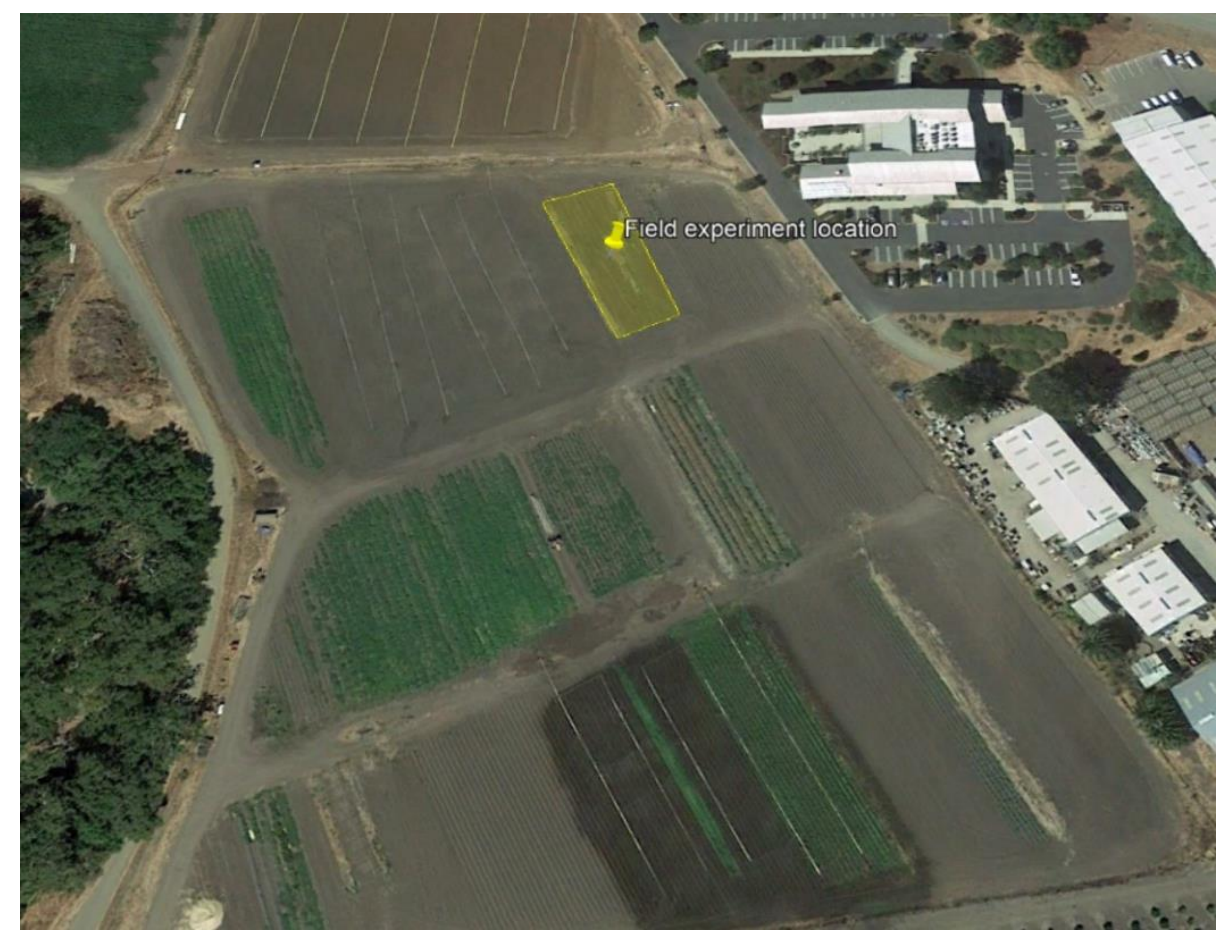

Figure A.1: Plot Layout of Field Experiment (Top). S=Solarized and NS=Non-Solarized. Location of Field Experiment on Cal Poly Organic Farm (Bottom) (35'18’16.90” N 120 40’19.83” W). 
Table A.1:Weather Data from CIMIS Station 52 Located on Cal Poly San Luis Obispo Campus from May 2018 to June 2019.

\begin{tabular}{|c|c|c|c|c|c|c|}
\hline $\begin{array}{l}\text { Month } \\
\text { Year }\end{array}$ & $\begin{array}{l}\text { Total } \\
\text { Precip } \\
\text { (in) }\end{array}$ & $\begin{array}{l}\text { Avg Sol } \\
\text { Rad } \\
\text { (Ly/day) }\end{array}$ & $\begin{array}{c}\text { Avg } \\
\text { Max Air } \\
\text { Temp } \\
\left({ }^{\circ} \mathrm{F}\right)\end{array}$ & $\begin{array}{c}\text { Avg Min } \\
\text { Air } \\
\text { Temp } \\
\left({ }^{\circ} \mathrm{F}\right)\end{array}$ & $\begin{array}{c}\text { Avg Air } \\
\text { Temp }\end{array}$ & $\begin{array}{c}\text { Avg Soil } \\
\text { Temp }\end{array}$ \\
\hline May-18 & 0.01 & 516 & 75.8 & 52.3 & 61.1 & 64.7 \\
\hline Jun-18 & 0 & 594 & 84 & 55.3 & 66.3 & 67.6 \\
\hline Jul-18 & 0 & 563 & 89.5 & 59.2 & 69.5 & 71.3 \\
\hline Aug-18 & 0 & 534 & 87.2 & 58.6 & 70.1 & 71.5 \\
\hline Sep-18 & 0 & 462 & 87.7 & 56.1 & 67.4 & 69.2 \\
\hline Oct-18 & 0.64 & 368 & 78.2 & 51.9 & 63.1 & 66.1 \\
\hline Nov-18 & 4.55 & 278 & 74 & 48.5 & 60.1 & 60.9 \\
\hline Dec-18 & 1.07 & 227 & 63.8 & 46.1 & 54.5 & 56.8 \\
\hline Jan-19 & 6.91 & 216 & 64 & 45.7 & 54.4 & 55.2 \\
\hline Feb-19 & 7.48 & 284 & 57.9 & 40 & 48.8 & 53.3 \\
\hline Mar-19 & 6.17 & 403 & 64.8 & 45.7 & 54.6 & 56.9 \\
\hline Apr-19 & 0.19 & 500 & 69 & 49.1 & 58.1 & 62.2 \\
\hline May-19 & 1.75 & 523 & 66.6 & 49.9 & 57.1 & 64.5 \\
\hline Jun-19 & 0 & 614 & 73.5 & 54.2 & 62 & 68.8 \\
\hline
\end{tabular}

